University of Nebraska - Lincoln DigitalCommons@University of Nebraska - Lincoln

Zea E-Books

Zea E-Books

$10-25-2016$

\title{
The Year-Long Adventures of the Blue Shoes \& Their Friends
}

Michael R. Hill

michaelhilltemporary1@yahoo.com

Follow this and additional works at: http://digitalcommons.unl.edu/zeabook

Part of the Digital Humanities Commons, Industrial and Product Design Commons, Interactive $\underline{\text { Arts Commons, Interdisciplinary Arts and Media Commons, and the Photography Commons }}$

\section{Recommended Citation}

Hill, Michael R., "The Year-Long Adventures of the Blue Shoes \& Their Friends" (2016). Zea E-Books. Book 49.

http://digitalcommons.unl.edu/zeabook/49

This Book is brought to you for free and open access by the Zea E-Books at DigitalCommons@University of Nebraska - Lincoln. It has been accepted for inclusion in Zea E-Books by an authorized administrator of DigitalCommons@University of Nebraska - Lincoln. 


\section{THE YEAR-LONG ADVENTURES OF THE BLUE SHOES \& THEIR FRIENDS}

\section{A Pedagogical Experiment in Visual Blogging and Tutoring University Athletes at the University of Nebraska-Lincoln}

\section{MICHAEL R. HILL}

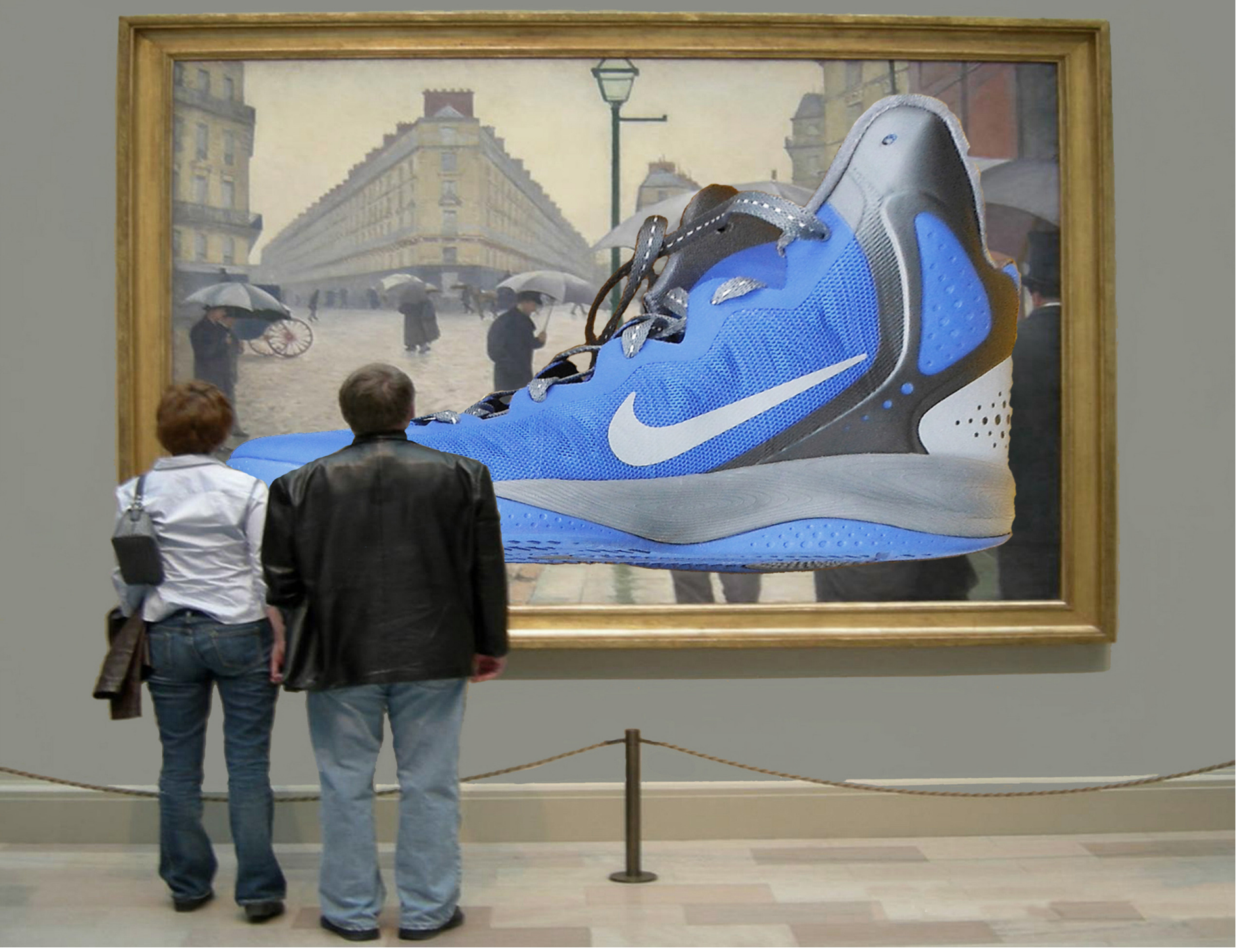





\title{
THE YEAR-LONG ADVENTURES OF THE
} BLUE SHOES

\author{
\& \\ THEIR \\ FRIENDS
}




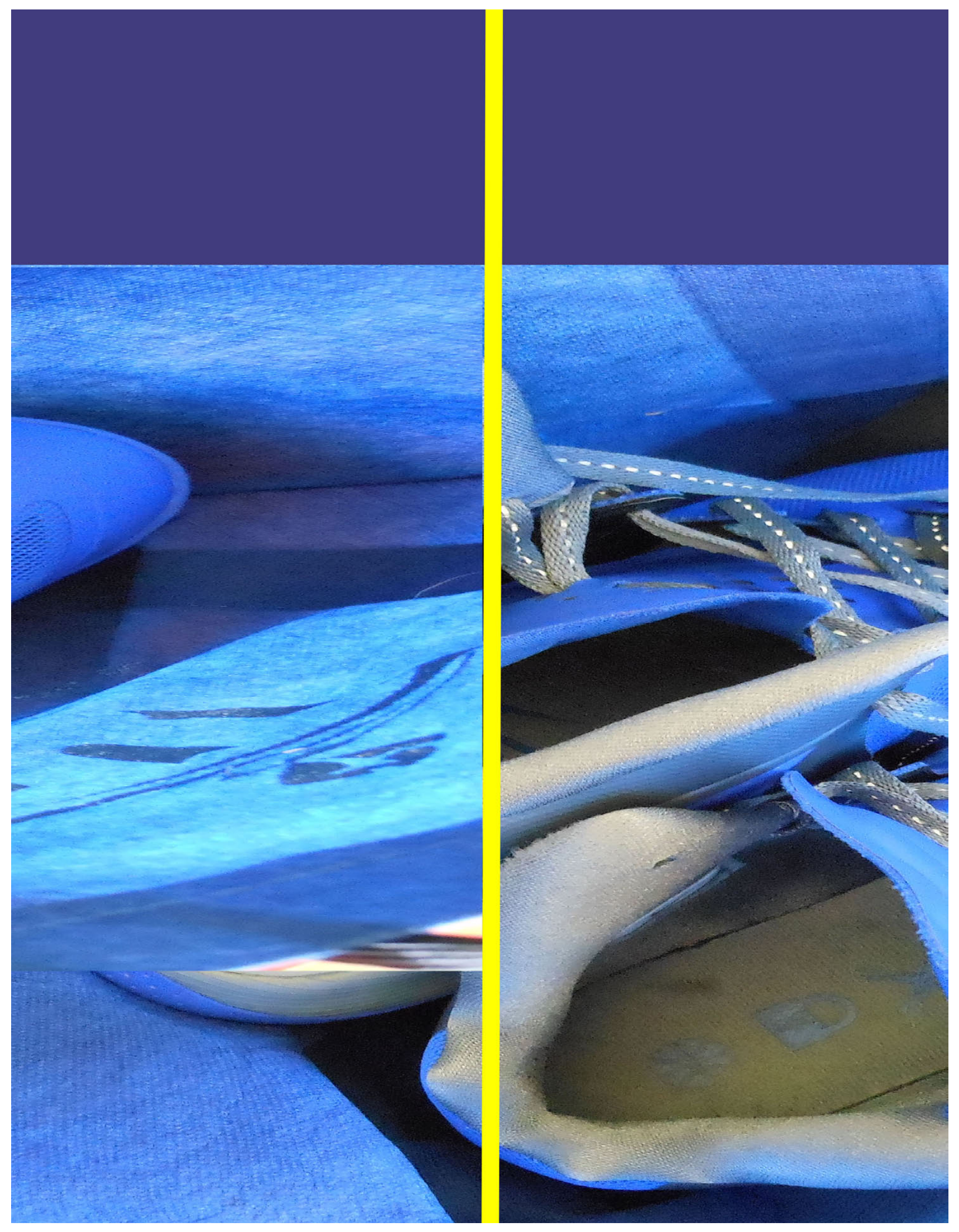




\title{
THE YEAR-LONG ADVENTURES OF THE BLUE SHOES \& THEIR FRIENDS
}

\author{
A Pedagogical Experiment in Visual Blogging \\ and Tutoring University Athletes \\ at the University of Nebraska-Lincoln
}

\section{Michael R. Hill \\ University of Nebraska-Lincoln}

With 52 Color Plates \& Related Illustrations

Foreword by Georgina VAlVERde Art Institute of Chicago 
(c) Copyright 2016 by Michael R. Hill

Uncaptioned photographs/collages by Michael R. Hill:

Front Cover: Day 77 - Gallery Dream, Art Institute of Chicago

Back Cover: Day 88 - Gargoyle Dream, Cobb Gate, University of Chicago

Half Title: The Blue Shoes

Frontispiece: Day 216 - Abstraction, No. 4

Page vi: The Blue Shoes

Page viii: Day 218 - Abstraction, No. 6

Page 9: Day 217 - Abstraction, No. 5

Page 10: SHOE, Pattern Study

Page 66: Share the Road, Fermilab, Batavia, Illinois

Page 68: Portico, Art Institute of Chicago

Page 78: Day 320 - Random Quadrats, Surrealism Series, No. 4 (constructed with the aid of a random numbers table)

Page 80: Day 140 - Still Life, No. 18

Book design: Michael R. Hill

The text is set in Adobe Hypatia Sans Pro

ISBN 978-1-60962-105-6

doi $10.13014 / K 26 Q 1 V 54$

Zea Books are published by the University of Nebraska-Lincoln Libraries Electronic (pdf) edition available online at http://digitalcommons.unl.edu

Print edition available from http://www.lulu.com/spotlight/unlib

UNL does not discriminate based upon any protected status.

Please go to unl.edu/nondiscrimination

Nebraskina

Lincoln 
This book is dedicated with admiration \& gratitude to

\section{KIM SCHELLPEPER}

patient mentor, cheerful friend, supportive colleague 


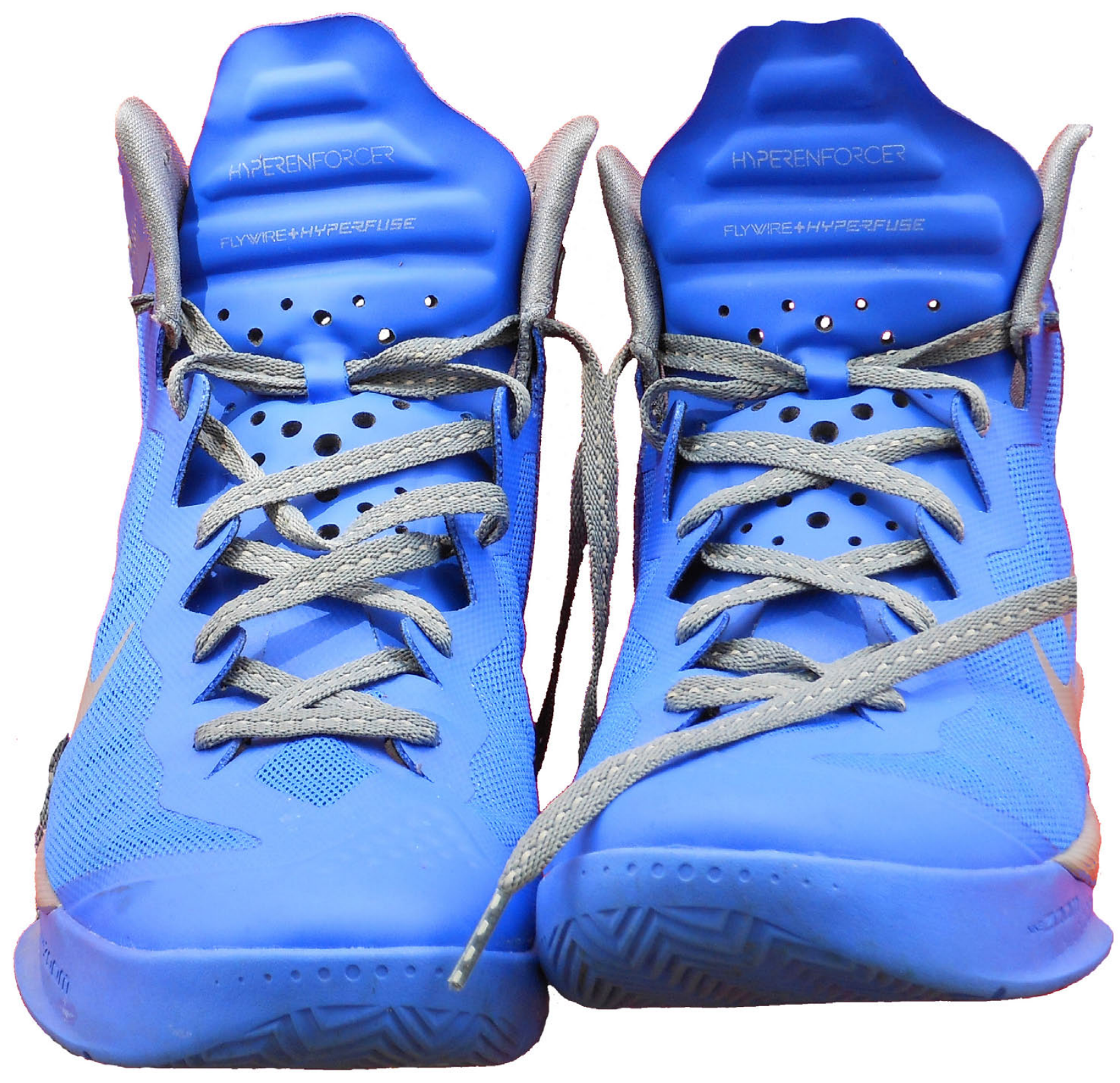




\section{CONTENTS}

Preface vii

Acknowledgments $\ldots \ldots \ldots \ldots \ldots \ldots \ldots \ldots \ldots \ldots \ldots \ldots \ldots \ldots \ldots \ldots$ viii

Foreword: The Adventures of the Blue Shoes - A Journey of Self-Transformation

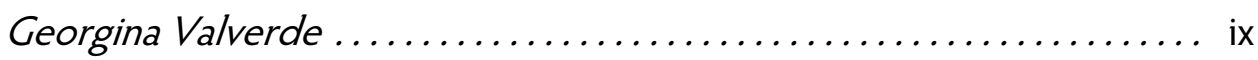

The Year-Long Adventures of the Blue Shoes \& Their Friends: An Experiment in Visual Blogging and Tutoring Student-Athletes at the University of Nebraska-Lincoln Michael R. Hill. . . . . . . . . . . . . . . . . . . . . . . . . . . . . . . . . . . . 1

The Plates: 52 Selected Posts from the Visual Blog ................. 9

Notes on Sources for the Plates............................. 67

Appendix I: Lesson Plan — My Favorite Shoes in Words and a Picture ....... 69

Appendix II: An Exemplary Student Essay . . . . . . . . . . . . . . . . . . . 77

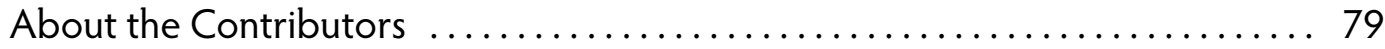




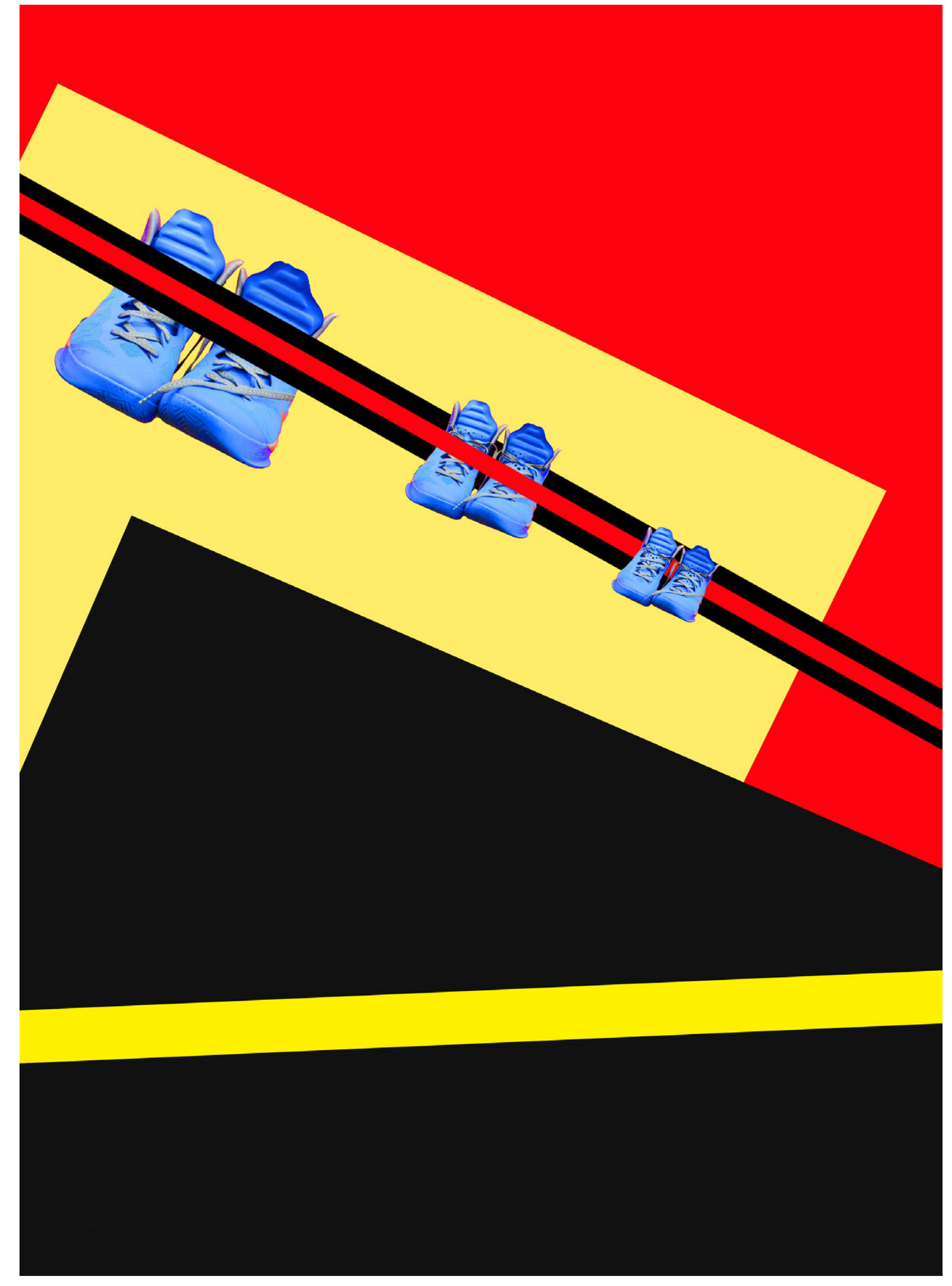




\section{Preface}

For 365 consecutive days, from August 1, 2013 to July 31, 2014, I posted a daily digital image to a "visual blog" that always featured, however tangentially, some aspect of one or more athletic shoes. The project began as a pedagogical ploy, instigated during a Teacher Workshop at the Art Institute of Chicago and utilized in my tutoring of student athletes at the University of Nebraska-Lincoln, but it morphed - for me - into something more: a disciplined personal journey of graphic invention. This book reflects both dimensions of the "Blue Shoes" project: (a) the pedagogical and practical, through inclusion of a formal lesson plan (Appendix I) and an example student essay (Appendix II) and (b) my artistic journey, via 52 color plates chronologically selected from the full set of 365 graphic online posts. The project as a whole is outlined in Georgina Valverde's gracious foreword and my brief introductory essay. I invite you to join me in this retrospective look at "The Year-Long Adventures of the Blue Shoes and Their Friends," and I hope that some of you will conceptualize and commit to undertaking your own 365-day project - be it visual, written, musical or some combination thereof - and posting the results/discoveries/insights online in daily installments. 


\section{ACKNOWLEDGMENTS}

Thanks are due many people who directly, indirectly, or unwittingly inspired or encouraged this project at various stages from before its inception, through its realization and evolution, to the making of this book, including: Georgina Valverde, Cheryl Pope, and Mark Krisco at the Art Institute of Chicago; The hard-working staff and students at the University of Nebraska-Lincoln's Hewit Center, especially: Dennis Leblanc, Kim Schellpeper, Alvin Banks, Andrea Einspahr, Sheri Hastings, Katie Jewell, Mike Niemann, Caleb Hawley, Leah Huber,Joanne Ross,Jan Walkenhorst, Tay Hester, Kylee Muir, and Jonathan Rose; The irrepressible free spirits of the Krasl Art Center: Julia Gourley, Tami Miller, Nathan Margoni, Sheri Baun, Kyah Culp, Jackie Kenyon (now at the Box Factory for the Arts), Adam Kuehl, Keith Stevens, Galina Morrissett, Marion Huyck, Anita Rutlin, Cindy Jakeway, Joann Sprayberry, Ann Wilschke, Leslie Wood, and Bob Sachtleben; the PechaKucha organizers in Benton Harbor-St.Joseph; Paul Royster at Zea Books; Matt Stone at Sandbox Studio; A host of unsung clerks at Nike's factory outlet stores in Williamsburg (lowa) and Michigan City (Indiana); The magnificent Mizpah Park trio: Tyli, Bella, and Maxine (and their amazing parents: Mary Ellen, Andy, Ron, Cyd, and Pete); and many other long-standing friends, especially: Paula and Thomas Van Eenenaam, Marcia and Steve Watson, Sylvia Zhang, Joshua Meeks, Deb and Dave Andersen, Tom Carr, June and Dave Bilyeu, Lori Ratzlaff, Julia McQuillan, Deb Logan, Ross Hecht, Morrie Tuttle, Rollin Davis, Richard Potts, Richard Kennedy, Sally and Bob Stoddard, Michelle Kitzrow and the Tooth Patrol, and, most crucially, my life-partner, Mary Jo Deegan.

My photographs of my personal footwear do not constitute, represent, or imply endorsement of any brand of athletic apparel on the part of tumblr.com, PechaKucha, the Art Institute of Chicago, the Krasl Art Center, the University of Nebraska-Lincoln, or their employees or students. The images reproduced in this work are provided solely with pedagogical, educational, artistic, and creative intent. 
FOREWORD:

The Adventures of the Blue Shoes - A Journey

of Self-Transformation

GeORGina VALVERDE

In the summer of 2013, Michael Hill took a simple but bold step: after attending a workshop on Impressionism and fashion that I organized at the Art Institute of Chicago, he decided to start a visual blog documenting the daily travels of a pair of blue sneakers.

Michael's initial goal was to further a pedagogical approach he uses to bridge cultural differences between him and his students (who are mostly athletes) and introduce subject matter for their writing. His strategy consists of wearing colorful designer sneakers to help spark conversations and encourage students' leap into academics by taking as their point of departure a familiar object that is central to their identity. The practice of this strategy has led Michael to amass an extraordinary collection of athletic shoes. On the day of the workshop, Michael wore a pair of blue Nike Hyperenforcers. Little did he know what lay ahead.

Michael embarked on his 365-day blogging adventure unaware of what would ultimately happen: his transformation from a "teacher/scholar" to an "artist." What began as an extension of his pedagogy ultimately resulted in self-transformation through art. Through The Blue Shoes project, Michael found his artistic voice.

The achievement of voice in the arts is well understood — even the lay public has an appreciation of its importance. Artistic voice is an individual achievement. We don't expect artists to attain a standard voice; quite the contrary, the point is the development of individuality. Artistic voice is the result of self-experimentation and grappling with the tension between personal and social experience. Voice then is inherently paradoxical because it must assert itself against the shaping forces of culture. In a sense, voice is about defiance and a commitment to self-realization. Encouraging students to strike out in the pursuit of their own voice should be one of 
the central goals of education, but this project of individuation stands in stark contrast with the larger agenda of mass education: the socialization of the individual. Instead of being about a journey of self-discovery, education is often about conforming, standardizing, and fitting in.

In The Hero with a Thousand Faces, mythologist Joseph Campbell introduces the idea of the monomyth or the hero's journey - the journey of an archetypal hero that frequently appears in many mythologies around the world. Through the journey, the hero is changed; he or she rises from anonymity and emerges as a subject with individual attributes and contributions. The journey consists roughly of three main stages: heeding the call to adventure or withdrawal from ordinary reality; the journey itself, fraught with trials and tasks that the hero must accomplish alone or with minimal help; and finally, a reincorporation into the world after achieving a transformed consciousness, the product of the journey. This journey is similar to the creative process, which includes an initial struggle as the artist sets out to investigate and give shape to new experiences or concerns - a struggle that often leads to breakthroughs and transformation.

The hero's journey gives us a powerful image for education as a journey of growth and transformation. Framing education as a hero's journey allows us to see it as the adventure into the unknown that it is: there is no charted path or guarantee of success when we venture out into unfamiliar ground, there is no frame of reference - we just have to plunge in. The image of the hero's journey also underlines the agency of the learner in the performance of his or her own cognitive transformation - it foregrounds that what is at stake in education is the emergence of voice and subjectivity, i.e. the emergence of multiple possible selves and our agency to choose which to shape. ${ }^{1}$

Michael's journey began with his first post about The Blue Shoes. His quest was guided by a simple question, "What if I place the blue shoes in whatever place I

\footnotetext{
${ }^{1}$ I want to acknowledge my friend and mentor, Joe Becker, for introducing me to his ideas on the journey and the blind leap. Joe Becker is Associate Professor Emeritus at the University of Illinois at Chicago's Department of Educational Psychology.
}

xii 
happen to be?" As he grappled with the initial awkwardness of placing the blue shoes in different public spaces, he began to establish a new relationship with the world. Initially, he felt uncomfortable and self-conscious. His actions also unsettled and bewildered a number of strangers that witnessed him photographing the shoes. Soon, he overcame awkwardness and learned to navigate this new territory, and his new sense of confidence led to a freer investigation of his initial question.

Restlessness, tentativeness, and insecurity are part of every artist's journey into the unknown. We question whether we are doing the right thing heeding our hunches, whether others will approve or reject our ideas, whether we will be understood. We experience frustration at having to answer these questions by ourselves, at not having a map to point the way and take uncertainty out of the journey. Students in school also experience these disorienting feelings as they struggle to understand new concepts. Sadly, we are not comfortable with anything short of success and clarity in education. We look for foolproof curricula, we strive to remove all difficulty by "scaffolding" and predetermining learning outcomes, we establish standards and measurements, and we prescribe. In the process, we instill self-doubt. We end up with students who look outside of themselves for direction and validation; who dare not question authority, let alone strike out on their own passionate journey.

After experimenting with The Blue Shoesfor forty days, Michael heeded a soft stirring. "Largely on a whim," he tells us, he decided to revisit the first Blue Shoes post. This whim shows us voice at work. Voice whispers and nudges - as we heed its provocations we also nurture and strengthen our intuition and learn to trust ourselves. When Michael returned to the first post on The Blue Shoes, he discovered that he was not the same amateur photographer that had begun the blog — he had evolved. The daily ritual of posting an image had prompted a slight cognitive shift. Placing the shoes in a public space and taking a photograph was no longer satisfying, so he began to push his skills in digital imaging. At this juncture, he began his "disciplined journey of graphic invention."

In the images that follow day 40 we see Michael's exhilarating growth in his ability to use the medium of digital imaging. He begins to play with collage, which opens up a whole new set of possibilities for composition. He deftly inserts the blue shoes into contemporary, vintage, and historical photographs and prints, complicating 
the semiotic ecosystems of his sources. He plays with color, type, pattern, and texture. He begins to include other shoes and eventually reconceives this new direction in terms of portraiture. Ultimately, Michael begins to focus on the attributes of the shoes, which leads to a playful and dynamic dialogue between figure and ground in plates 21-31.

The most intriguing results arrive in days 266-272 (Plates 34-37) in a series of super close-ups of details of shoes. These lush, abstract images conjure up strange landscapes or the skin of cyborgs in a sci-fi world. Michael acknowledges that this was the "most challenging" part of the project — the close-ups ushered in a perceptual shift that allowed him to look at the shoes "not as whole objects, but as the primary source of textures, colors, and patterns within micro-level images." This self-avowed breakthrough marks the transition from "teacher/scholar" to "artist" — a triumph of the rigor and discipline exerted over almost a year of blogging. In Michael's own words, "I realized most fully at this point that the pedagogical impetus with which the blog began had receded far into the background."

What began as an extension of Michael's pedagogy culminated in his transformation as an artist. I would argue that Michael's year-long experiments in The Blue Shoesled him not away from pedagogy but right to its core. Art gives us a model and a metaphor for the transformation of consciousness, the fruits of which are the development of voice and agency. The journey of grappling with our restlessness, overcoming trials, and discovering our gifts is a powerful model for rethinking education not as a force for social conditioning but as an emancipatory path for the transformation of individual minds. The journey is not easy and there are no readymade maps or guaranteed outcomes. In fact, uncertainty fuels the journey and therein lies the thrill of the quest. 


\title{
The YeAR-Long AdVentures of the Blue ShOes \& THEIR FRIENDS: An Experiment in Visual Blogging and Tutoring Athletes at the University of Nebraska-Lincoln ${ }^{1}$
}

\author{
MICHAEL R. HILL
}

The year-long adventures of the Blue Shoes began in 2013. I wore my blue Nike Hyperenforcer shoes to an Art Institute of Chicago Teacher Workshop on impressionism, fashion and modernity. ${ }^{2}$ On day one, during a studio exercise, my fellow teachers insisted on "doing something" with my Blue Shoes. Here's one result (Figure 1). And later, at home, on my own, I tried making a few photographs involving the Blue Shoes (e.g., Figure 2). Next, during a subsequent AIC session, to help us better engage with students, the Workshop leader encouraged us to start online blogs, and showed us how, step-by-step, to set one up. The Nebraska athletes I then tutored often commented on my shoes (I have a fairly large collection of athletic footwear), so I committed (without quite realizing what I was getting into) to a one-year online digital project: to post a daily visua/blog (i.e., a blog space characterized not so much by verbal commentary but primarily by graphic images) featuring athletic shoes every day for 365 days. ${ }^{3}$ I intended the blog to become a "talking point" for engaging students and helping them develop topics and individualized approaches to their writing assignments. Many athletes, I had learned, love to talk about their shoes. In face-to-face interactions, I aimed to encourage them to move from talking to writing.

\footnotetext{
${ }^{1}$ Revised and expanded from an illustrated talk presented at PechaKucha Night, St. Joseph, Michigan, 20 August 2015. The original audio-visual talk is available online via www.pechakucha.org

2 "Impressionism and Fashion," Teacher Workshop organized by Georgina Valverde and facilitated by Cheryl Pope, Art Institute of Chicago, 9-11 July 2013. Find specific information about future Art Institute of Chicago workshops at http://www.artic.edu/teacher-programs

${ }^{3}$ This type of day-by-day year-long project is by no means new. For another recent example, see Laura Kraklau, View 366, A Year-long Visual Story of the St. Joseph Lighthouses (St. Joseph, MI: View 366, LLC, 2014). A synopsis is available online: www.view366.com
} 
I took my digital camera and my Blue Shoes into the field, undertaking to make at least one new image day after day. ${ }^{4}$ At first, I placed my shoes in "found places" wherever I happened to be on any given day (e.g., Plates 1-13). I began looking at the world with an ever present question: Where can I put the Blue Shoes in this setting? I began posting the images online. I wanted my students to see that athletic shoes could be imagined in new ways and in new contexts.

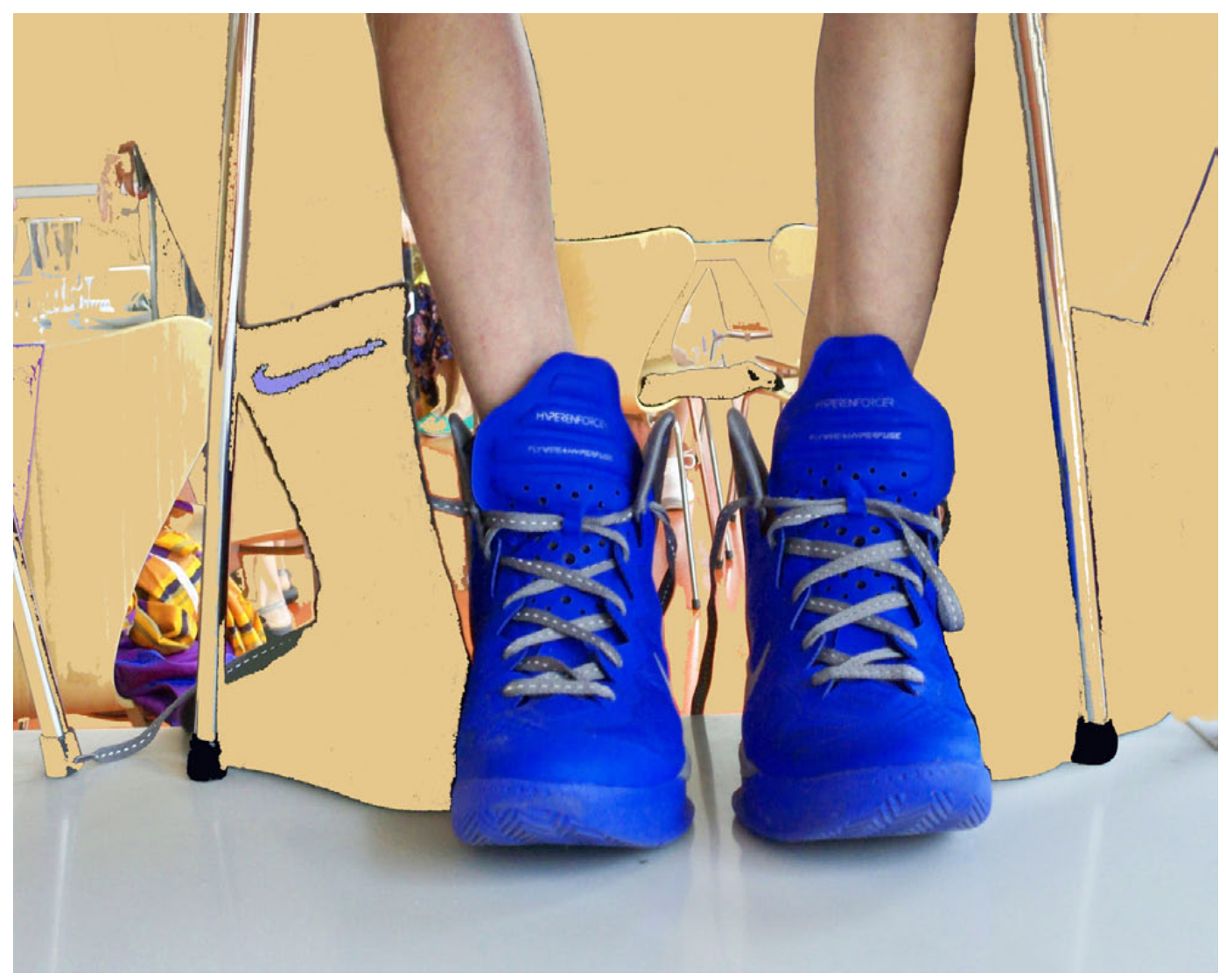

Figure 1. A/C Teacher Workshop Exercise

${ }^{4}$ Having owned (and used) cameras from age ten to the present, and having entered some of my photos in exhibitions, I was not a total neophyte. My formal training in cartography, my prior work experience in the College of Design at lowa State University, and my independent exploration of visual sociology and the sociology of the visual arts all bolstered my confidence that I could complete the project as conceived. I did not at this point, however, think of myself as an "artist." 
Seeing someone take pictures of shoes in everyday places is an unusual event. People were puzzled, even threatened, including one bank manager (but that's another story). Indeed, it took me a few weeks to become fully comfortable making pictures of the Blue Shoes in public places. Most people responded positively, however, when l explained my project and, when necessary, asked permission to take photos of their person, their property or their place of business. ${ }^{5}$ For example, when I traveled to Europe during the summer of 2013, a young waitress in Belgium (Plate 8) and a couple in The Netherlands (Plate 9) quickly and happily agreed to pose with the Blue Shoes.

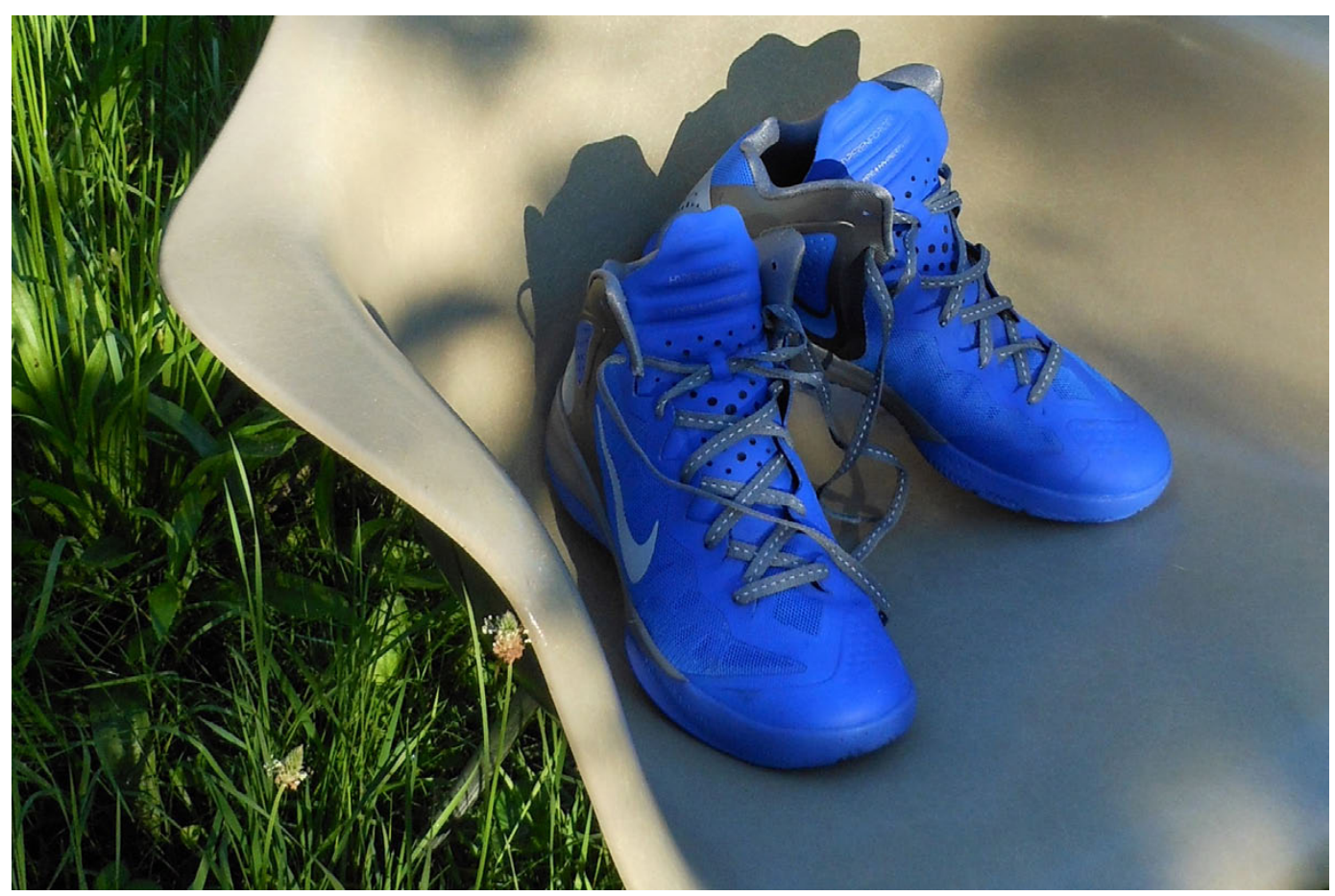

Figure 2. Personal Experiment: Eames Chair with Blue Shoes

${ }^{5}$ To facilitate interactions with strangers, I handed out "business cards" depicting the Blue Shoes, stating my name, and giving the URL for the Blue Shoes blog. 
Largely on a whim, I revisited the first Blue Shoes post. The result substantially changed the way I created many of the subsequent images, beyond simply shooting photos per se. Based on the inaugural post (Plate 1) of the Blue Shoes sitting on Michael Dunbar's powerful steel sculpture, Allegheny Drift, in the Krasl Art Center's Sculpture Garden in St.Joseph, Michigan, I sliced and diced, and added new elements and qualities to my original photo (Plate 14). I began exploring the more radical alterations available in PhotoShop CS5 Extended. In addition to the purely pedagogical aspects of my daily postings, I found I was enjoying myself and I was learning (mostly by reading manuals and by trial and error) a lot about digital image making and digital collage.

As I learned more about the possibilities presented by PhotoShop CS5 Extended, my project changed. I began inserting the Blue Shoes into existing images made by others (e.g., Plates 15-18). Thus, President Obama, himself a former university athlete, was made to dance with the First Lady at an Inaugural Ball while wearing my Blue Shoes (Plate 15). PhotoShop allowed not only insertions into extant images, but also enabled manipulations of the geometry and visual properties of the shoes themselves. The Blue Shoes could become ovals (Plate18), squares, circles even a triangle and a Great Pyramid at Giza (Plate 16).

I also started including my other, non-blue athletic shoes in the project. I have a large collection and most are Nike brand. I continued making composite images, or collages. For example, one such experiment placed my bright yellow Nikes atop blue plastic bowls and then suspended them over the sideways-tilted interior hallway in one of my old photos of the now demolished Snowflake Motel in Stevensville, Michigan (Plate 23). Themes began to emerge, including dreams (Plates 17-18) ${ }^{6}$ and an exploration of repeated patterns (Plates 19-20).

It was an easy progression to present my shoes as integral components in still life arrangements (Plates 21-22). It eventually dawned on me that I was, in a sense, making portraits of shoes. I began including shoes in or with portraits of people. For example, to an earlier triptych of Chicago's Van Buren Street Metra Station that I

\footnotetext{
${ }^{6} \mathrm{No}$, should anyone be curious, I never personally had any dreams about shoes; these were the imagined dreams of the shoes themselves.
} 
made in 2012 (and which featured my superimposed photos of a young, female scholar ${ }^{7}$ ), I now gave parallel standing to the Blue Shoes themselves (Plate 28).

Plates 32-33 present images from an "abstraction" series in which I tried looking at shoes not as shoes per se, but as elements of form, shape, and color. Month-long themes became the organizing principle of my blog: first, dreams and patterns, followed by still life, environments, portraiture, abstraction, and so forth.

The most challenging monthly series featured close-ups of parts of athletic shoes. It was a major shift in direction for me to look at shoes not as whole objects, but as the primary source of textures, colors, and patterns within micro-level images (Plates 34-37).

Another monthly series I called "Feet On the Ground" (Plates 38-40), during which I returned to my original practice of making photos wherever I happened to be each day, but this time in a more systematic and narrowly focused manner. I looked down, every day, to look closely at what I was standing on as I walked from place to place. I was amused that a parking lot surface in Santa Ana, California, happily featured former Chicago Bull's athlete Michael Jordan's jersey number: "23" (Plate 39). Before reaching the end of my self-imposed "year," I was given a wonderful opportunity to share what I was doing with other teachers.

At the 2014 annual Art Institute Curriculum Fair (Figure 3), I presented a juried lesson plan called "My Shoes in Words and a Picture" (Appendix I, below, pages 6975). Designed as a mechanism to overcome neophyte writer's block, I demonstrated that Nebraska's student athletes could photograph their favorite shoes and then write about them without hesitation. Presenting their work here, however, raises a complication. NCAA rules prohibit endorsements of athletic equipment by student athletes. Thus, I cannot reproduce any work created by Nebraska athletes especially work pertaining to their athletic shoes - without placing them in jeopardy. As an alternative, please consider Figure 4 (p. 7) and Figure 5 (p. 76). These photos

\footnotetext{
${ }^{7}$ Shahrazad Shareef, who is now completing a $\mathrm{PhD}$ in literature and continental philosophy at Duke University, generously allowed me to take her portrait during a Teacher Workshop focused on the photography of Dawoud Bey in July, 2012, at the Art Institute of Chicago.
} 
by a non-athlete are fully equivalent and prompted an insightful and comparable essay on the meaning of her shoes from the perspective of a creative, very bright foreign student grappling with English as a second language (Appendix II, below, page 77).

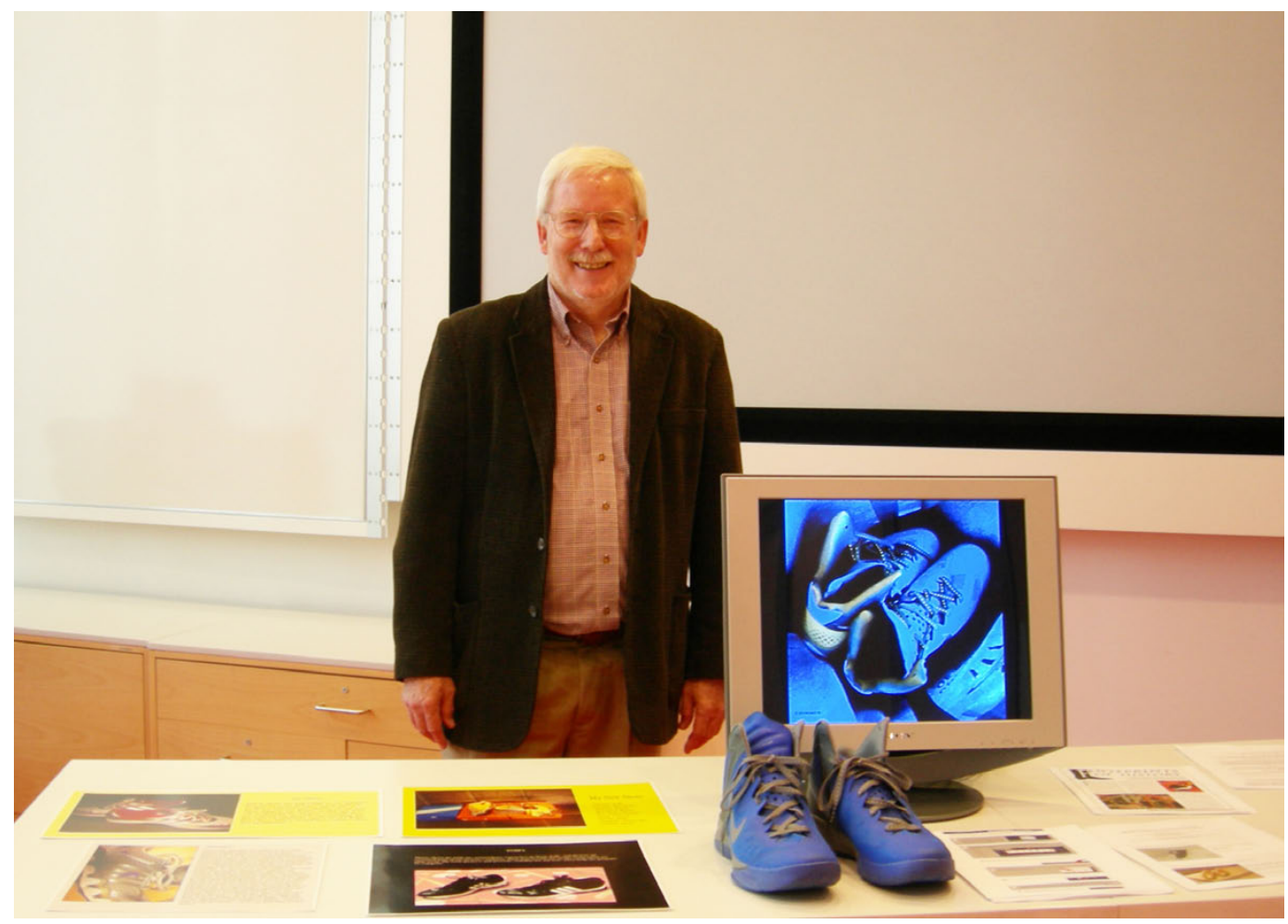

Figure 3. The Author at the A/C Curriculum Fair, 2014

The 2014 Art Institute Curriculum Fair also allowed me to introduce several teachers to PhotoShop procedures in a "live" setting, and a few fellow educators created and posted their own Blue Shoes, including one that placed Mouse Ears on Pomodoro's Sphere within a Sphere at the United Nations Building. 
During the last weeks of the Blue Shoes annualis, I took a member sketch class at the Art Institute focused on Surrealism. ${ }^{8}$ My subsequent blog posts reflected several applications of surrealist principles including: repetition, floating images, negative spaces, and random elements from nature (Plates 41-46, 49-52). I realized most fully at this point that the pedagogical impetus with which the blog began had receded far into the background. The Blue Shoes had gradually taken on a life of their own, as did some images (Plates 47-48, for example) that didn't "fit" into the final series of surrealist experiments. I hadn't bargained for it, but I was getting more out of the project than had my students, and as the project moved into the summer recess, I became completely captivated by the intrinsic rewards of creating graphic images as such.

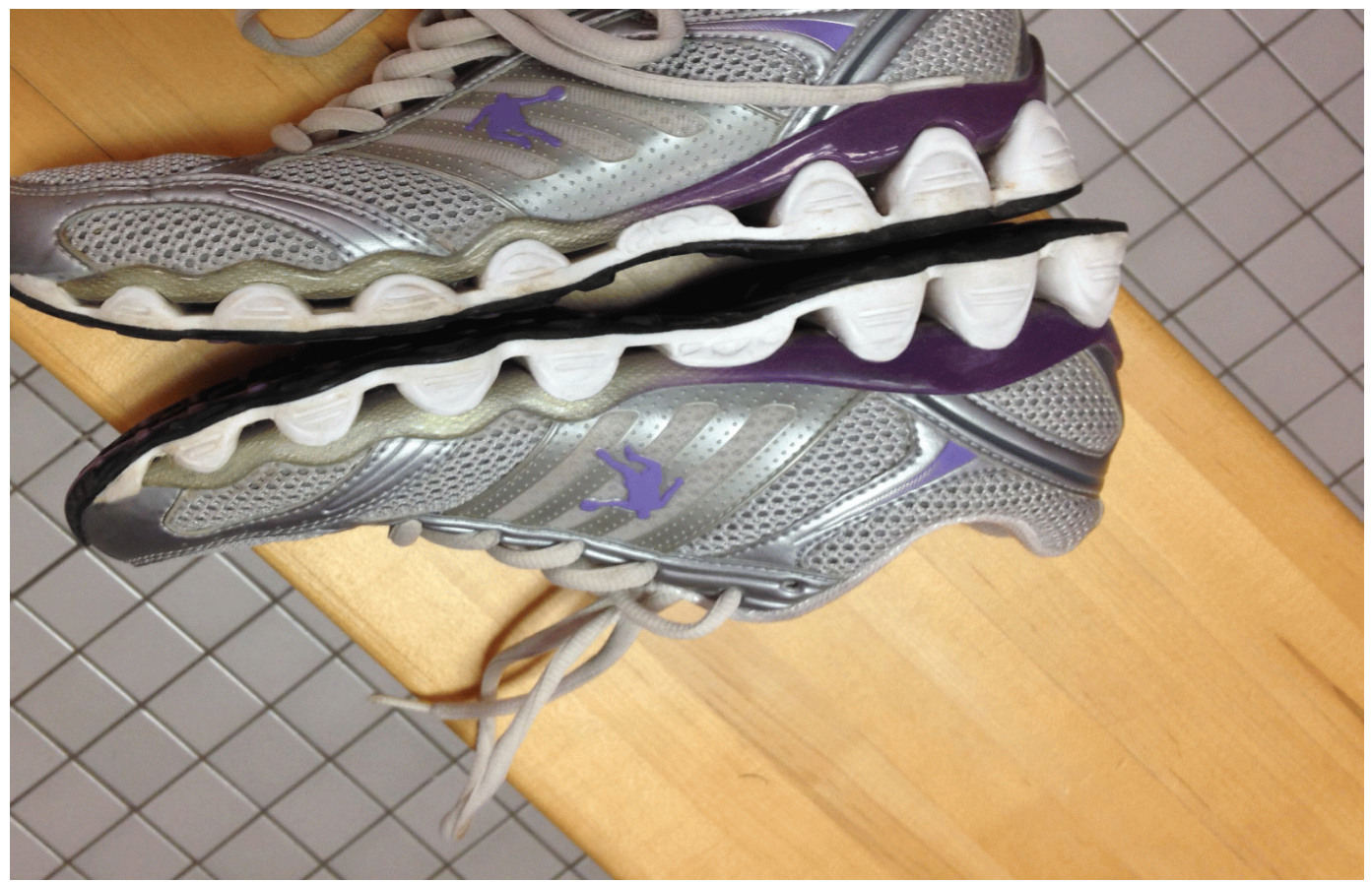

Figure 4. Example Student Photograph

${ }^{8}$ Taught by Mark Krisco, Art Institute of Chicago, June \& July, 2014. 
Throughout the year, students gave me feedback — usually face to face about my blog, and a few realized that athletic shoes could be about more than athletics or shoes per se. Early on, with regard to Plates 2, 3, \& 4, one perceptive student observed, in part:

... When you place the shoes underneath a modern dress, on a wheelchair symbol, or even a bike it makes the viewer think of your reasoning for the placement of the shoes but also makes me think of the world when it comes to fashion and what I or people of my generation think to be acceptable. When I saw the mannequin in the pink dress with the stylish necklace and then, of course, the blue shoes, I could totally relate. Although as an athlete I could relate more to the shoes, even with them being a man's shoes. But, for any student-athlete in my case, being female, I rarely get the opportunity to express my gender through my clothing. It made me reflect on my daily wardrobe and activities I am involved in on a day to day basis. Even today as it's more acceptable to wear athletic clothes - I still do not wear the "brand-name" Lulu Lemon yoga pants or tanks. I do on some occasions, but it is a rare. But while pondering this I also have realized that in my community of student-athletes I am the "norm" because we all wear the same clothing, girls included....

In the long run, however, I became at least as much interested in my images as images, than specifically as teaching tools. Suffice it to say that by the end of The Year-Long Adventures of the Blue Shoes and Their Friends, I had gained new insights into discipline, playfulness, teaching, and making digital images. Here's the URL for the blog. ${ }^{9}$ Please visit online. Click the "archive" tab and the full 365 days of posts will be revealed for your perusal and comment (at least for as long as tumblr.com keeps the site running). In the meantime, the following plates provide a chronological sample from the images I created on a day-to-day basis. I began the year comfortably self-

${ }^{9}$ The URL for the Blue Shoes project is: www.absence-in-art.tumblr.com Please note that the project proper began with the post made on August 1, 2013 - all else is prelude. 
identifying as "scholar/teacher," but at year's end I looked in the mirror and said, OK, still "scholar/teacher," but also "artist." 10

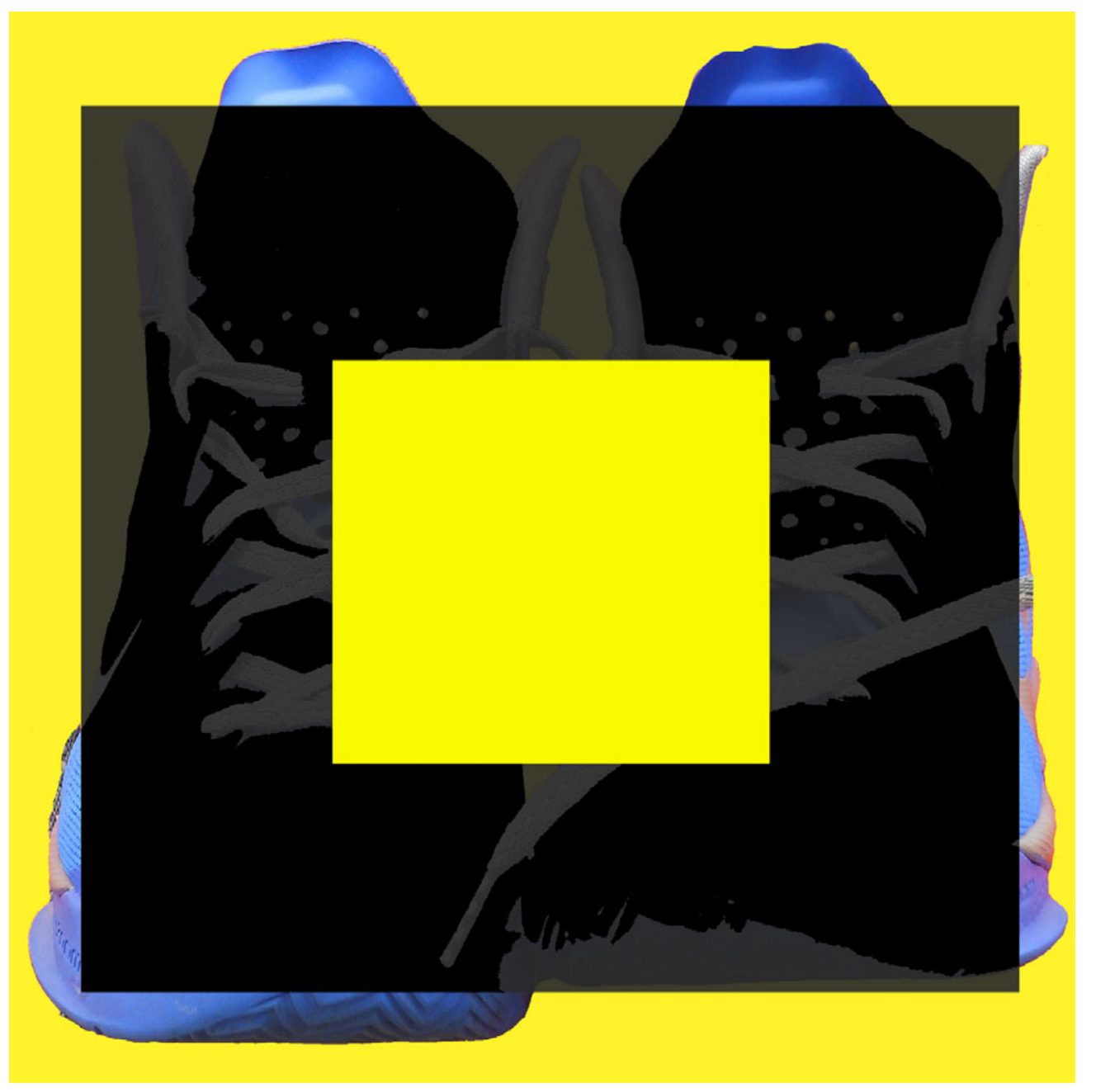

${ }^{10}$ This outcome, technically speaking, was a liminal journey resulting in an augmented professional self (MJ Deegan \& MR Hill (1991), "Doctoral Dissertations as Liminal Journeys of the Self: Betwixt and Between in Graduate Sociology Programs," Teaching Sociology 19 (3): 322-32). My new work as a Volunteer Docent in the K-12 Understanding Art Program at the Krasl Art Center in St. Joseph, Michigan, nicely incorporates both artistry and teaching. 


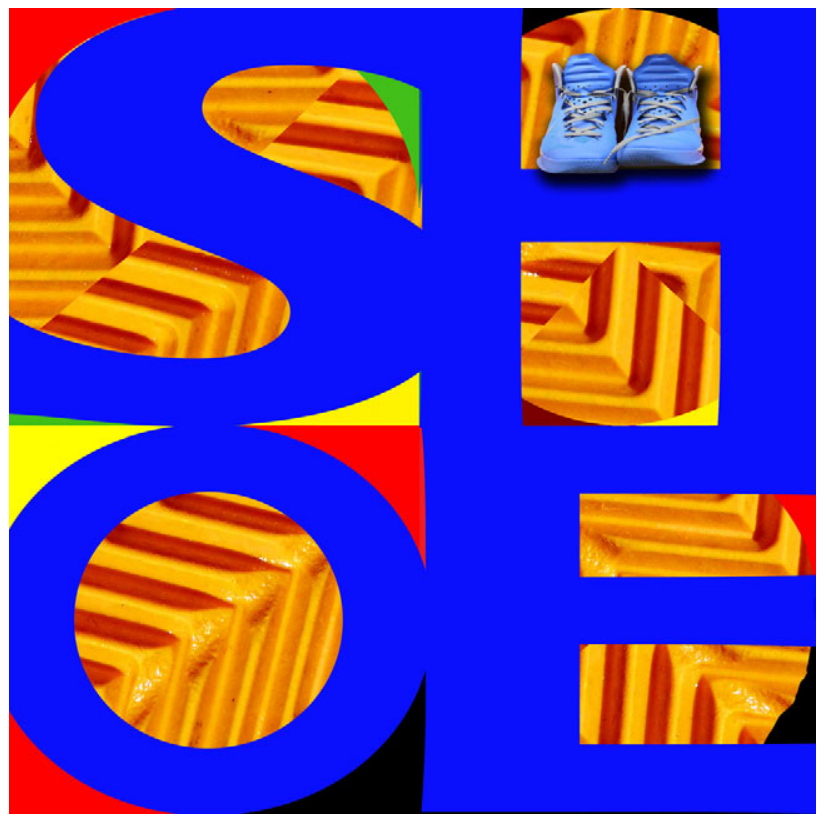


The Plates:

52 Selected Posts from the Visual Blog 


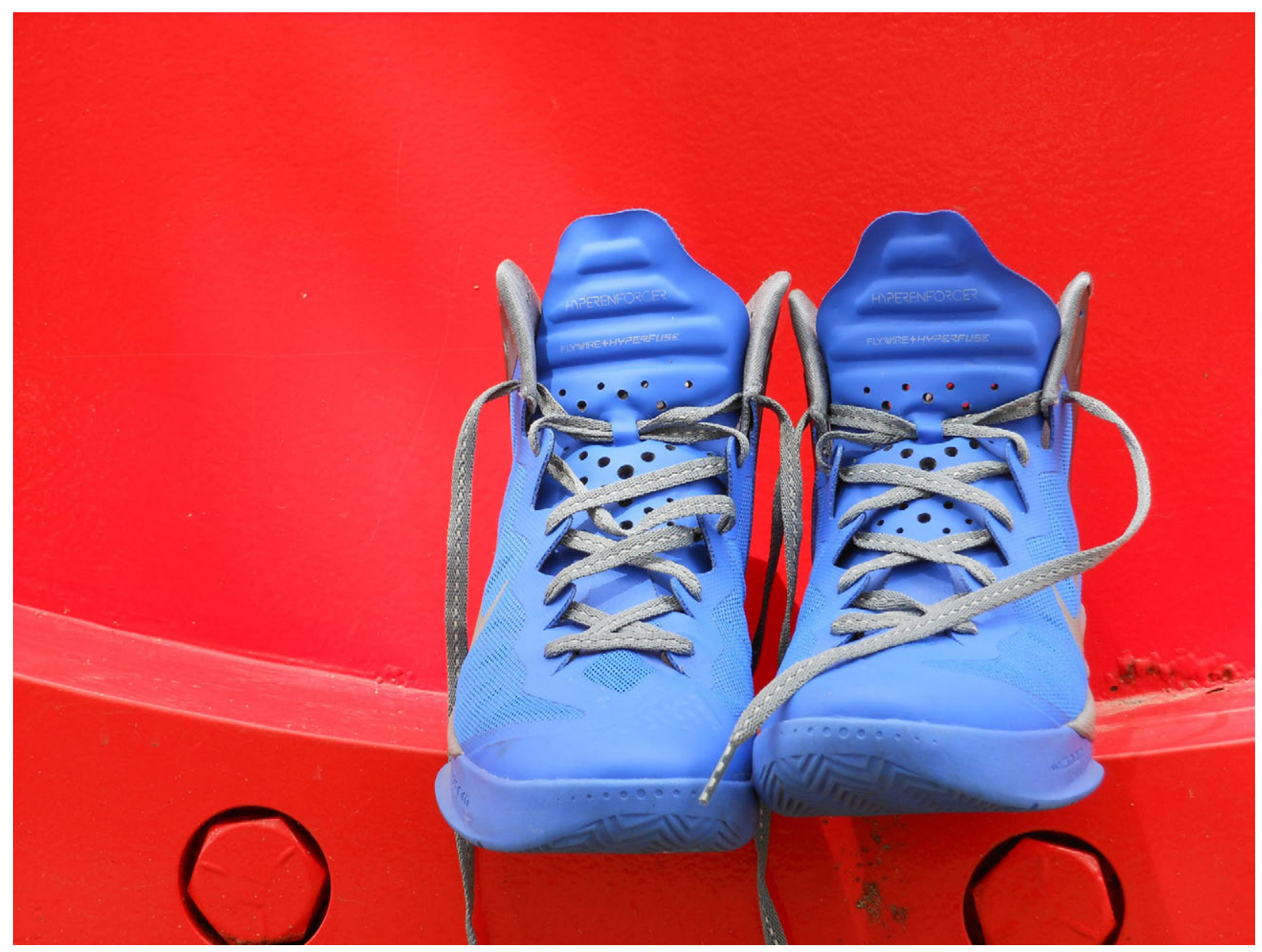

Plate 1. Day $1-$ Krasl Art Center, St. Joseph, Michigan 


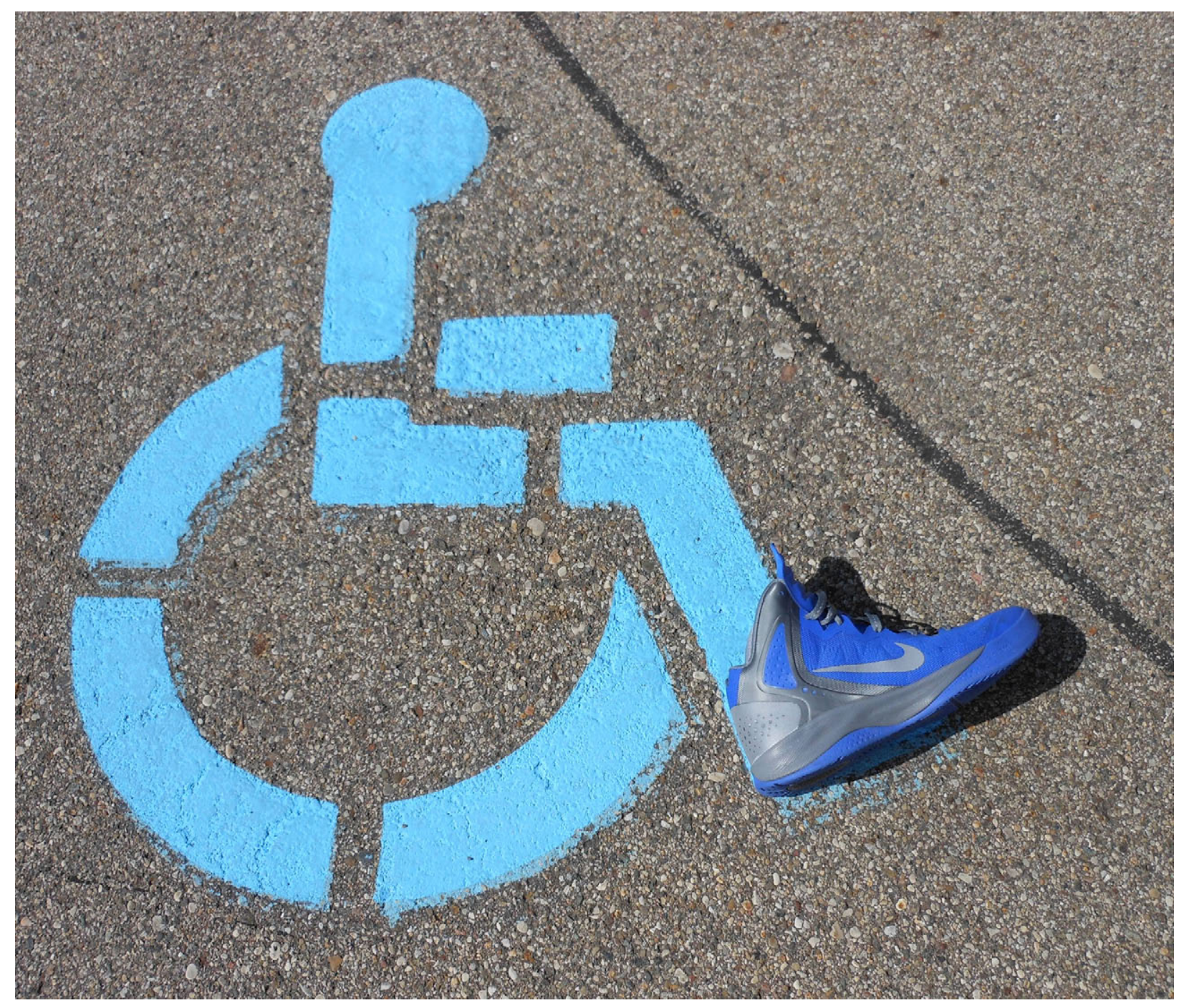

Plate 2. Day 3 - Parking Lot, Holland, Michigan

Opposite page

Plate 3. Day 7 - Unicycle, Mizpah Park, Michigan 


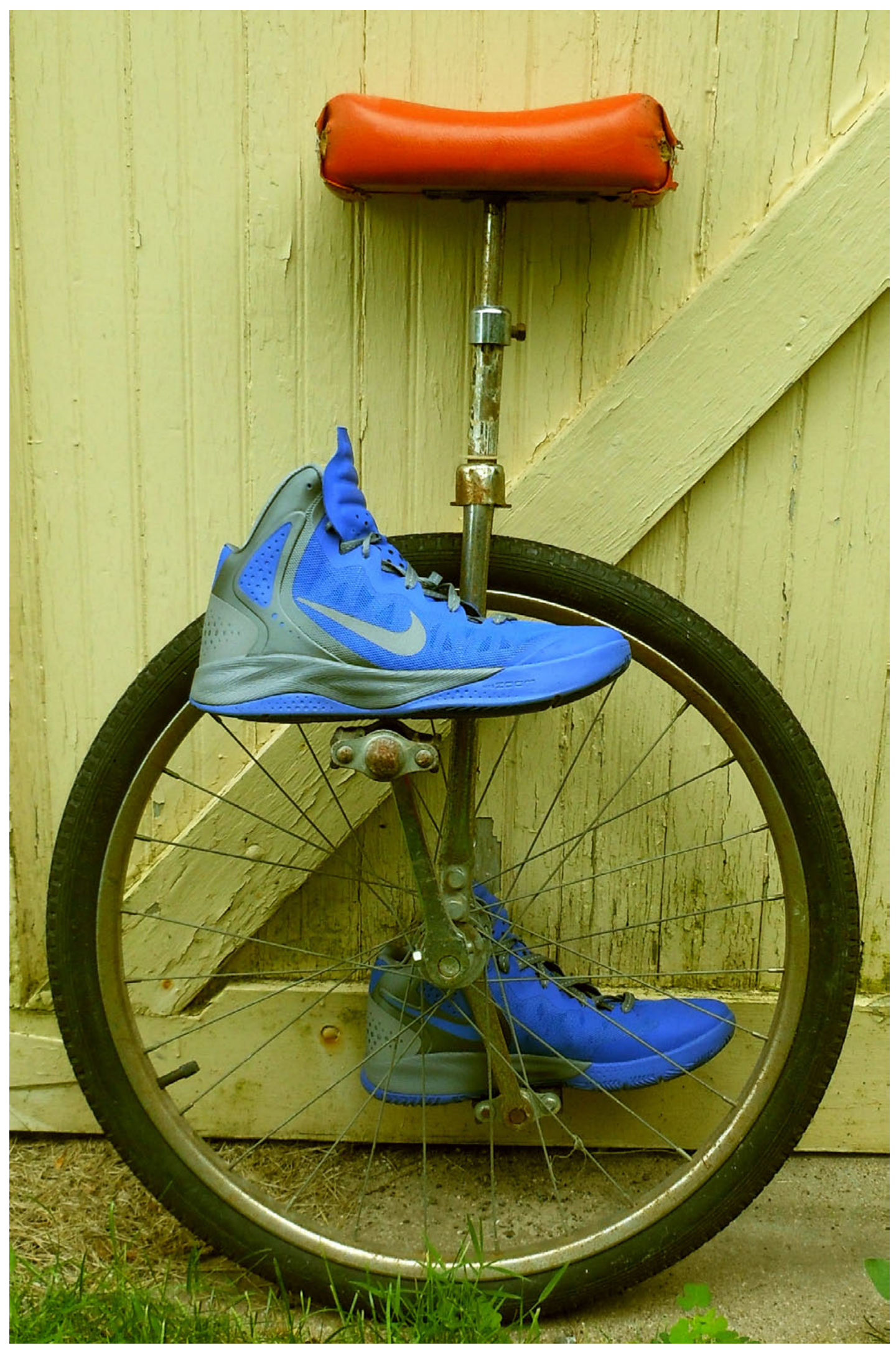




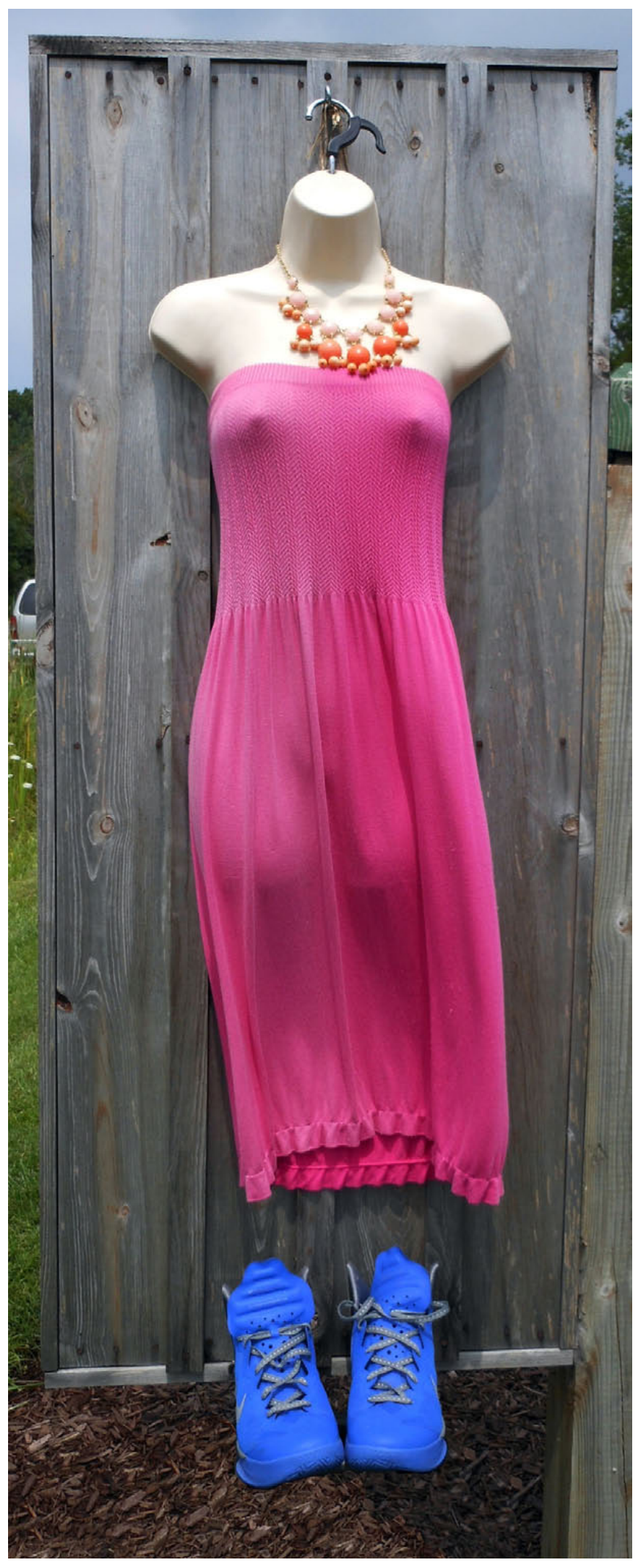




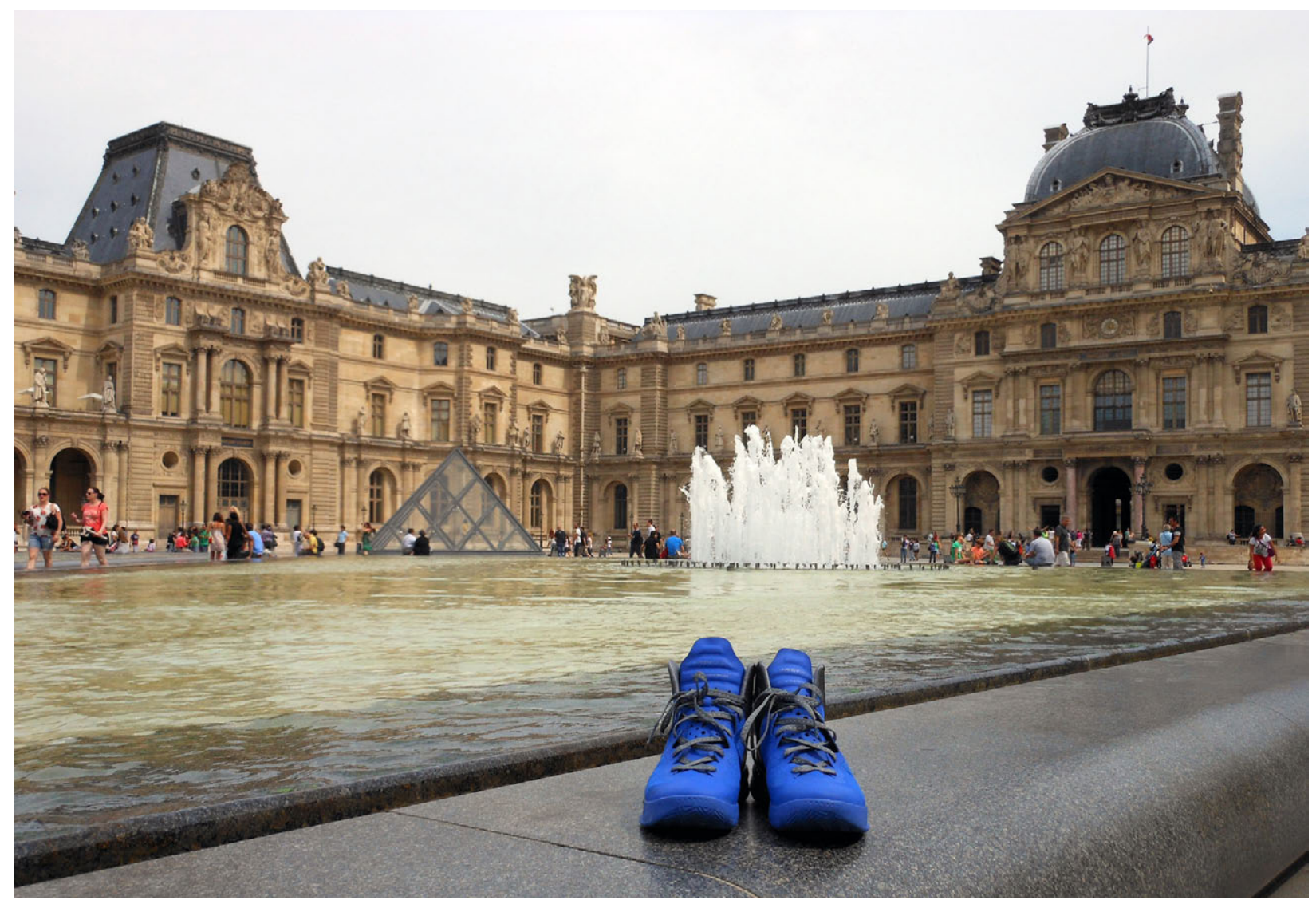

Plate 5, Day 22 - The Louvre, Paris, France

Opposite page

Plate 4. Day 12 - Outdoor Shop Display, Saugatuck, Michigan 


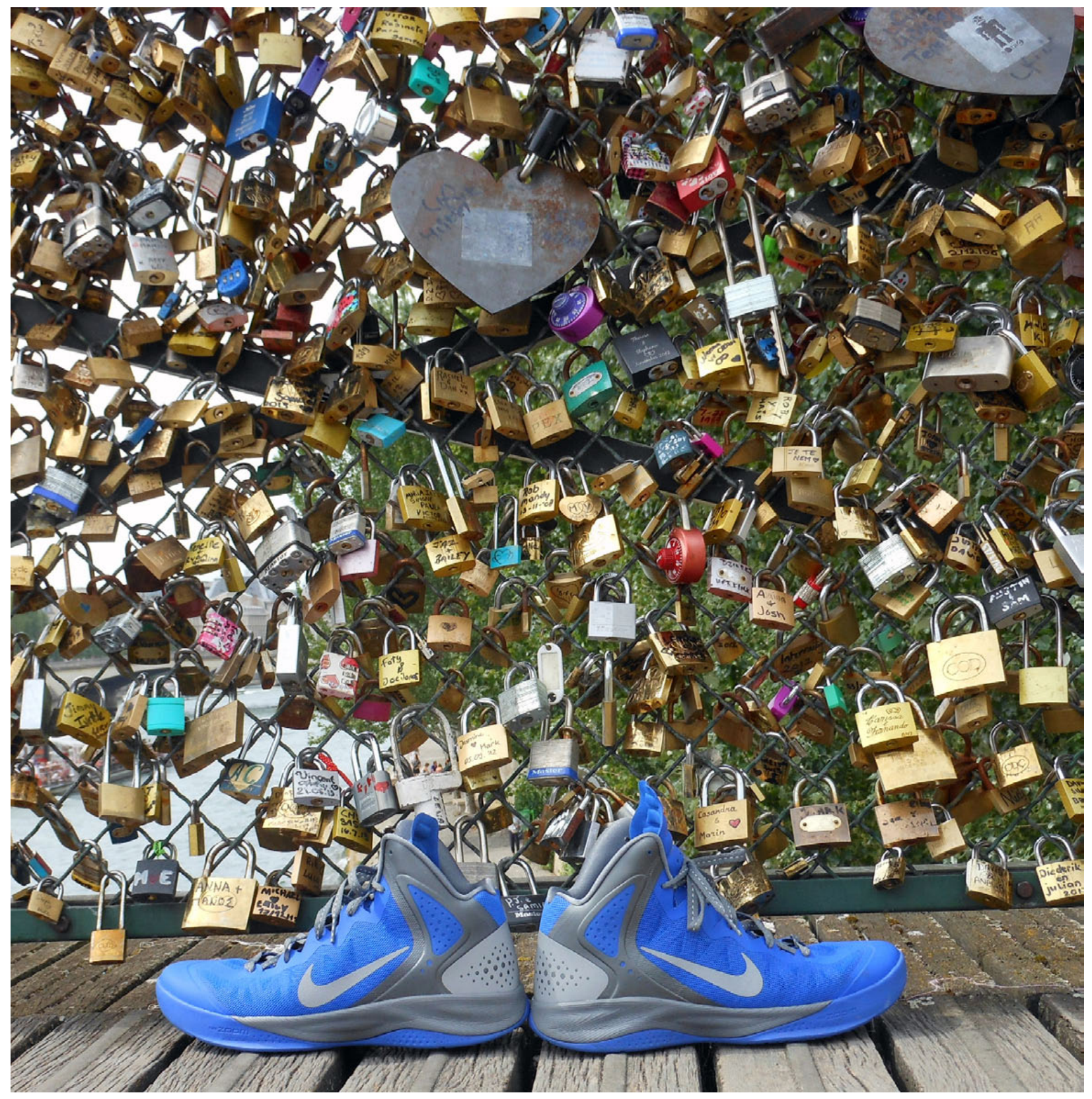

Plate 6. Day 22 - Pont des Arts, Paris, France 


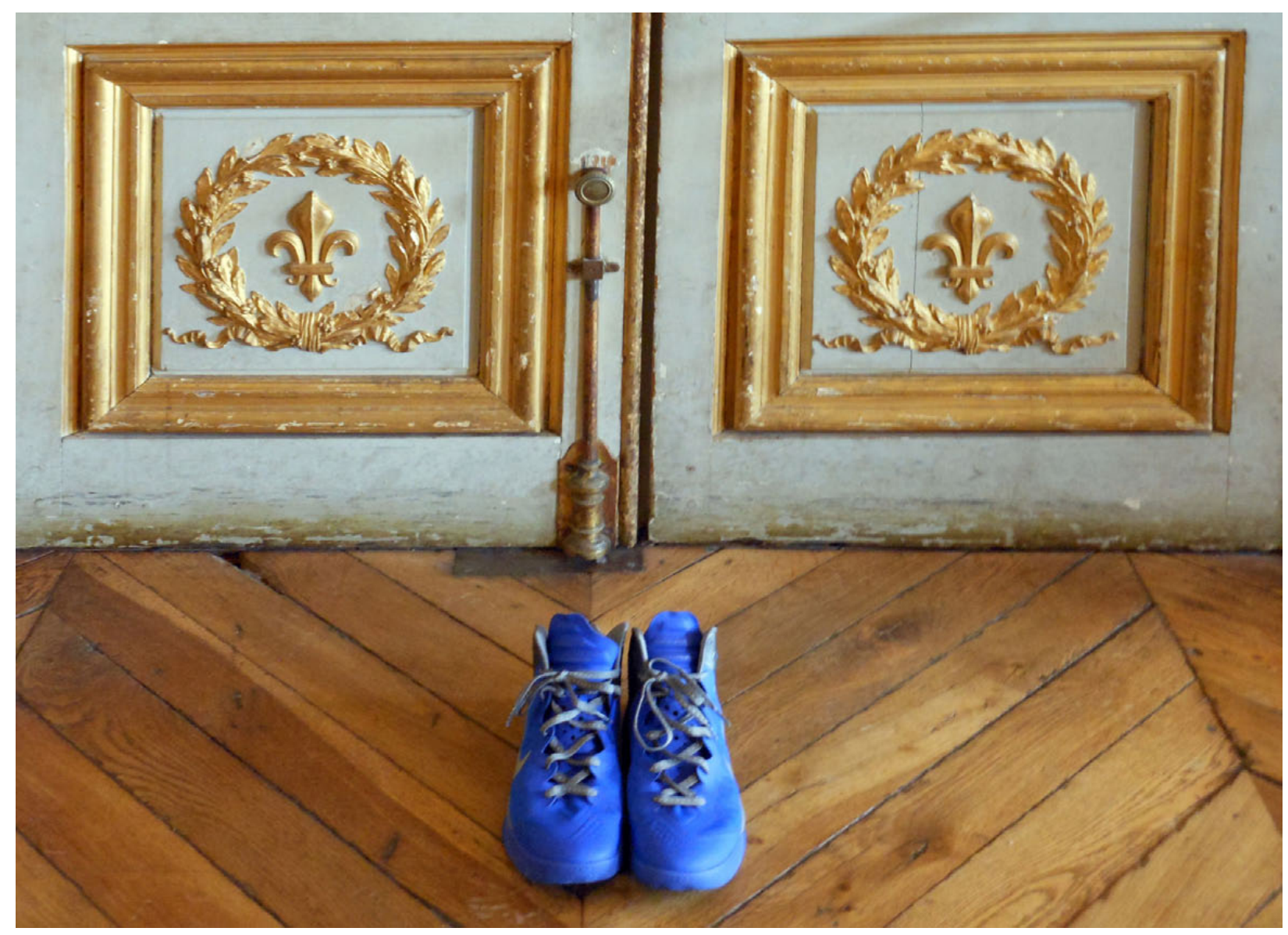

Plate 7. Day 22 - Palace of Versailles, Versailles, France 


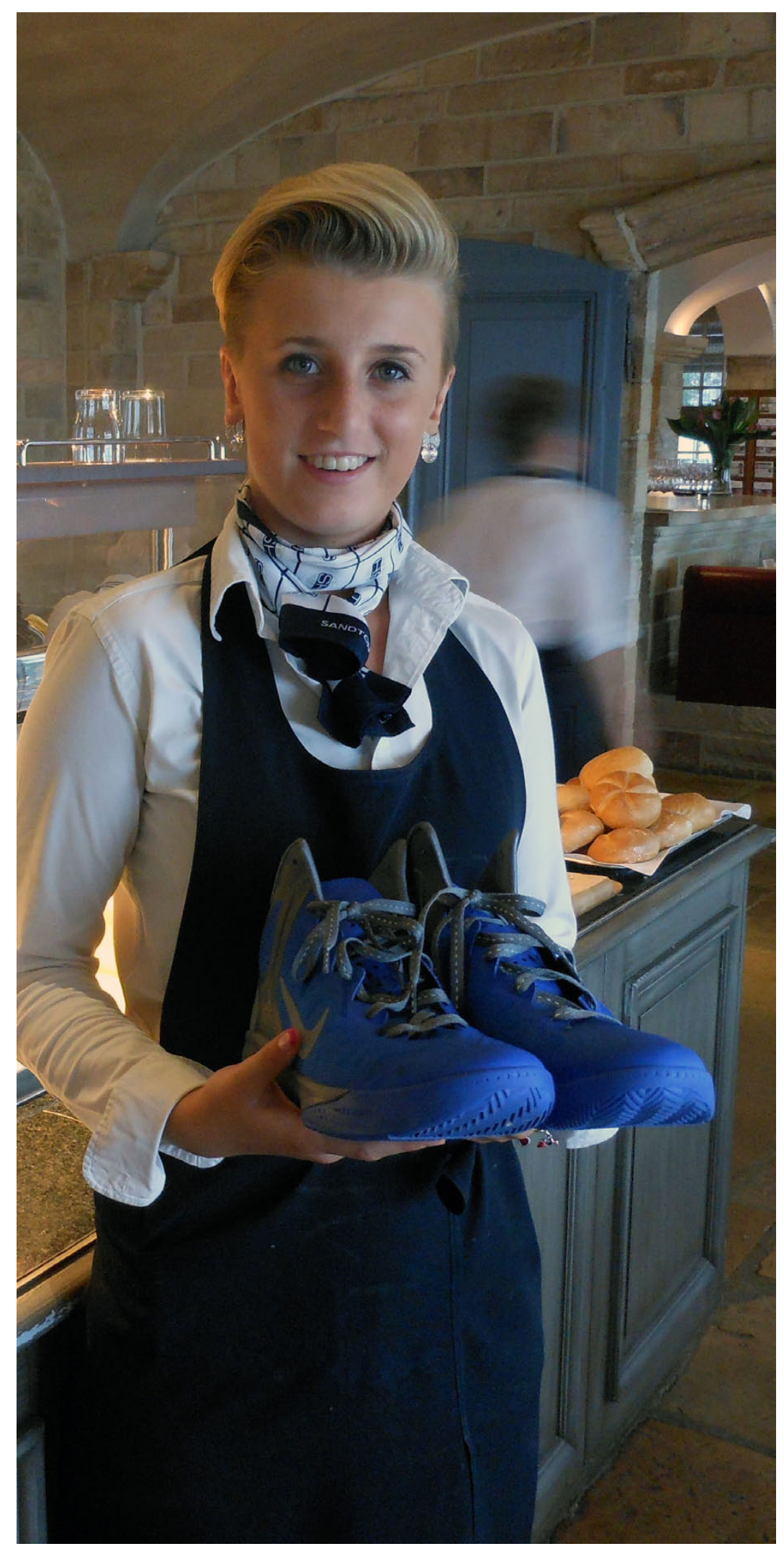




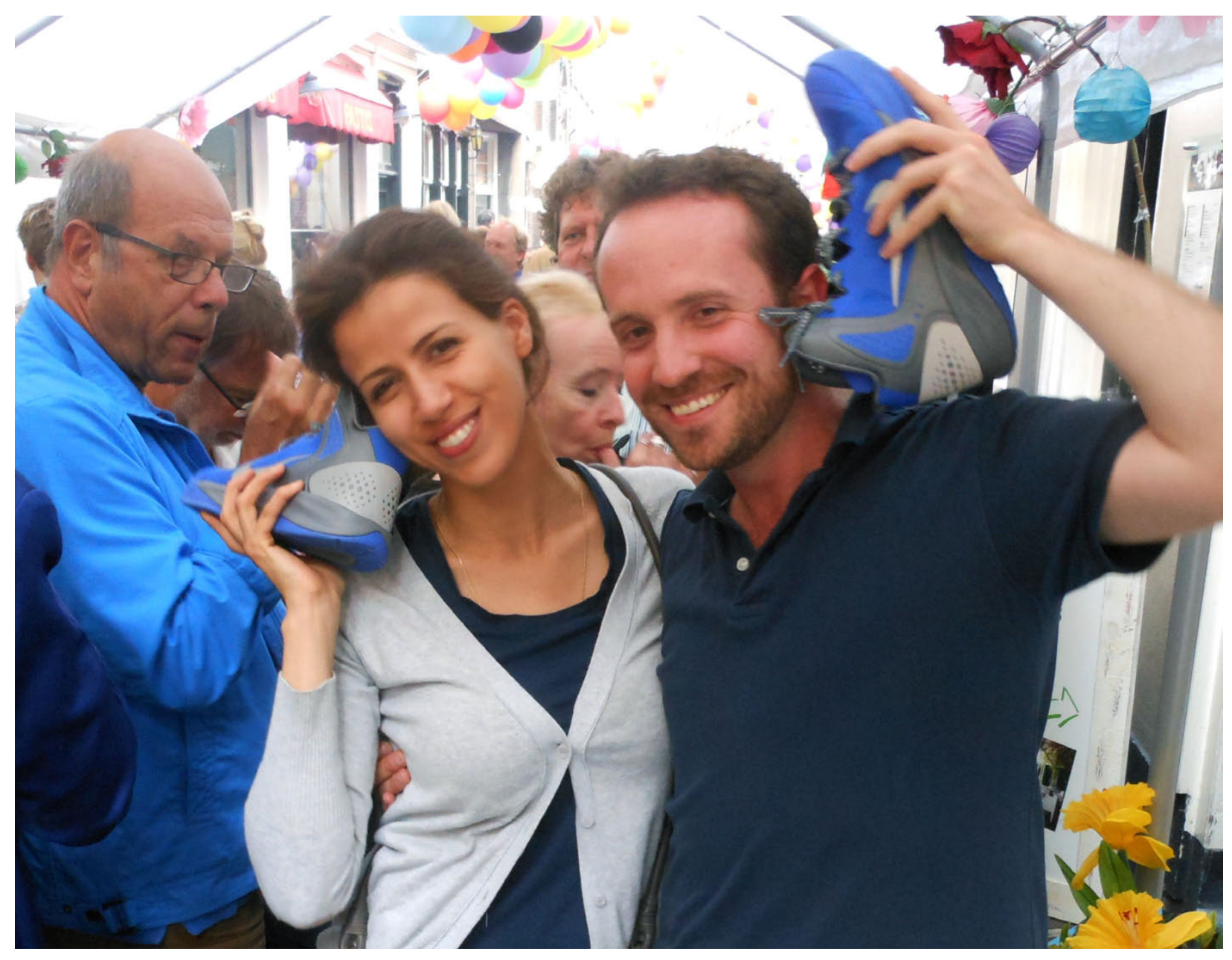

Plate 9. Day 25 - Street Party, The Hague, The Netherlands

Opposite page

Plate 8. Day 24 - Hotel Broel, Kortrijk, Belgium 


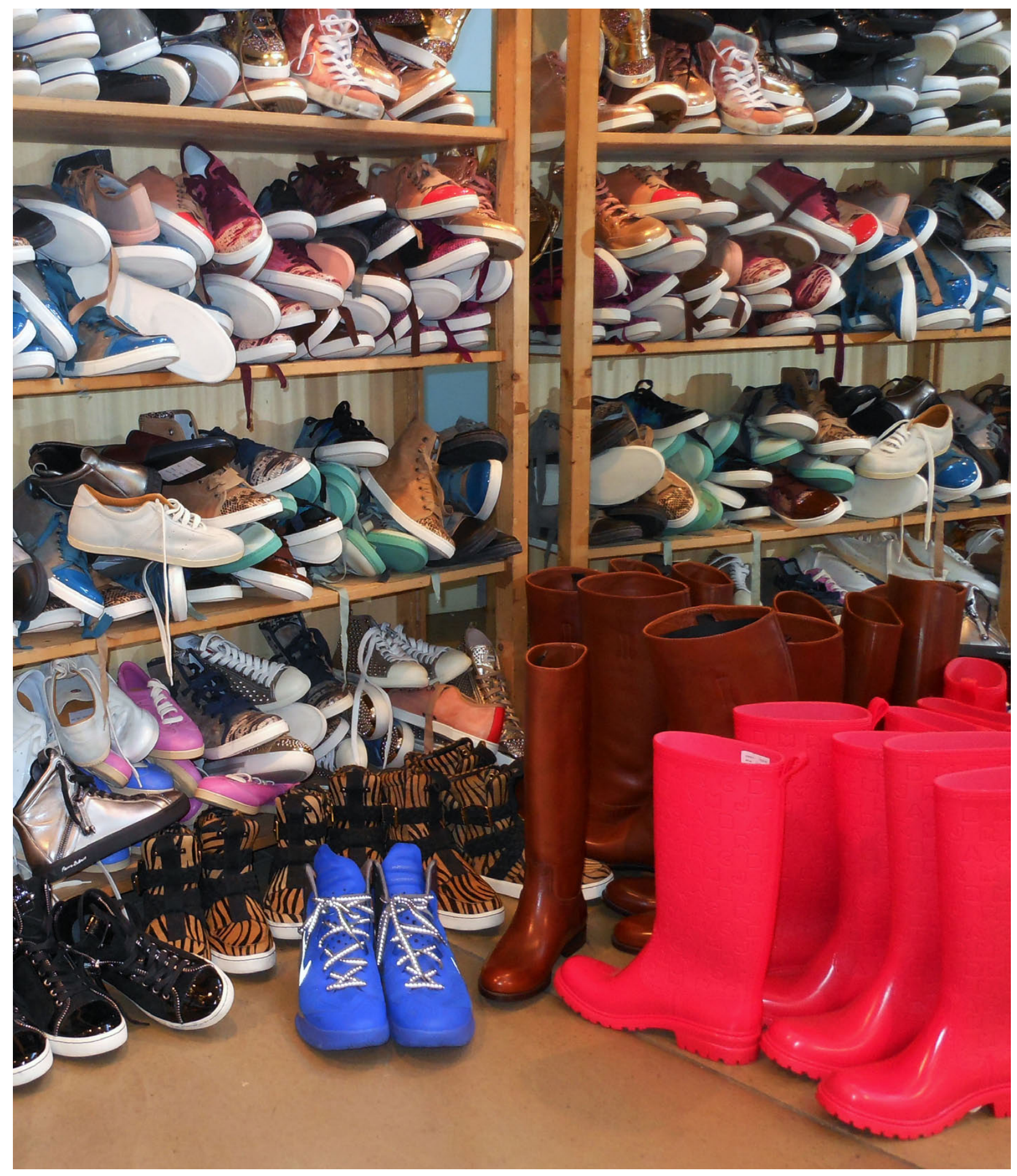

Plate 10. Day 26 — Shoe Store, The Hague, The Netherlands 


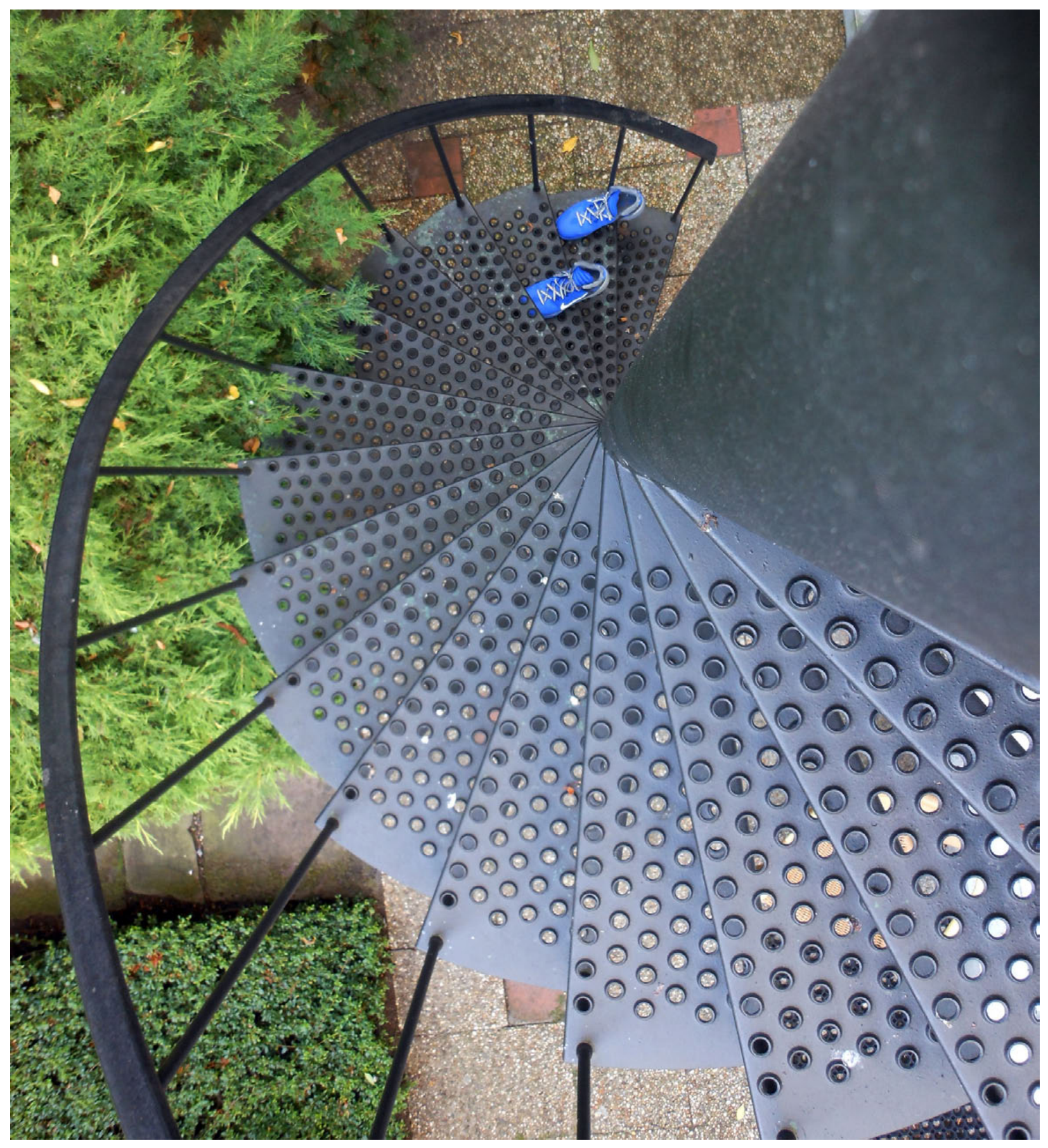

Plate 11. Day 27 - Parkhotel, The Hague, The Netherlands 


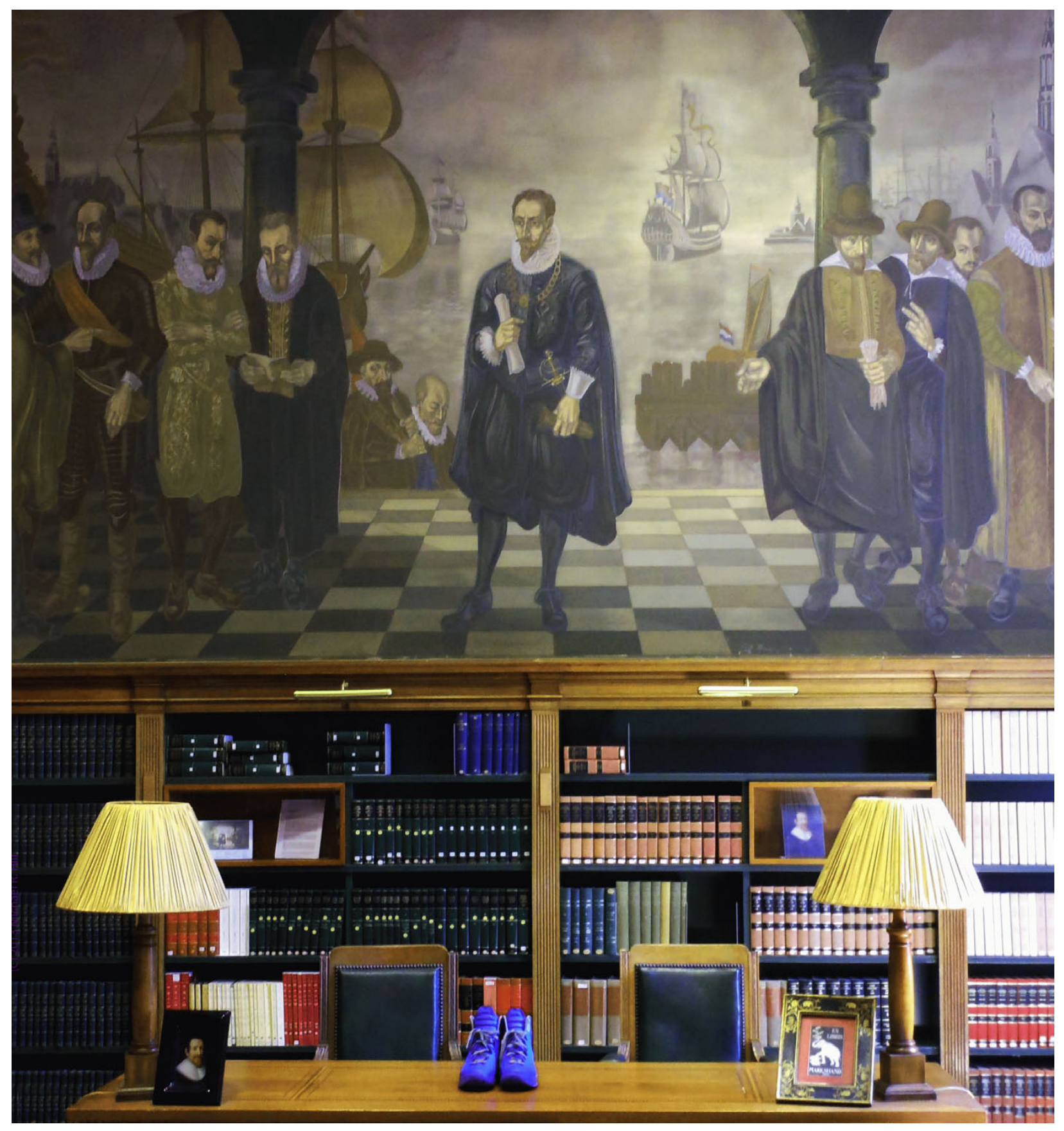

Plate 12. Day 27 - Library, Peace Palace, The Hague, The Netherlands 


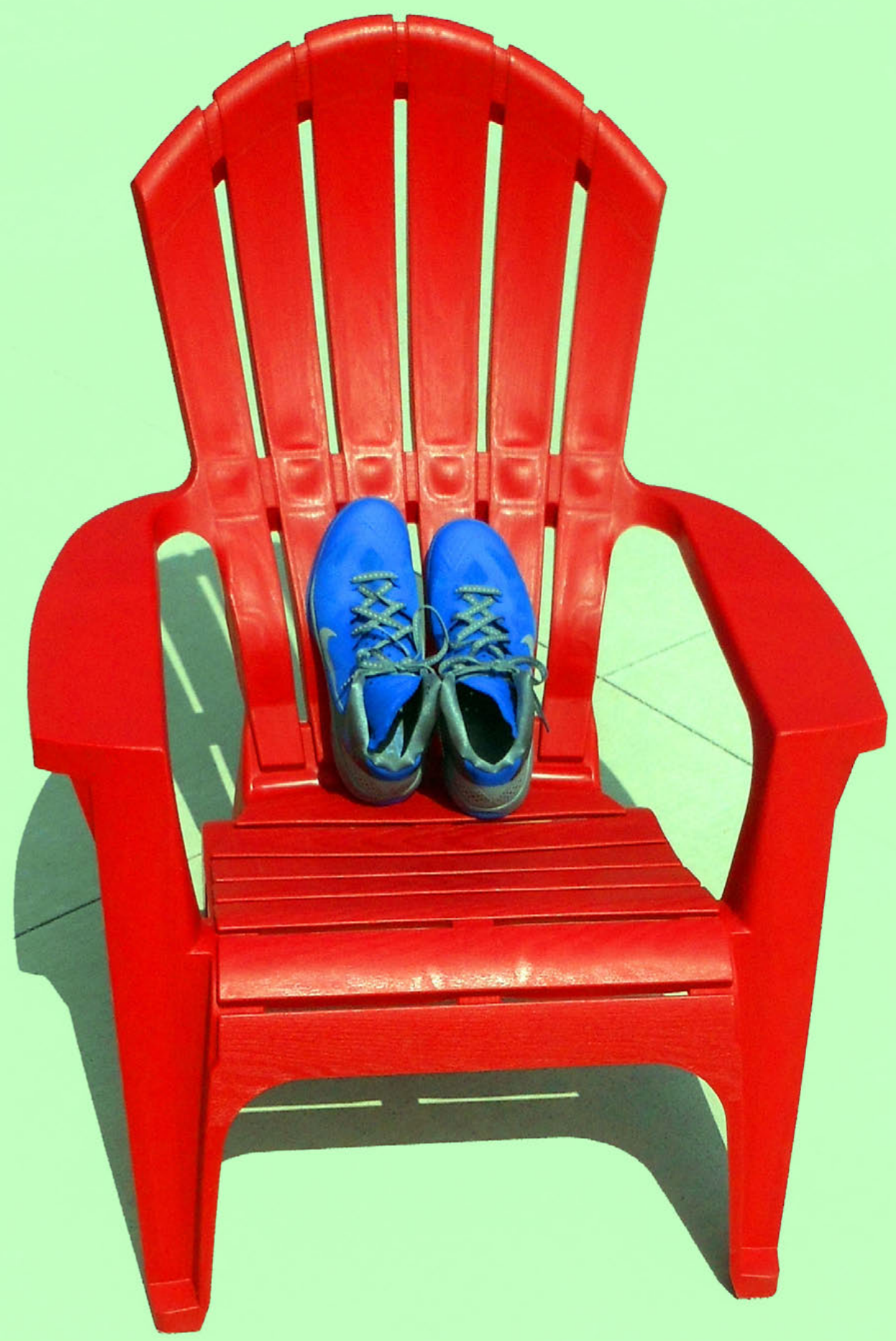




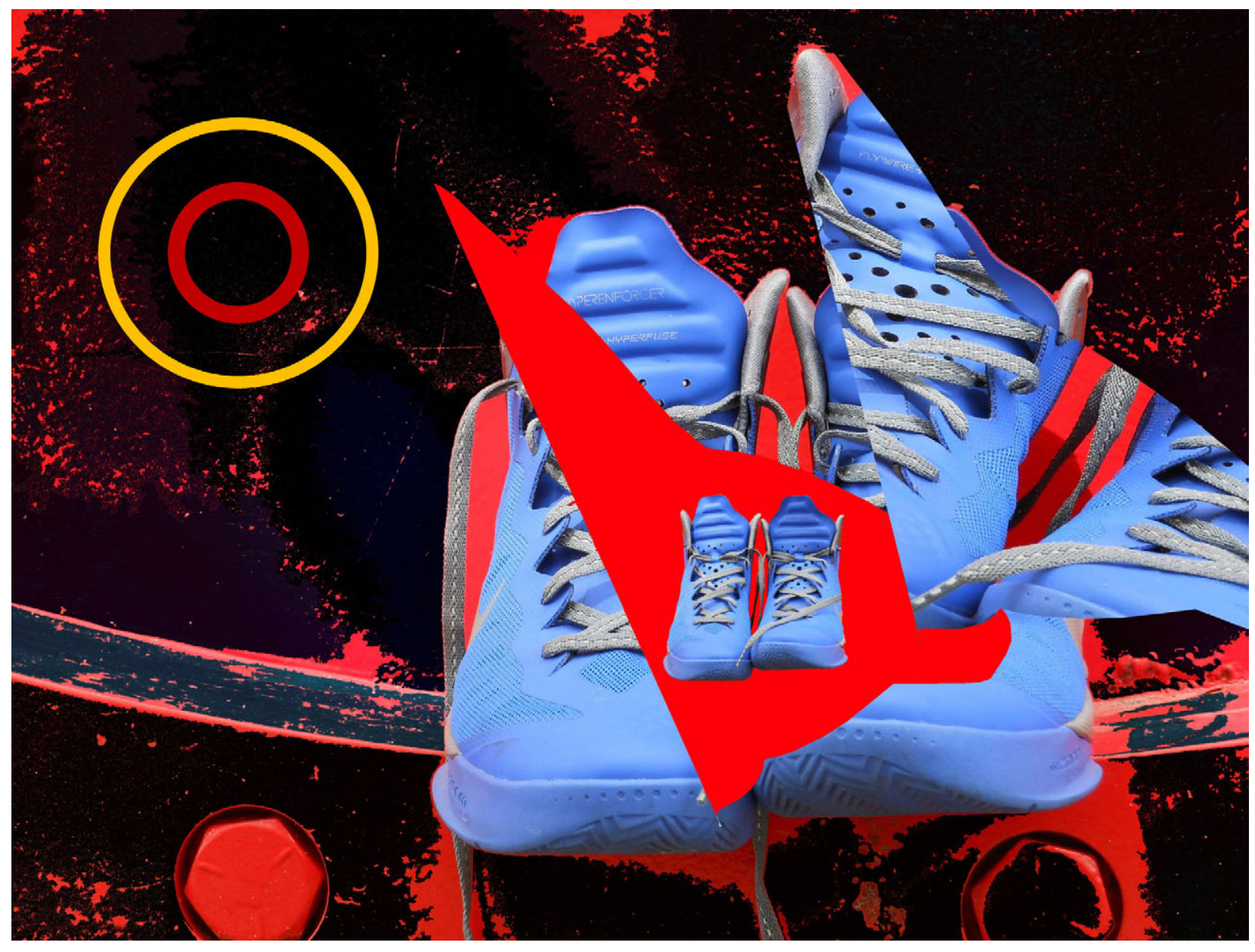

Plate 14. Day 40 - Circles and Slices (digital collage) 


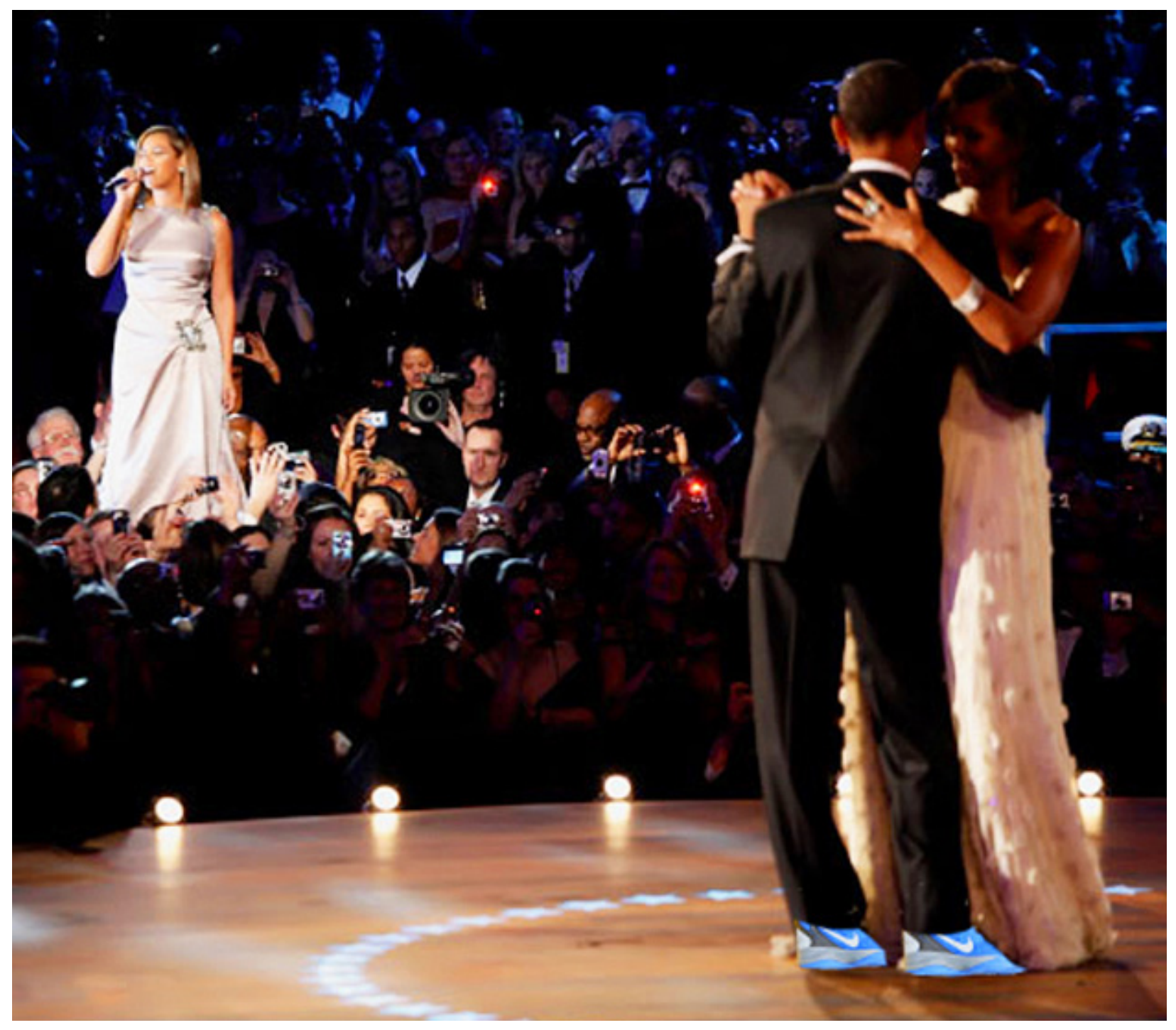

Plate 15. Day 48 — Inaugural Ball (digital collage parody, original photo by D. Winter) 


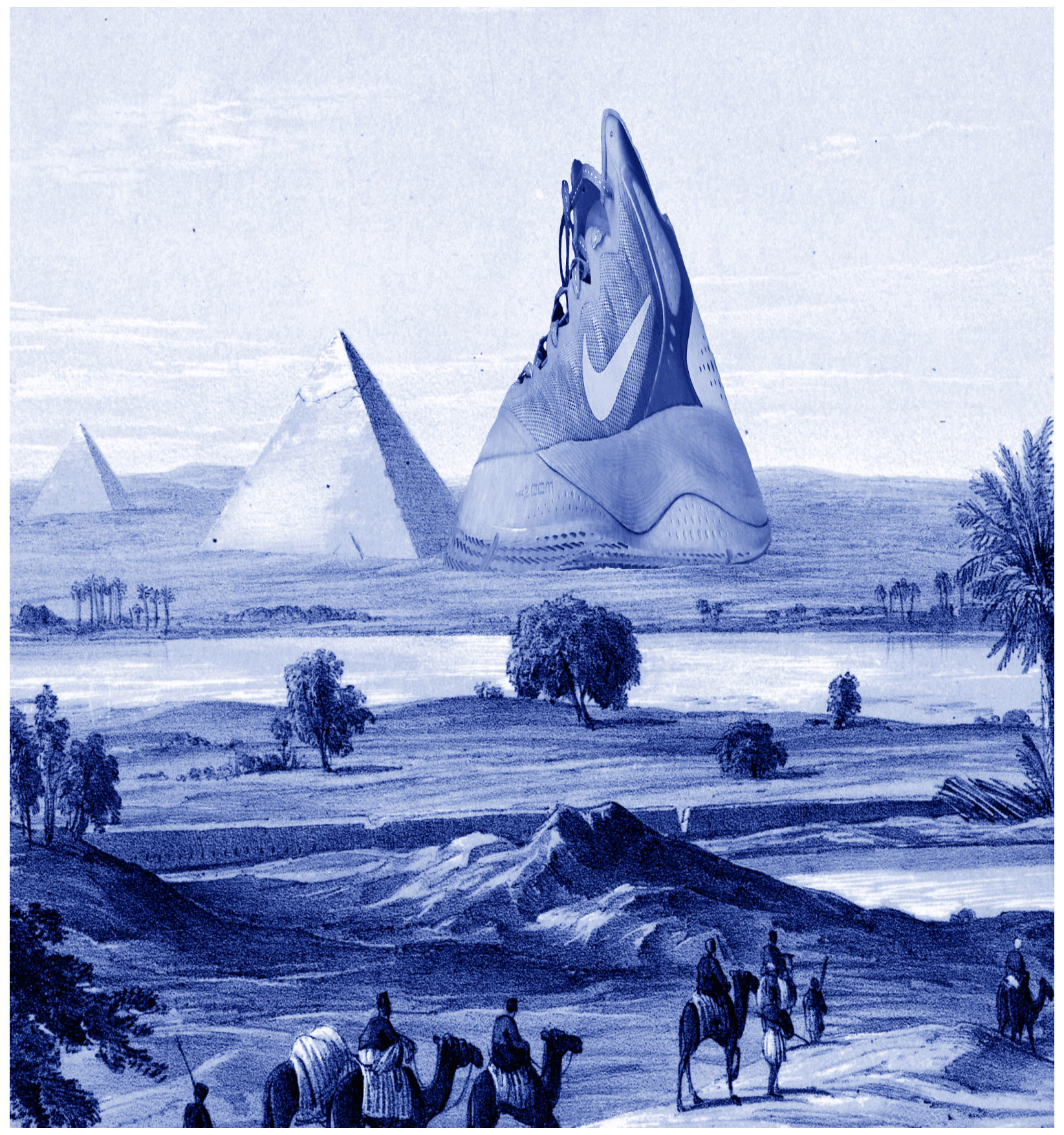

Plate 16. Day 60 — Blue Pyramids at Giza (digital collage parody, Owen Jones drawing) 


\section{Suddenly, the Blue Shoe remembered being prodded by phrenologists at the University of Nebraska.}

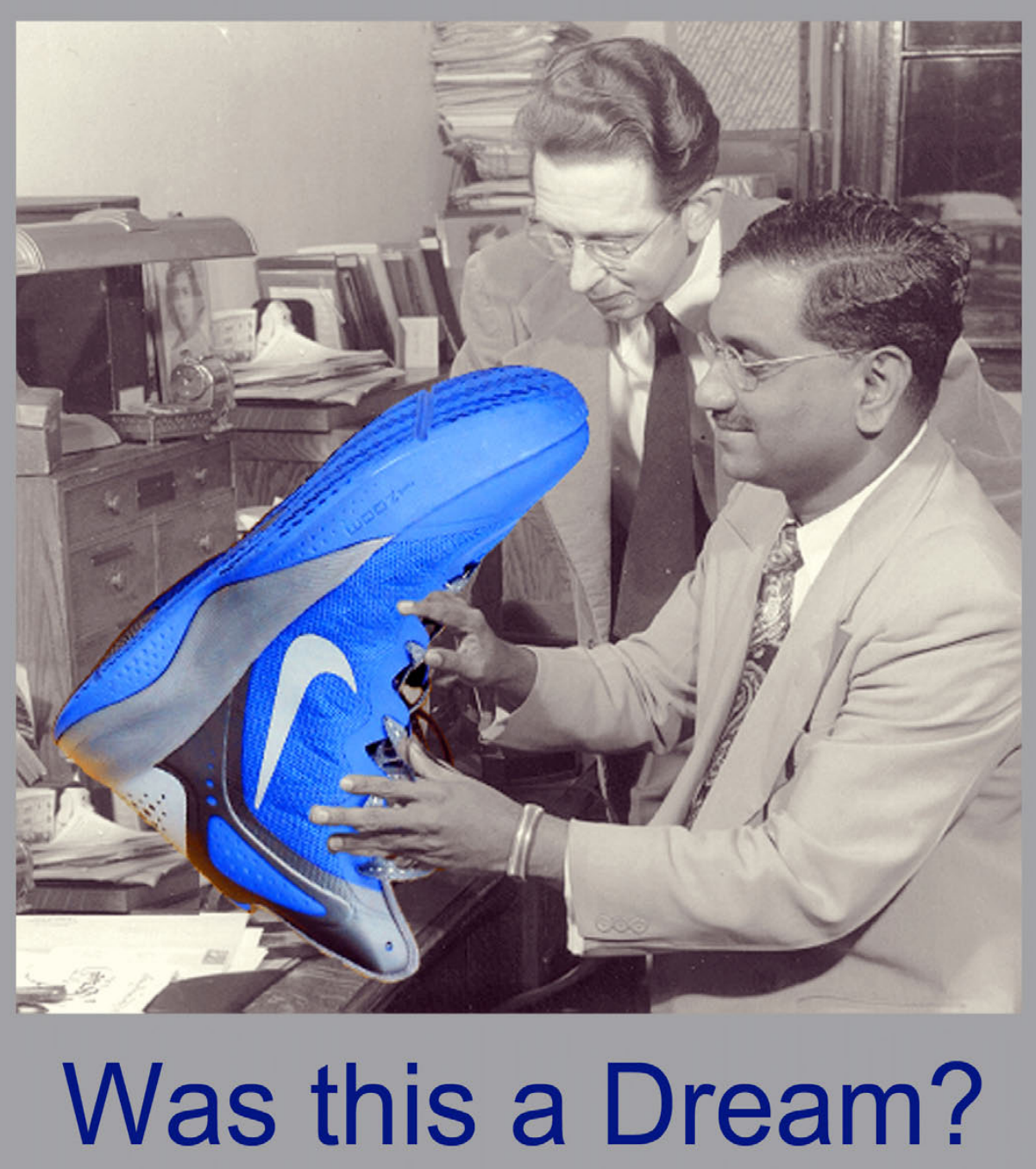




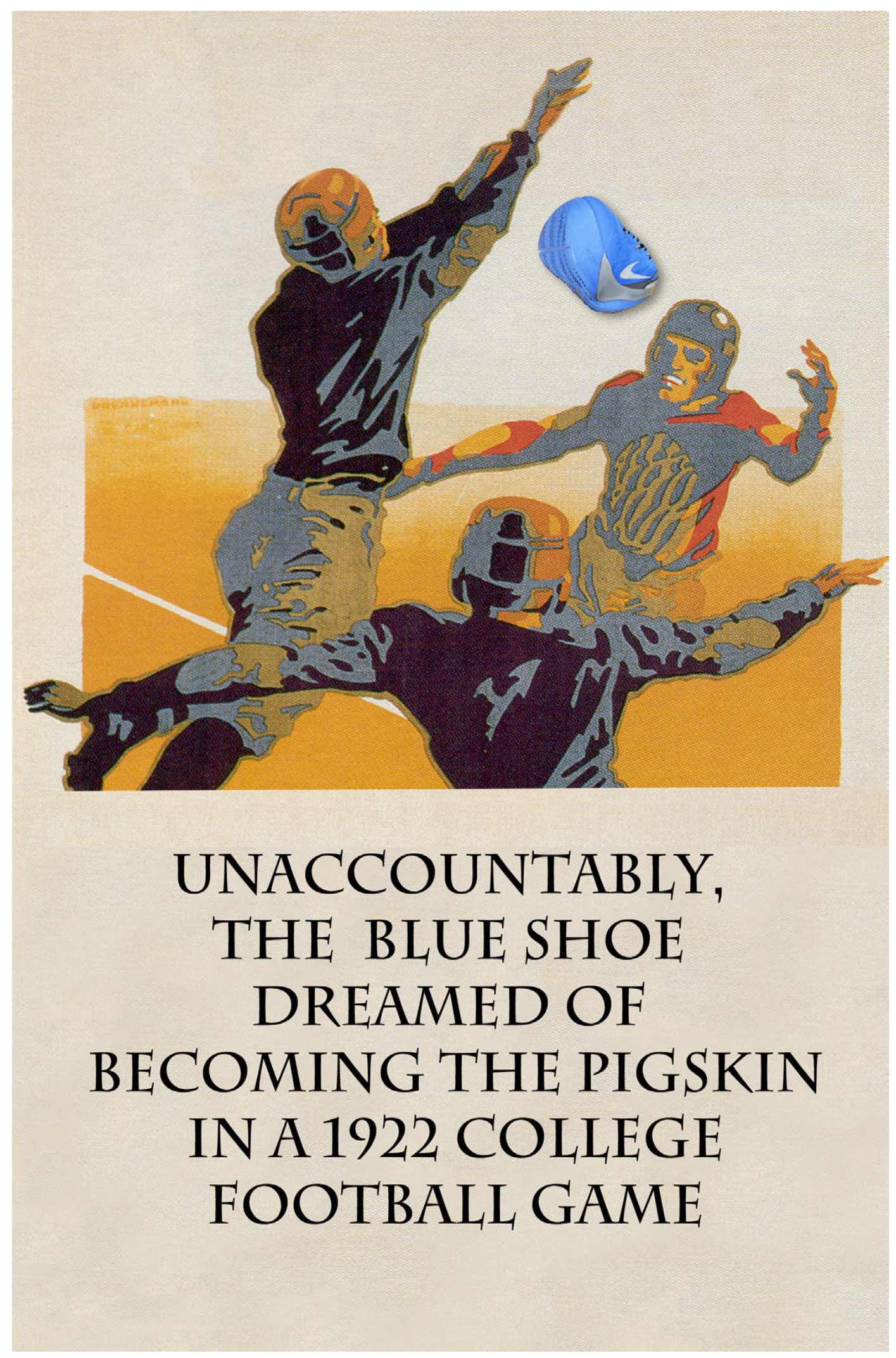




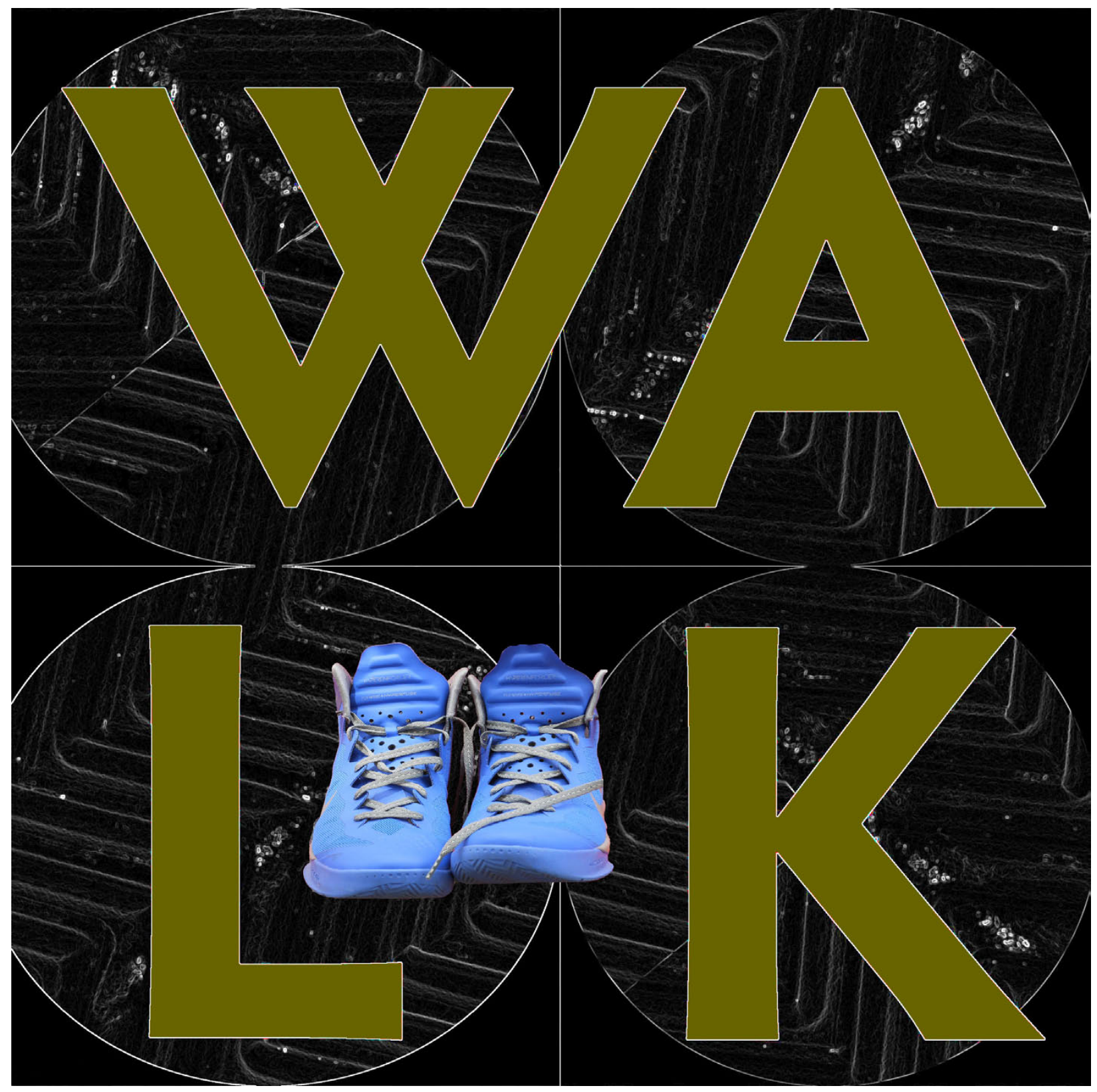

Plate 19. Day 108 - WALK, Pattern Study, No. 16 (digital collage)

\section{Opposite page}

Plate 18. Day 65 - Pigskin Dreams (digital collage parody, vintage South Shore Railroad poster) 


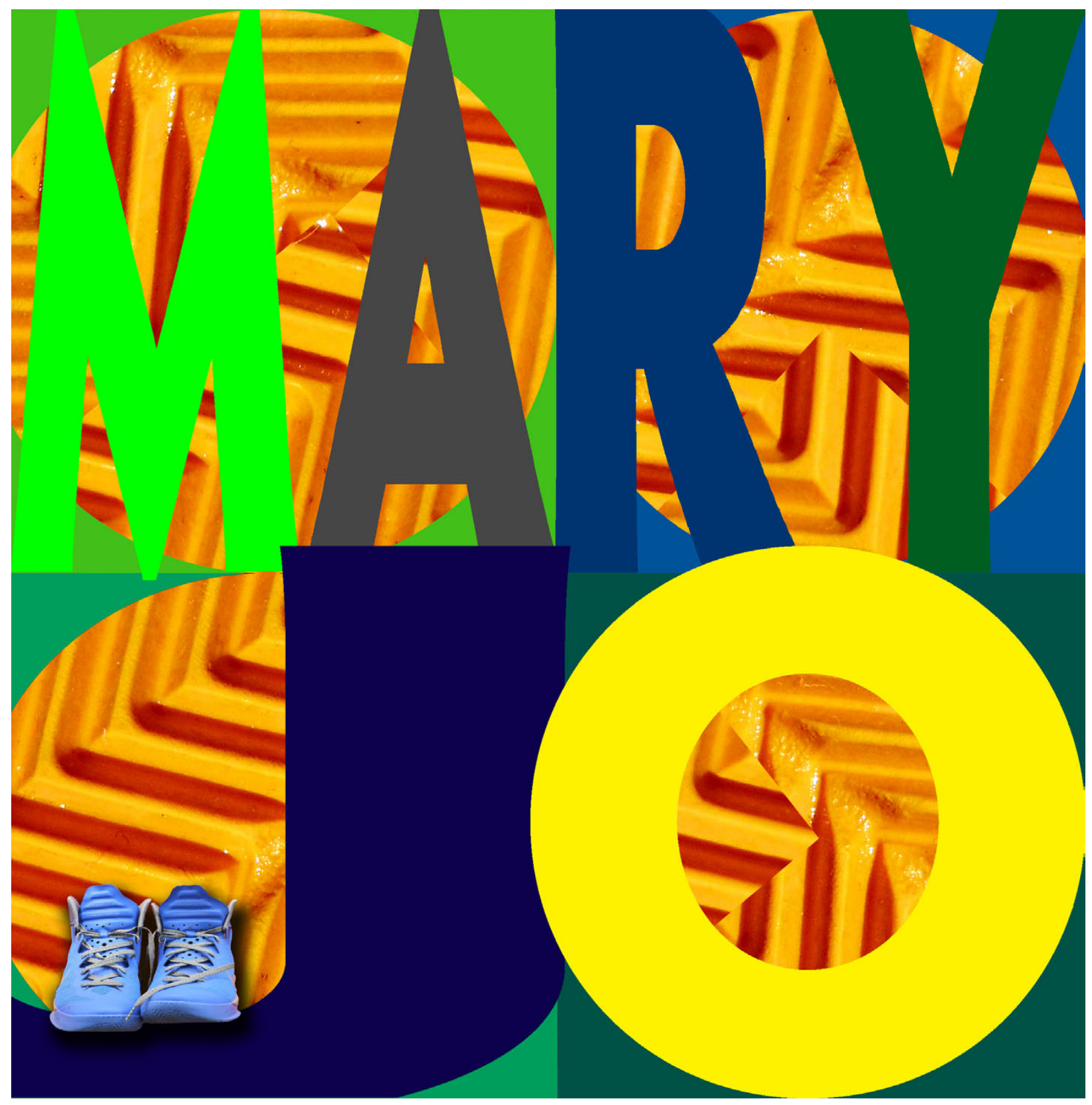

Plate 20. Day 119 - MARY JO, Pattern Study, No. 27 (digital collage) 


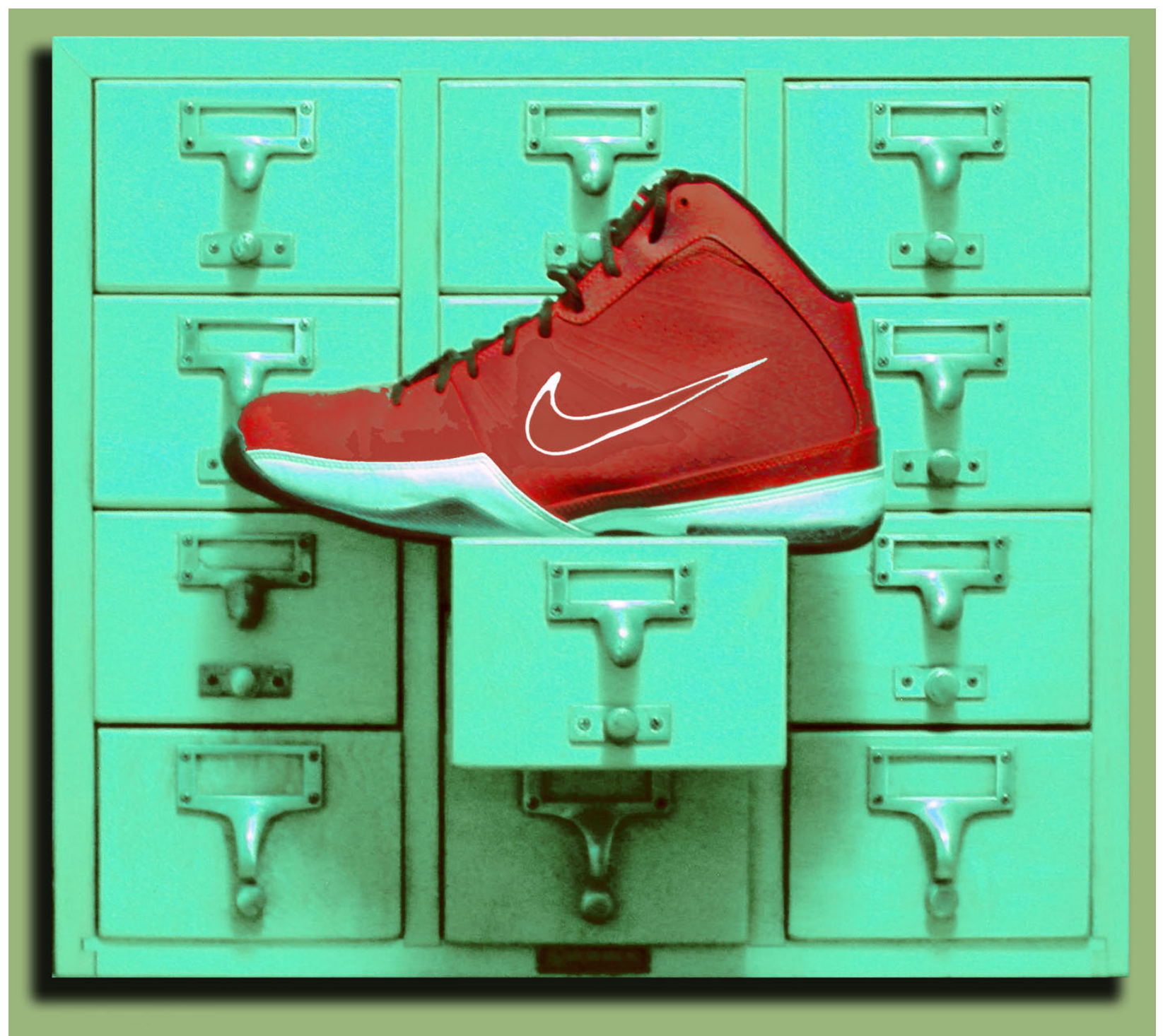

Plate 21. Day 138 - Still Life, No. 16 


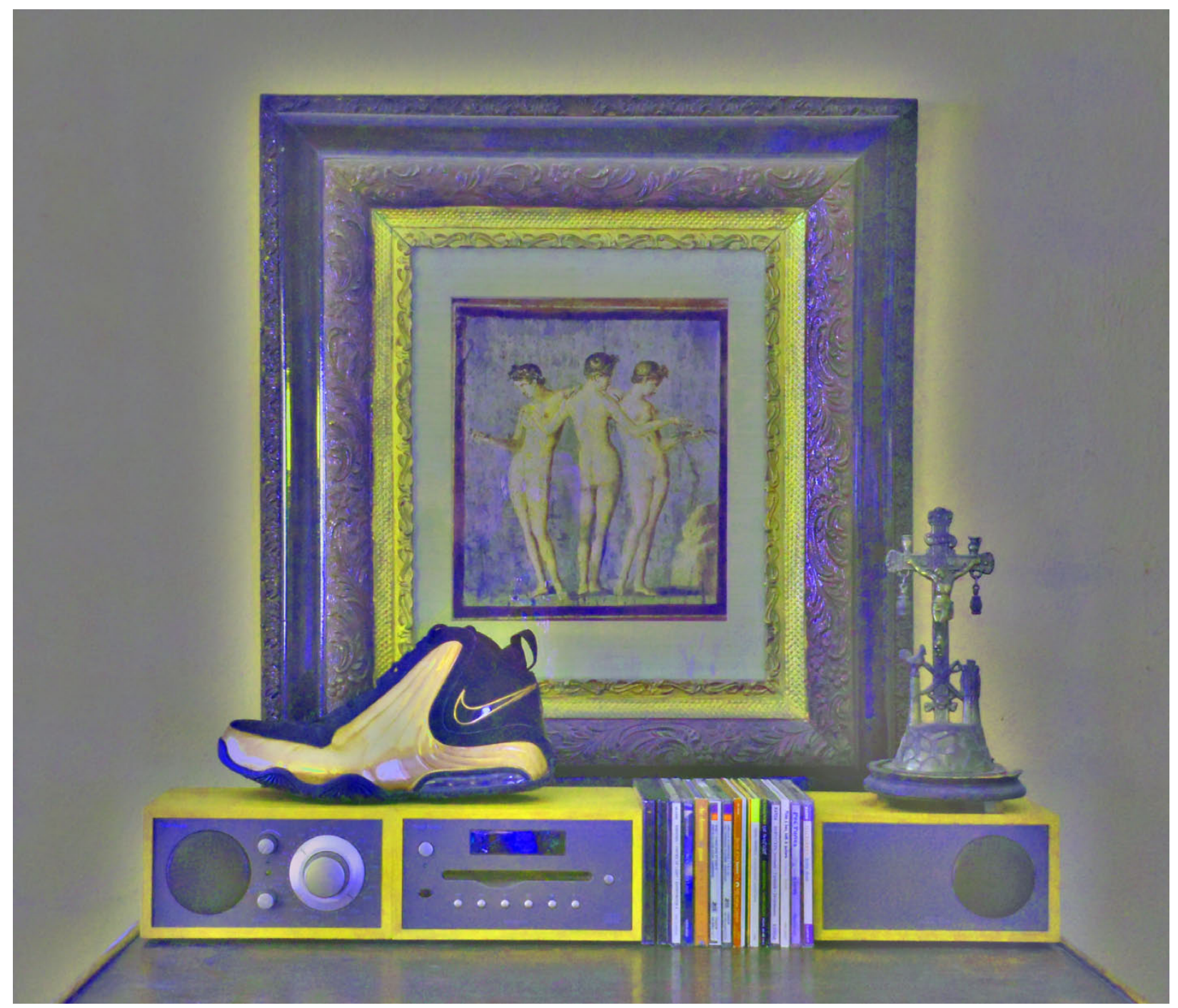

Plate 22. Day 139 - Still Life, No. 17 


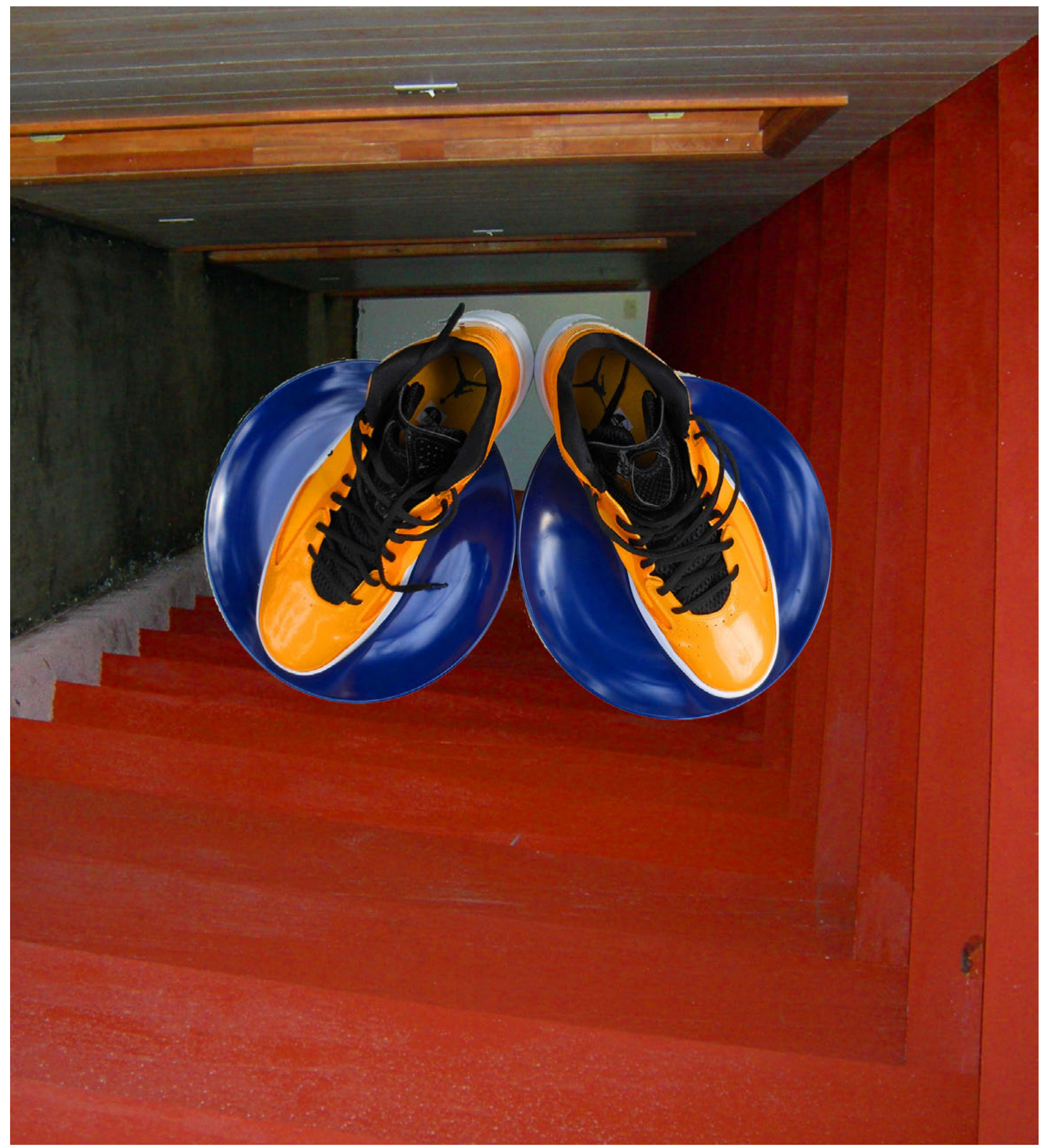

Plate 23. Day 154 — Former Snowflake Motel, Stevensville, Michigan (digital collage) 


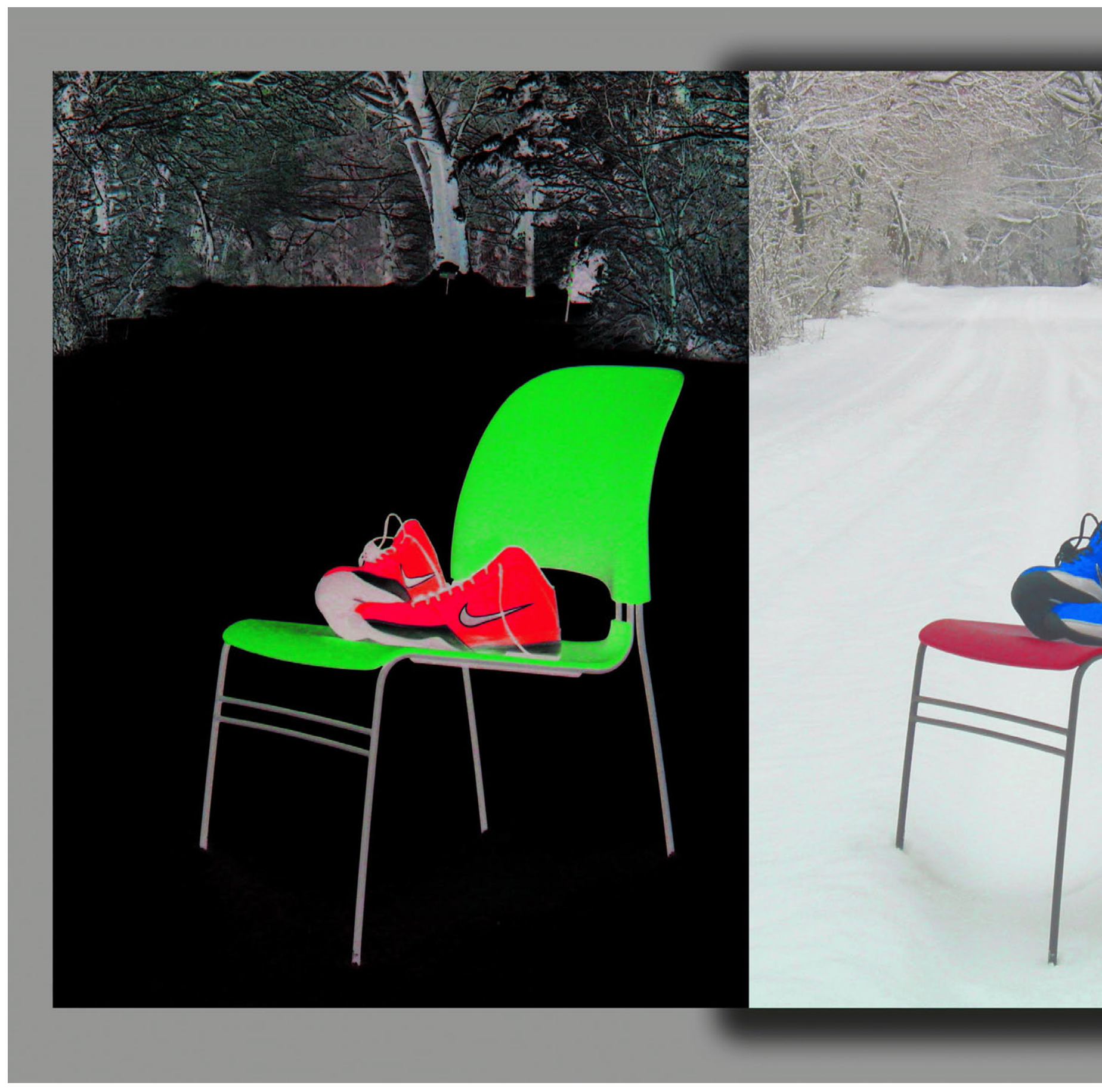

Plate 24. Day 159 - Winter Triptych, Mizpah Park, Michigan (digital collage) 


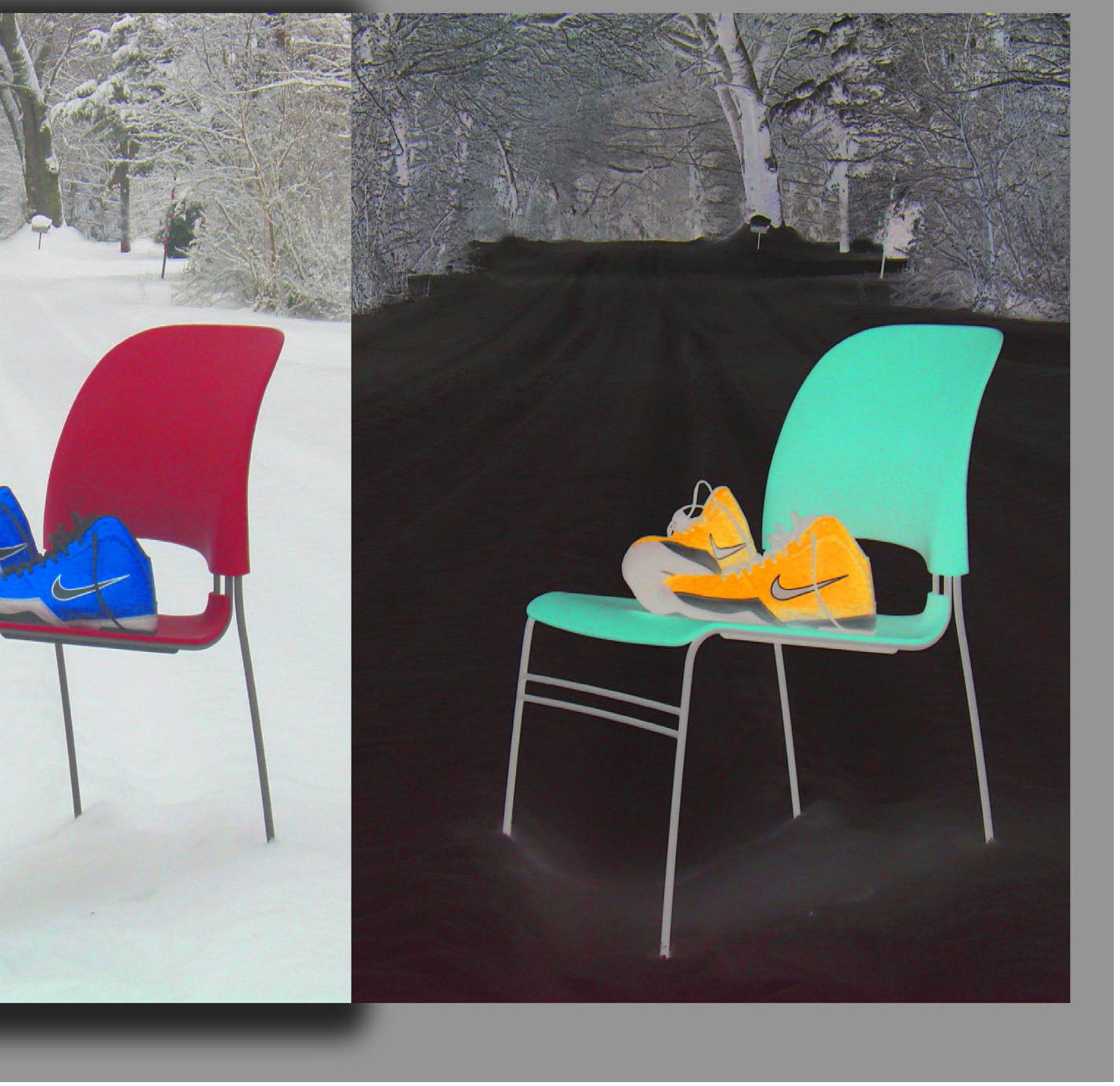




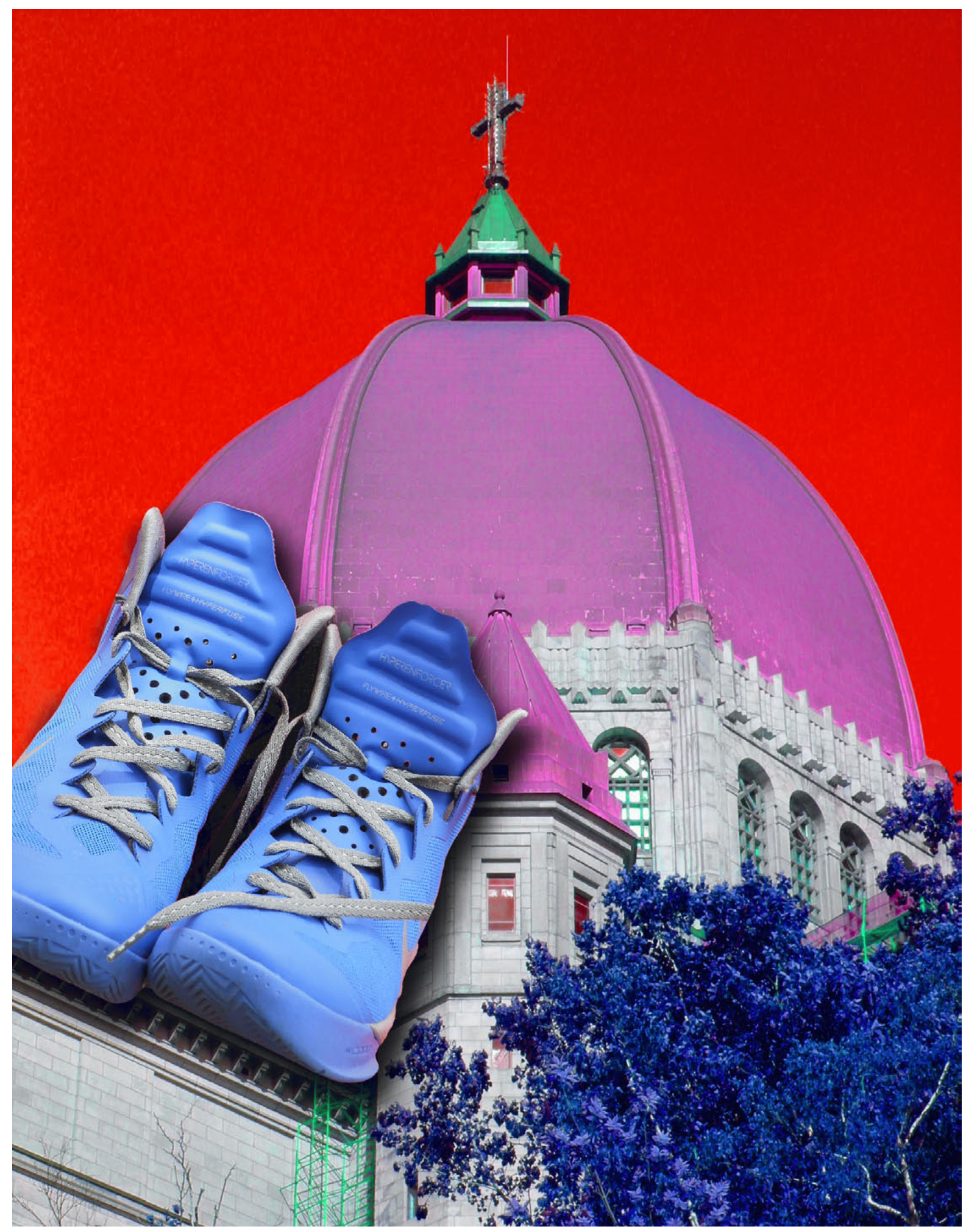

Plate 25. Day 165 - St. Joseph's Oratory, Montreal, Canada (digital collage) 


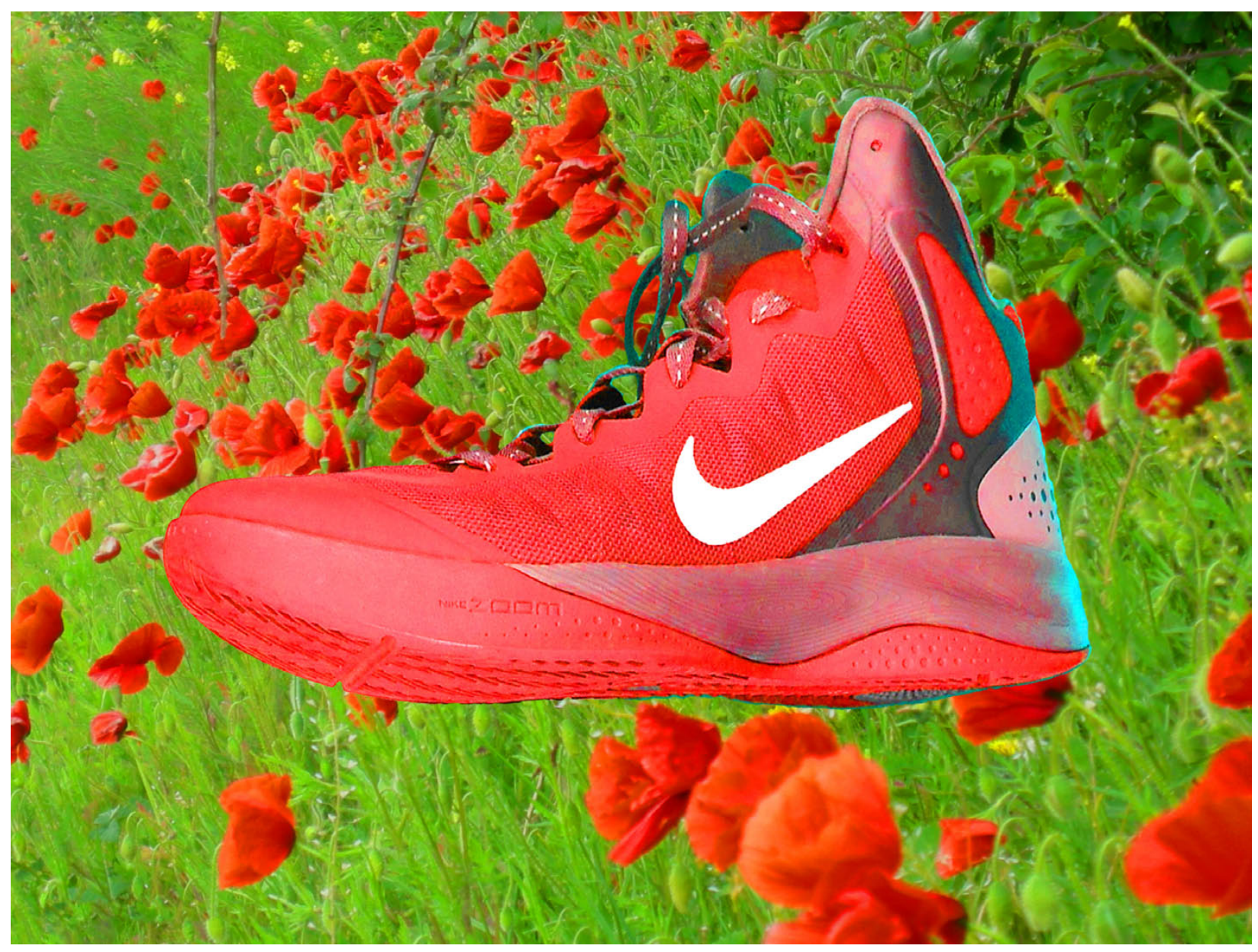

Plate 26. Day 167 — Poppy Field, Western Ireland (digital collage) 


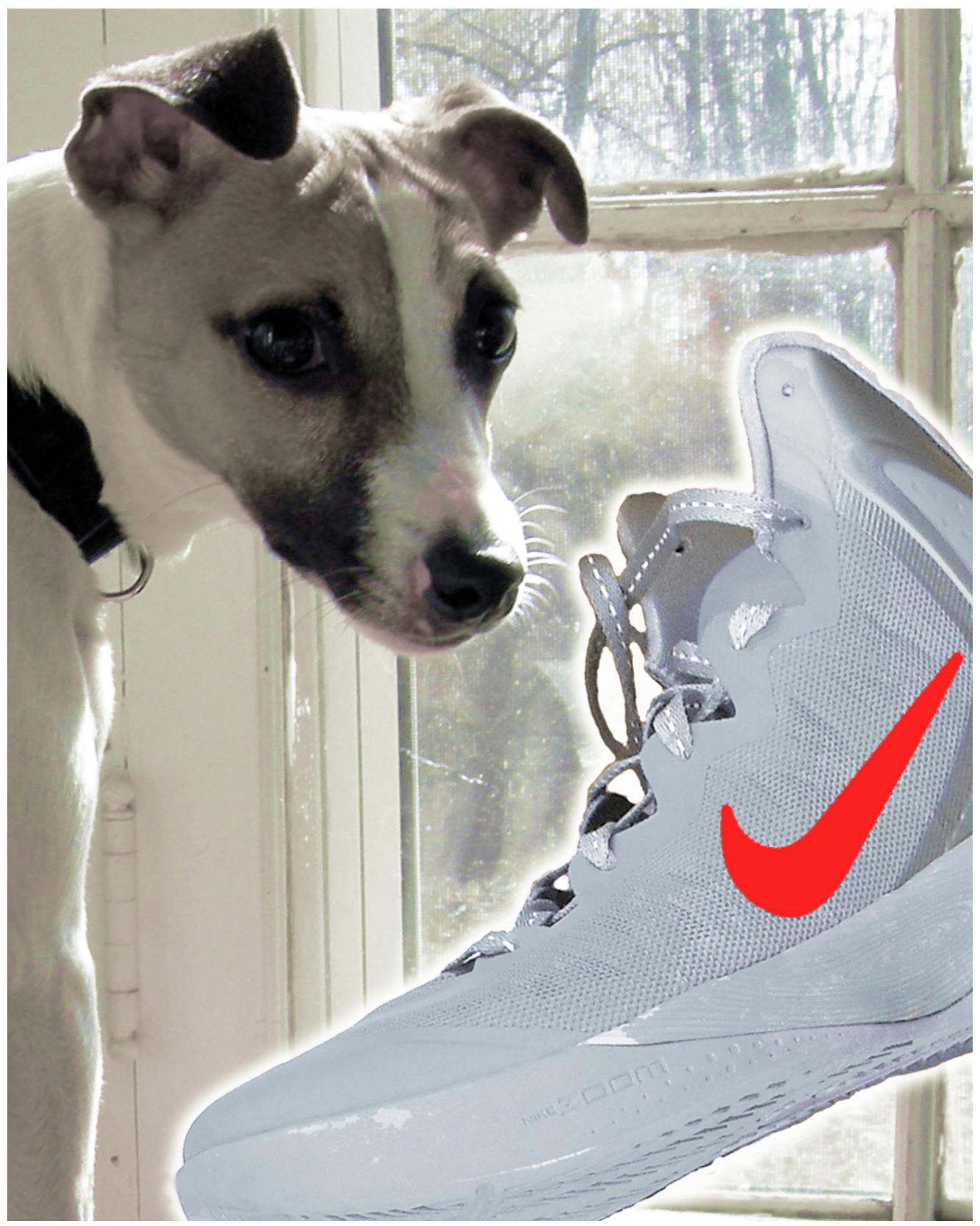

Plate 27. Day 185 — "Annie," a Jack Russell Terrier (digital collage) 


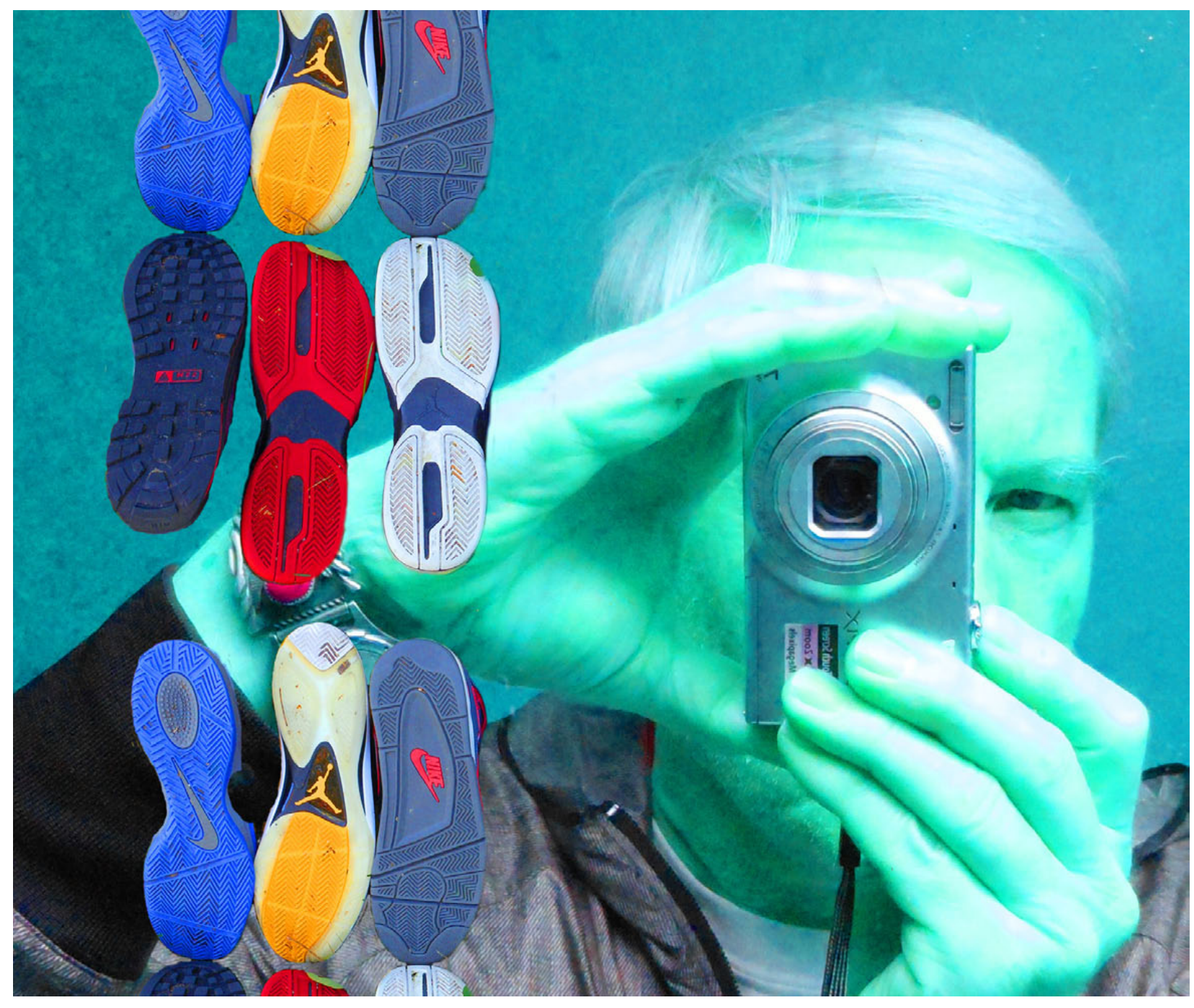

Plate 28. Day 194 - Self-Portrait (digital collage) 


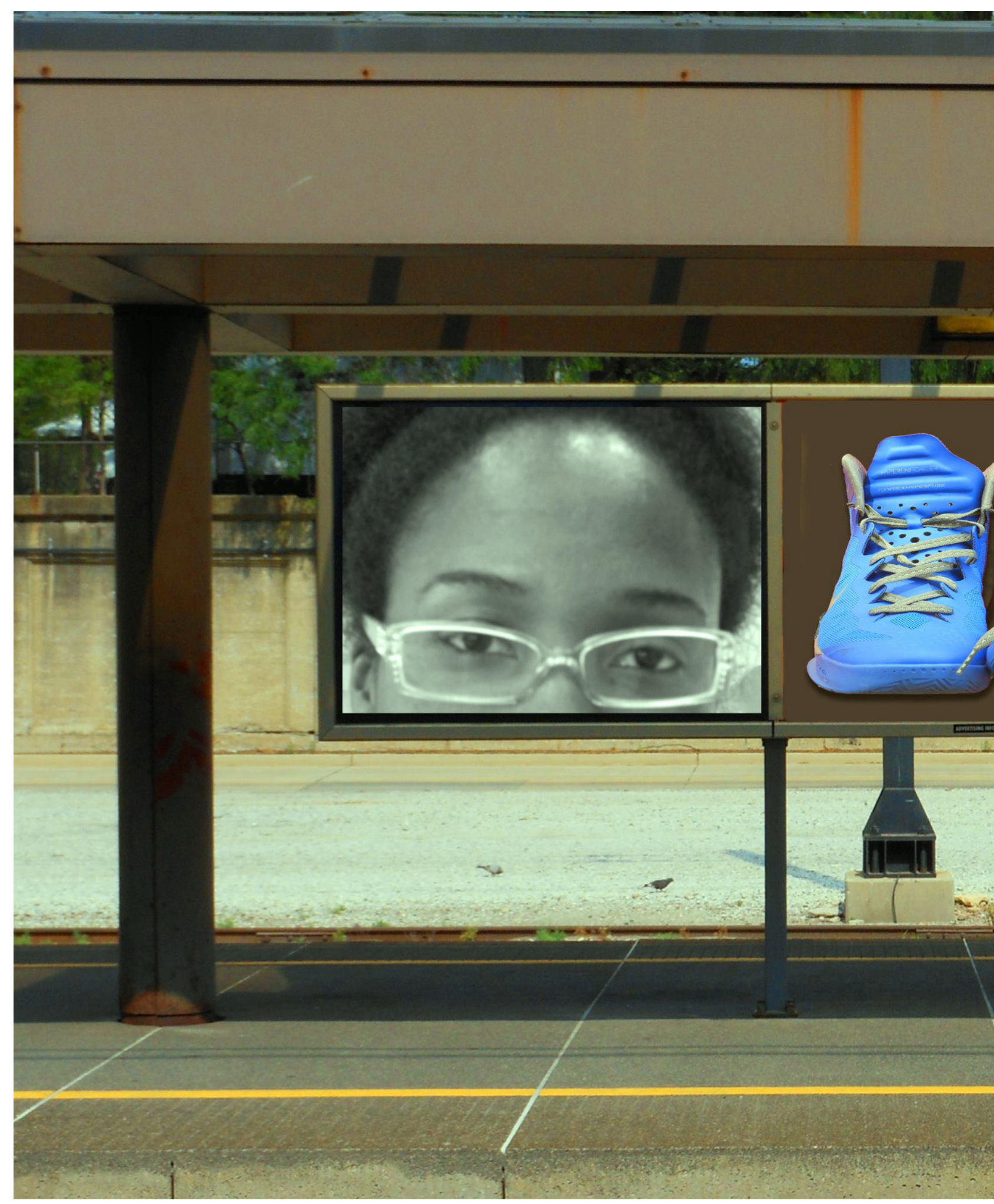

Plate 29. Day 192 - Metra Station Triptych, Chicago, Illinois (digital collage) 


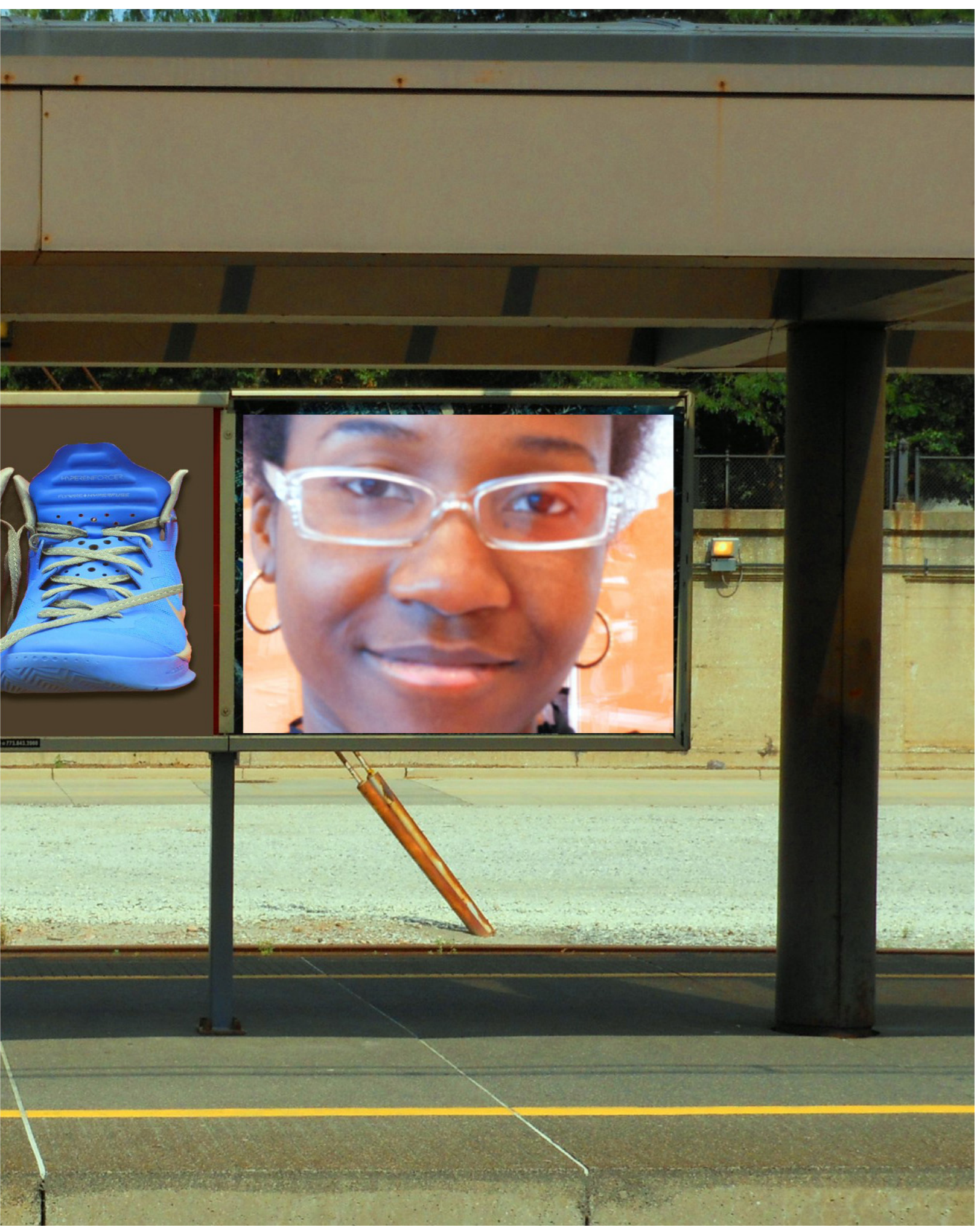




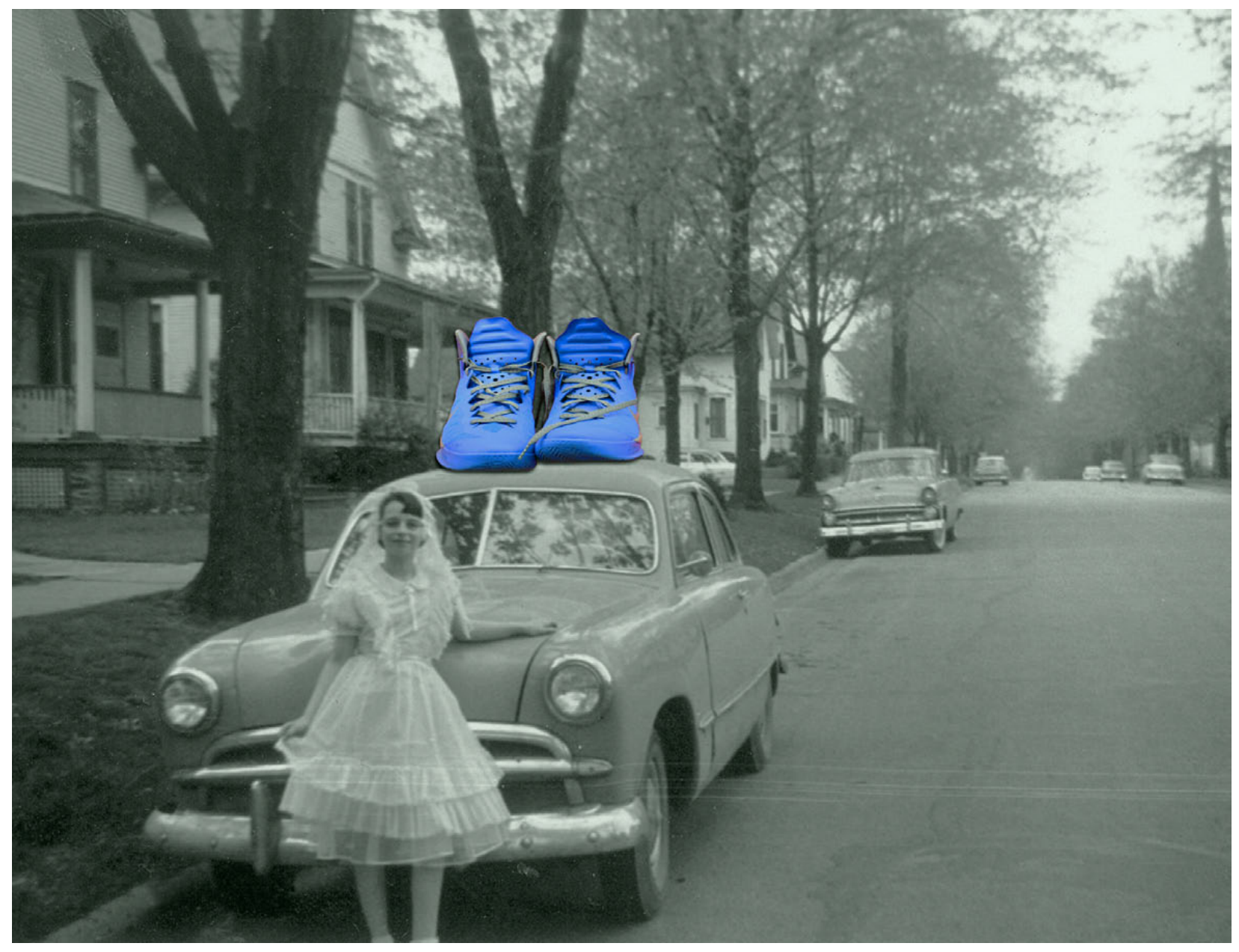

Plate 30. Day 198 - Vintage Family Photograph (digital collage) 


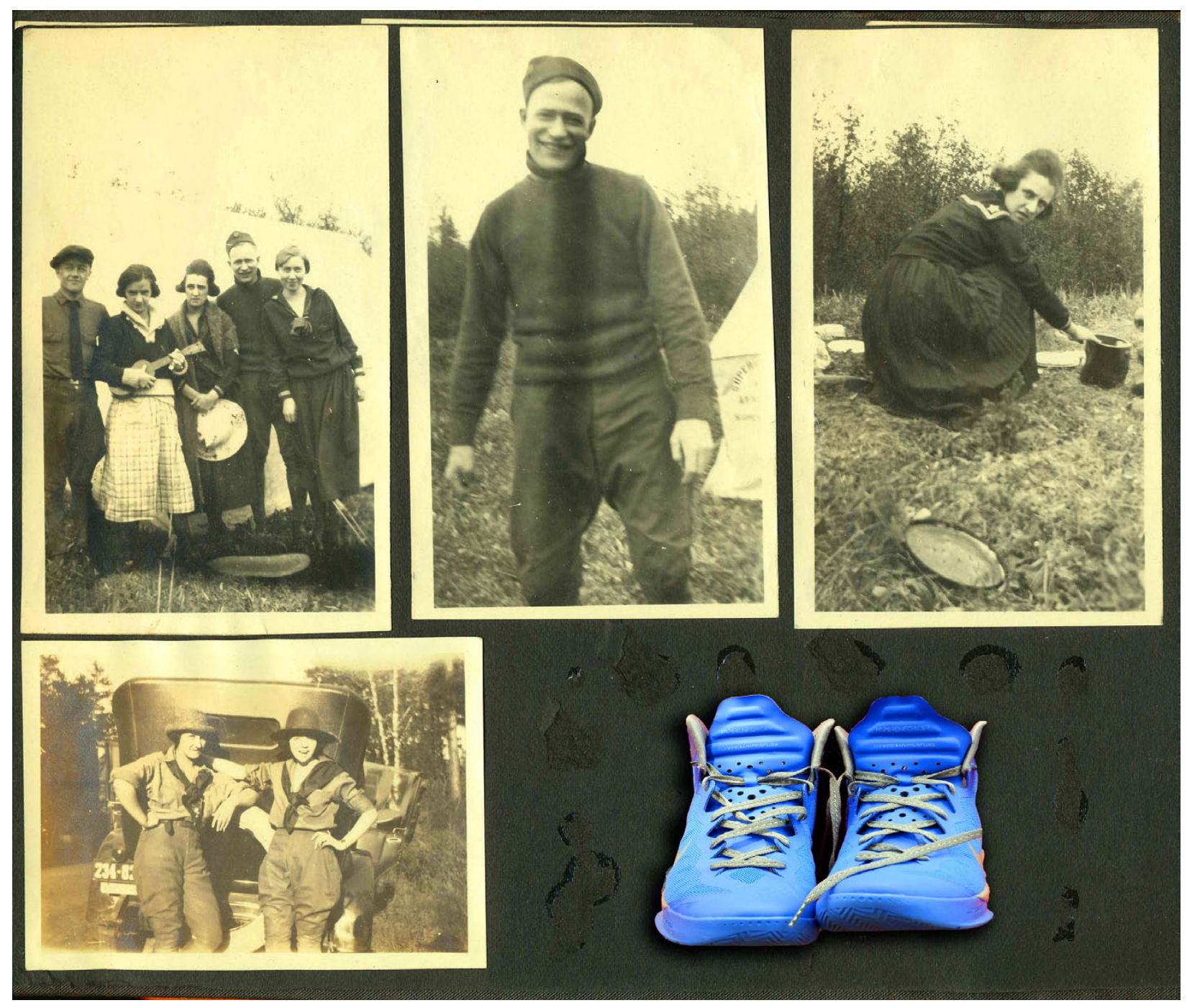

Plate 31. Day 204 - Page from Vintage Photograph Album (digital collage) 


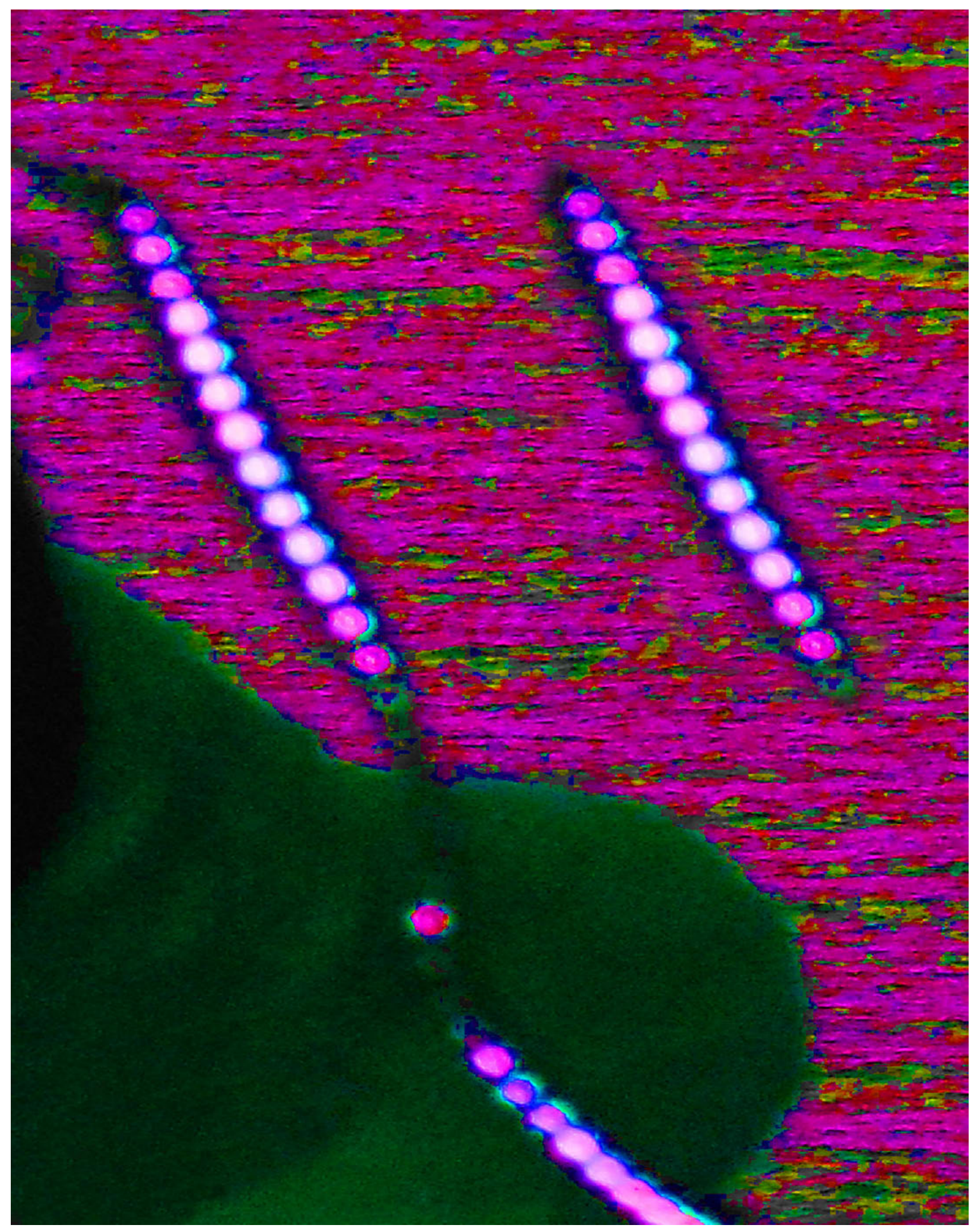




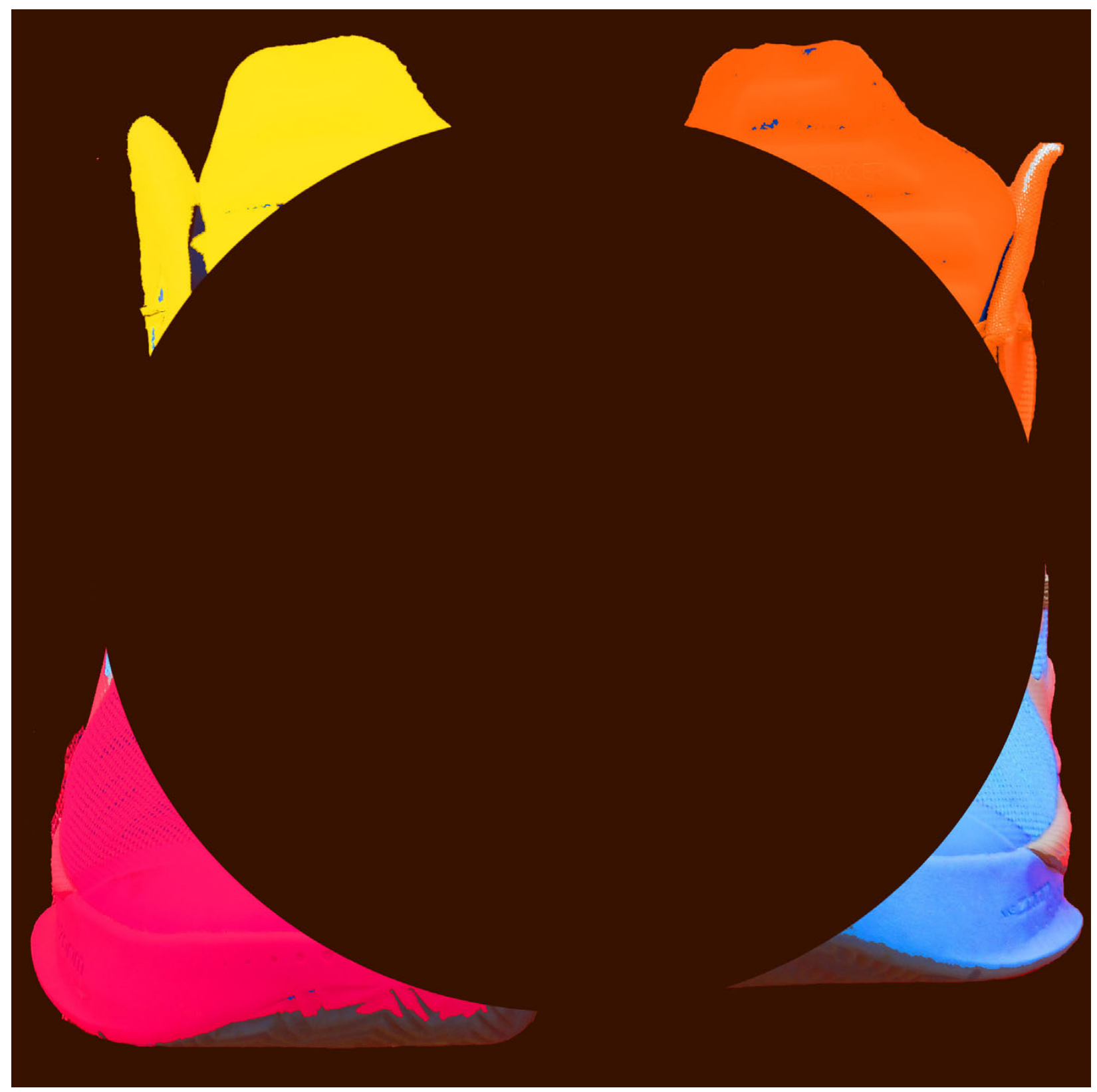

Plate 33. Day 231 - Abstraction, No. 19

\section{Opposite page}

Plate 32. Day 214 - Abstraction, No 2 


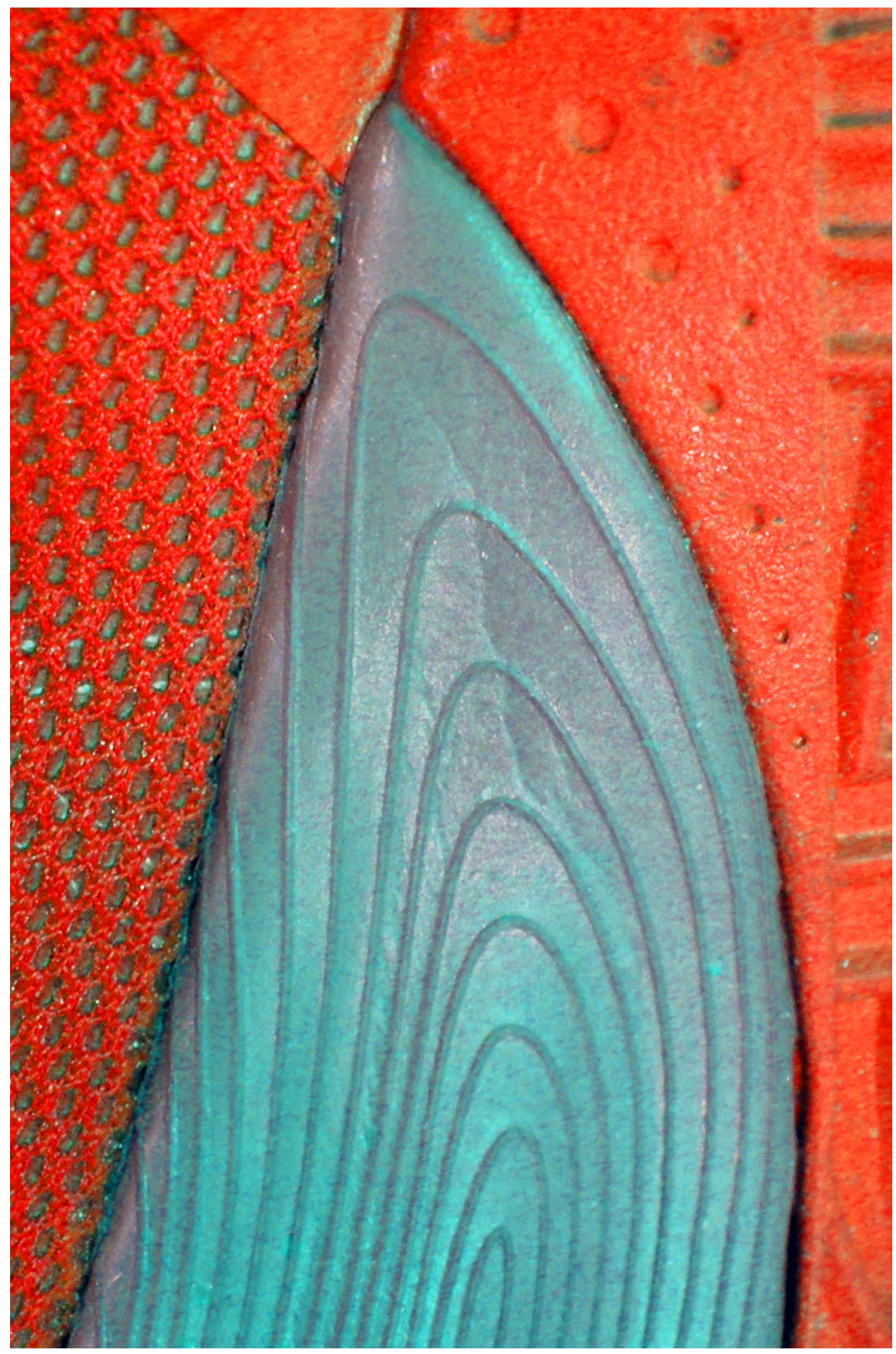




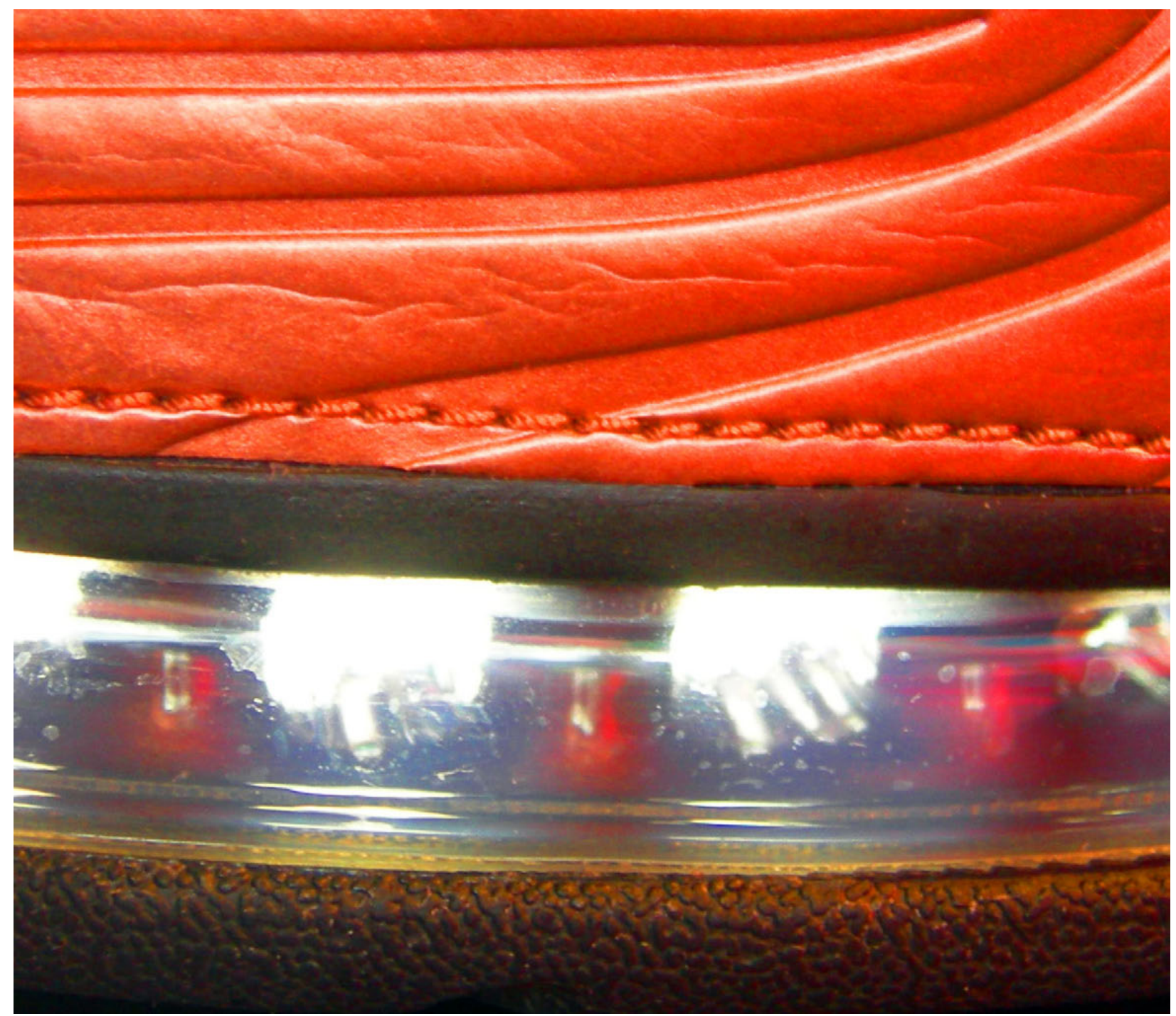

Plate 35. Day 255 - Close-Up, No. 12

\section{Opposite page}

Plate 34. Day 246 - Close-Up, No. 3 


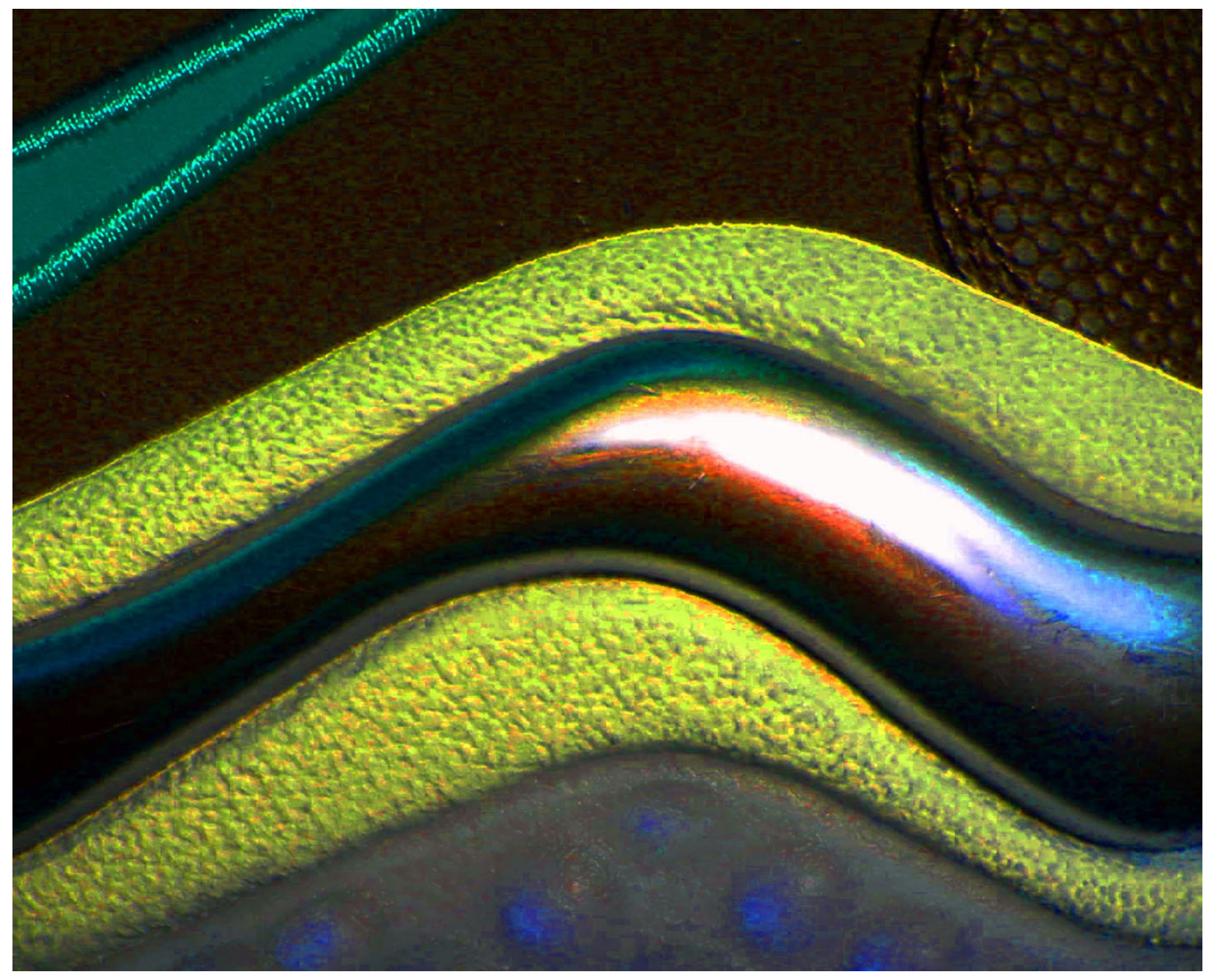

Plate 36. Day 226 - Close-Up, No. 23 


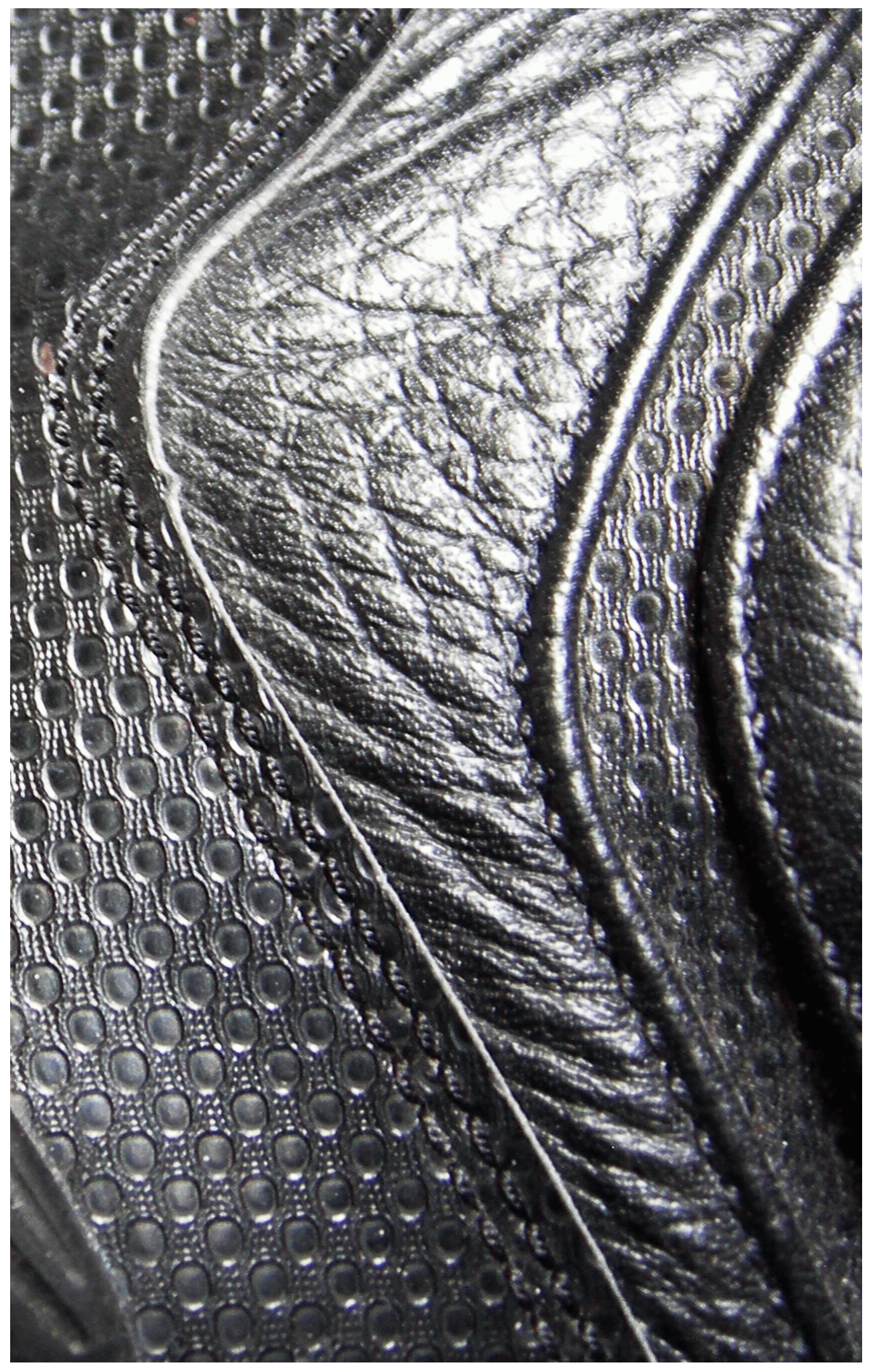




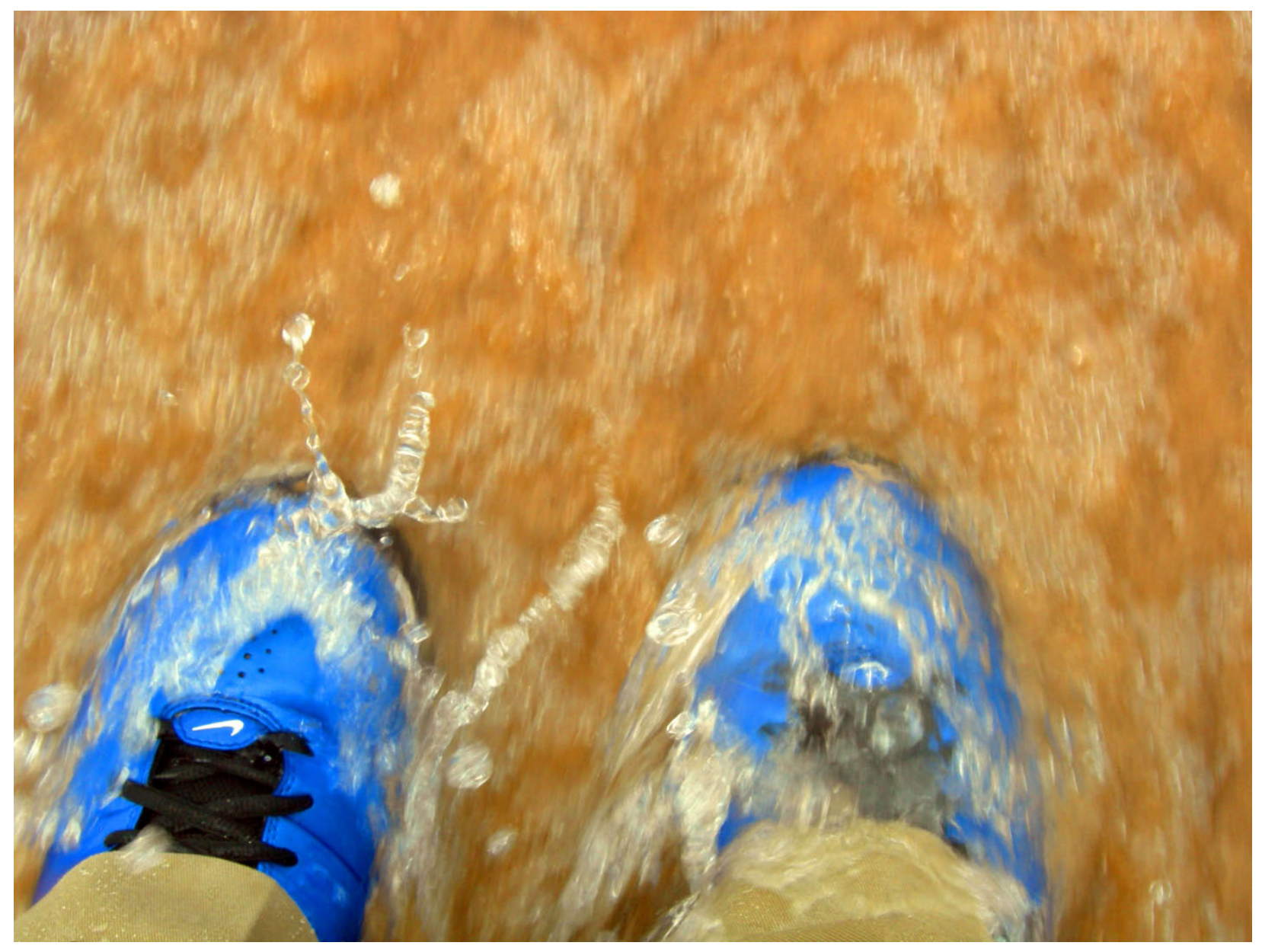

Plate 38. Day 290 — Feet On the Ground, No. 16, South Beach, South Haven, Michigan 


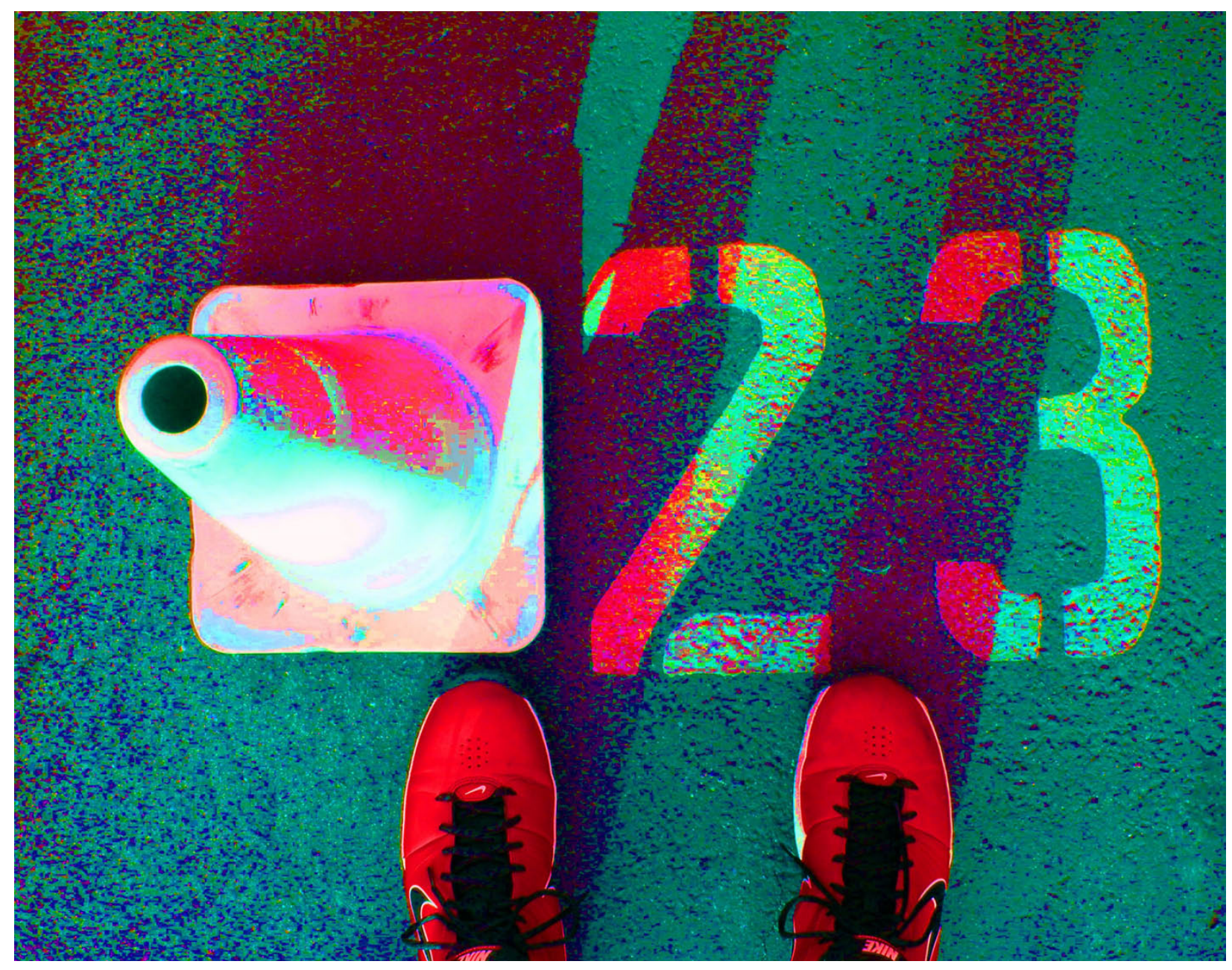

Plate 39. Day 295 — Feet On the Ground, No. 21, Parking Lot, Santa Ana, California 


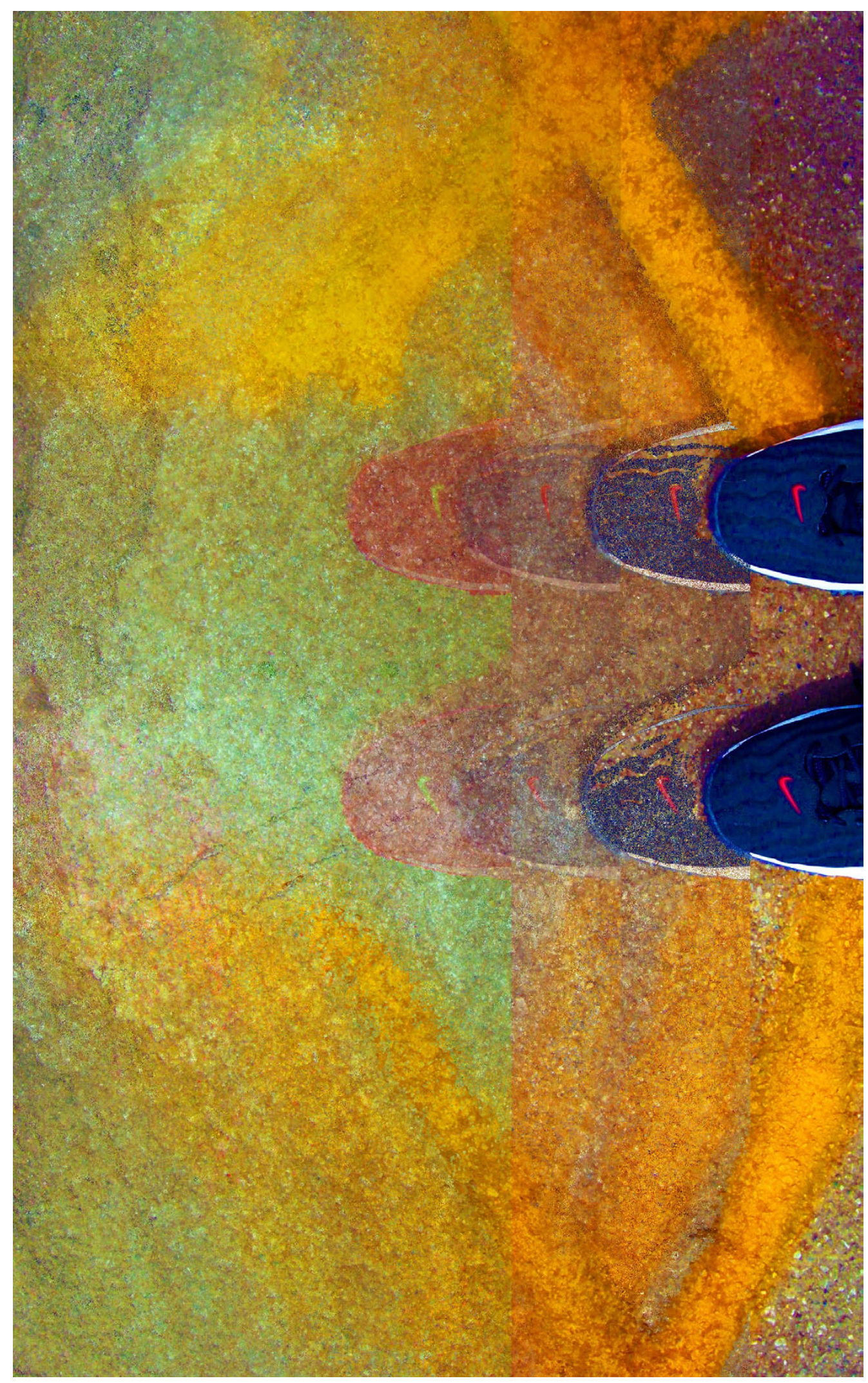




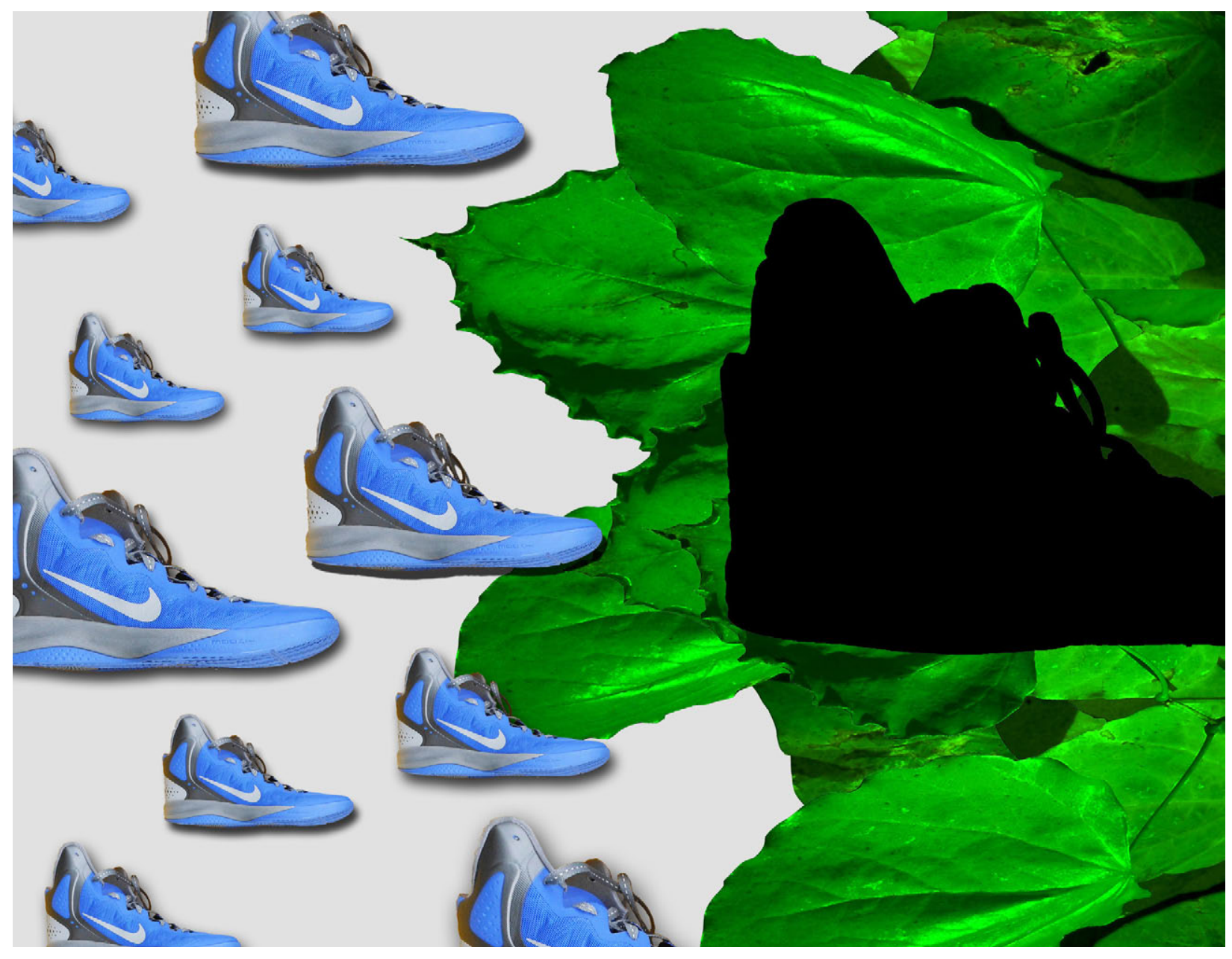

Plate 41. Day 318 - Surrealism Series, No. 2 (digital collage)

\section{Opposite page}

Plate 40. Day 302 - Feet On the Ground, No. 28, St. Joseph, Michigan (digital collage) 


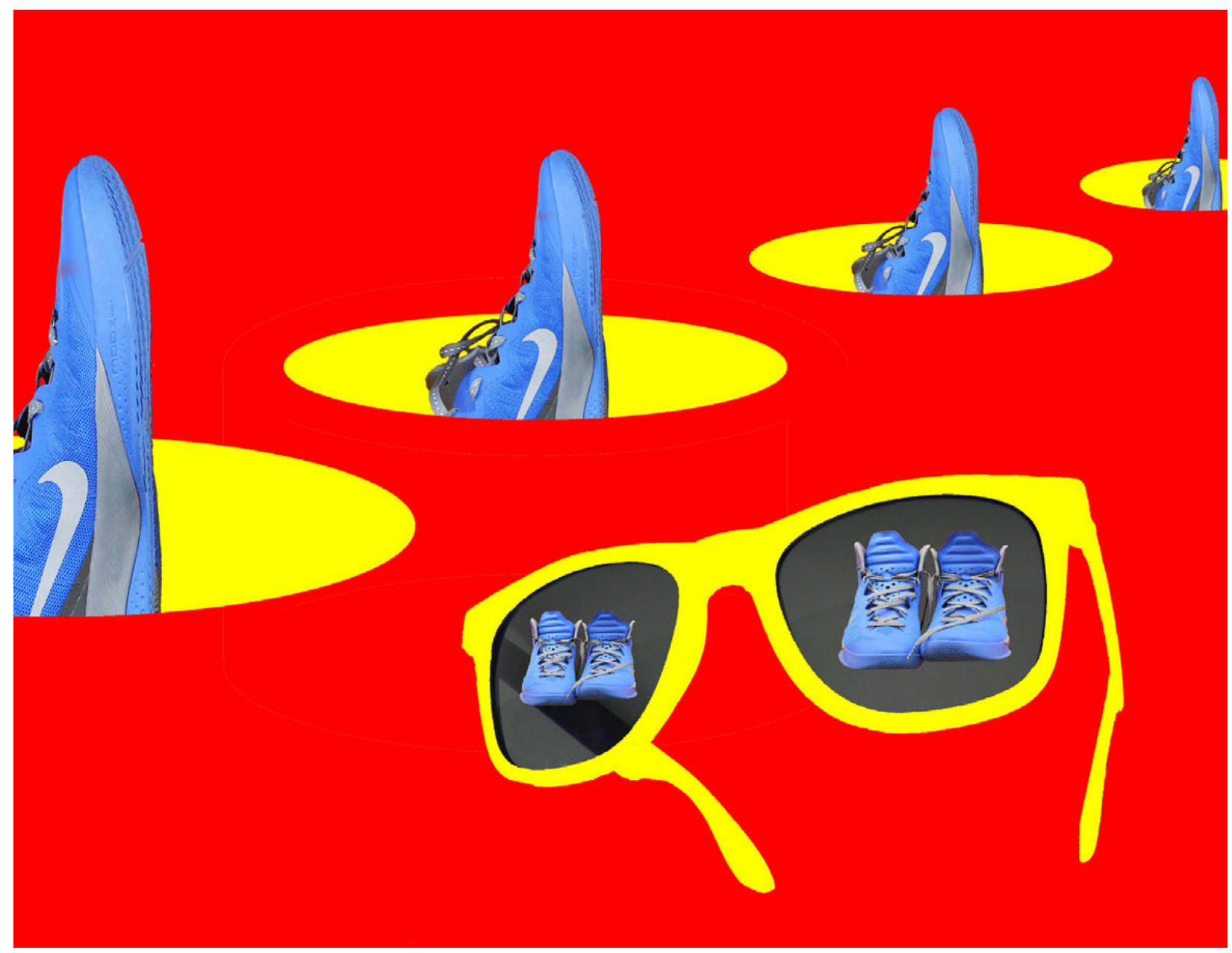

Plate 42. Day 327 — Surrealism Series, No. 11 (digital collage) 


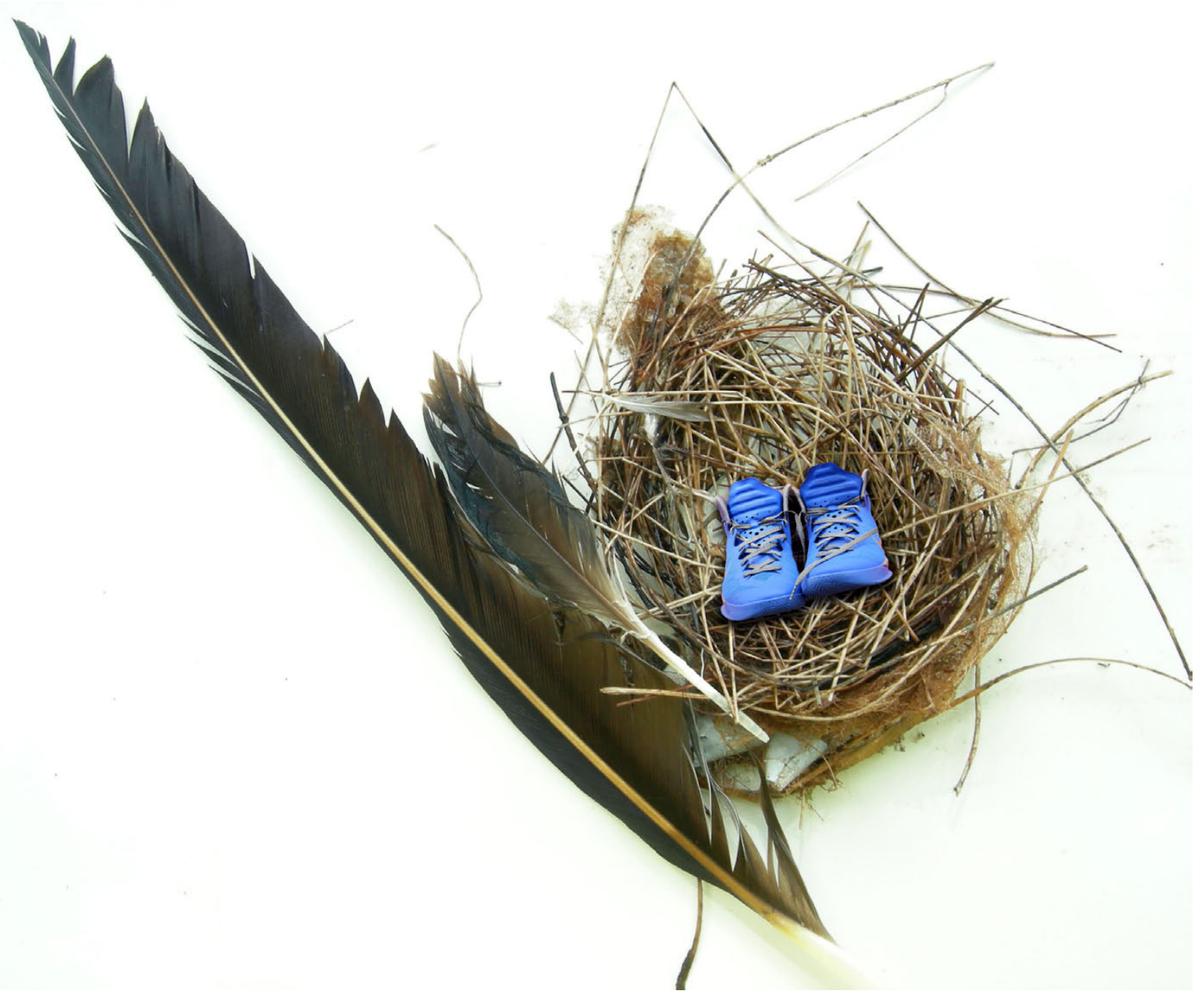

Plate 43. Day 328 - Surrealism Series, No. 12 (digital collage) 


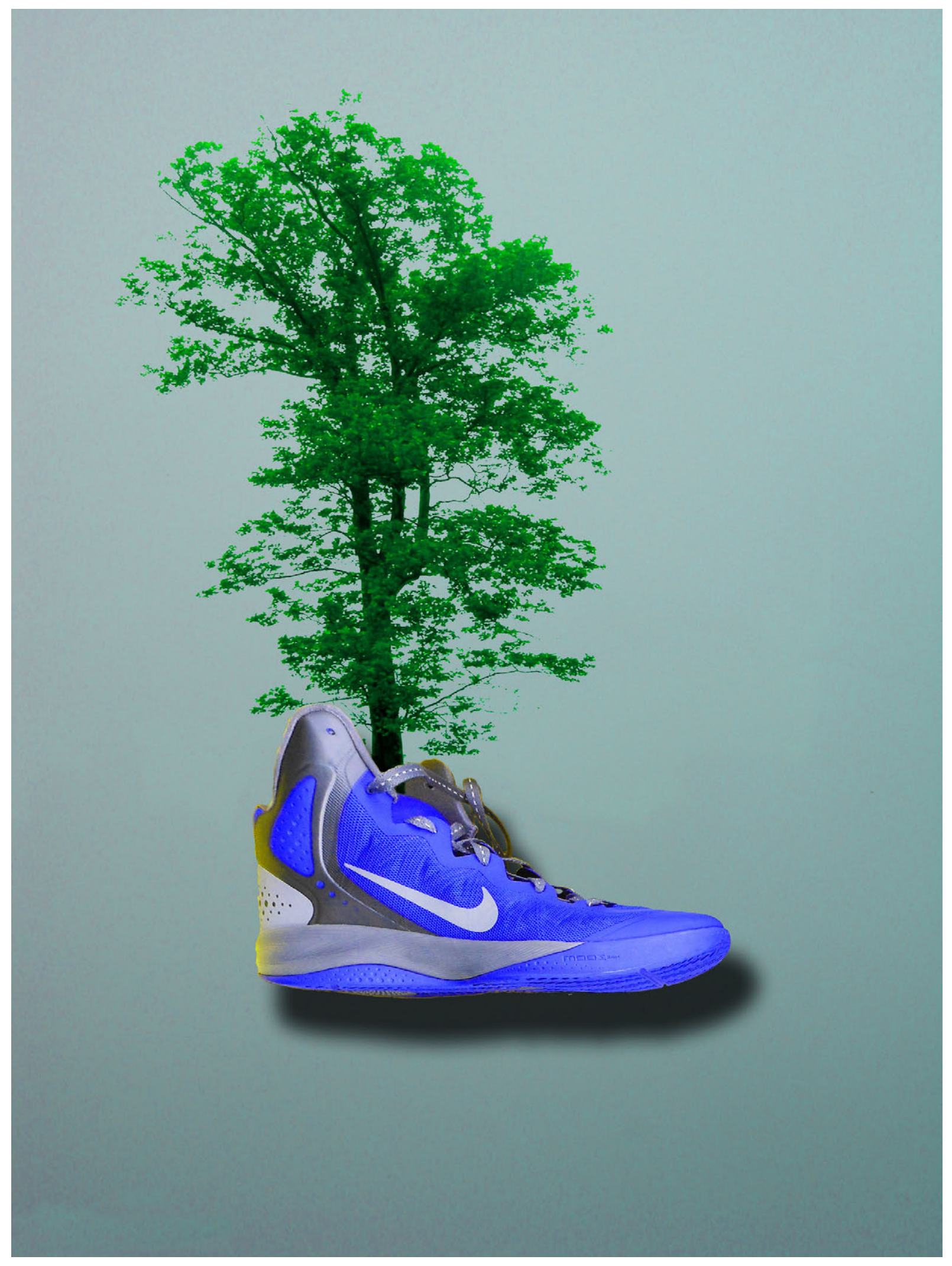




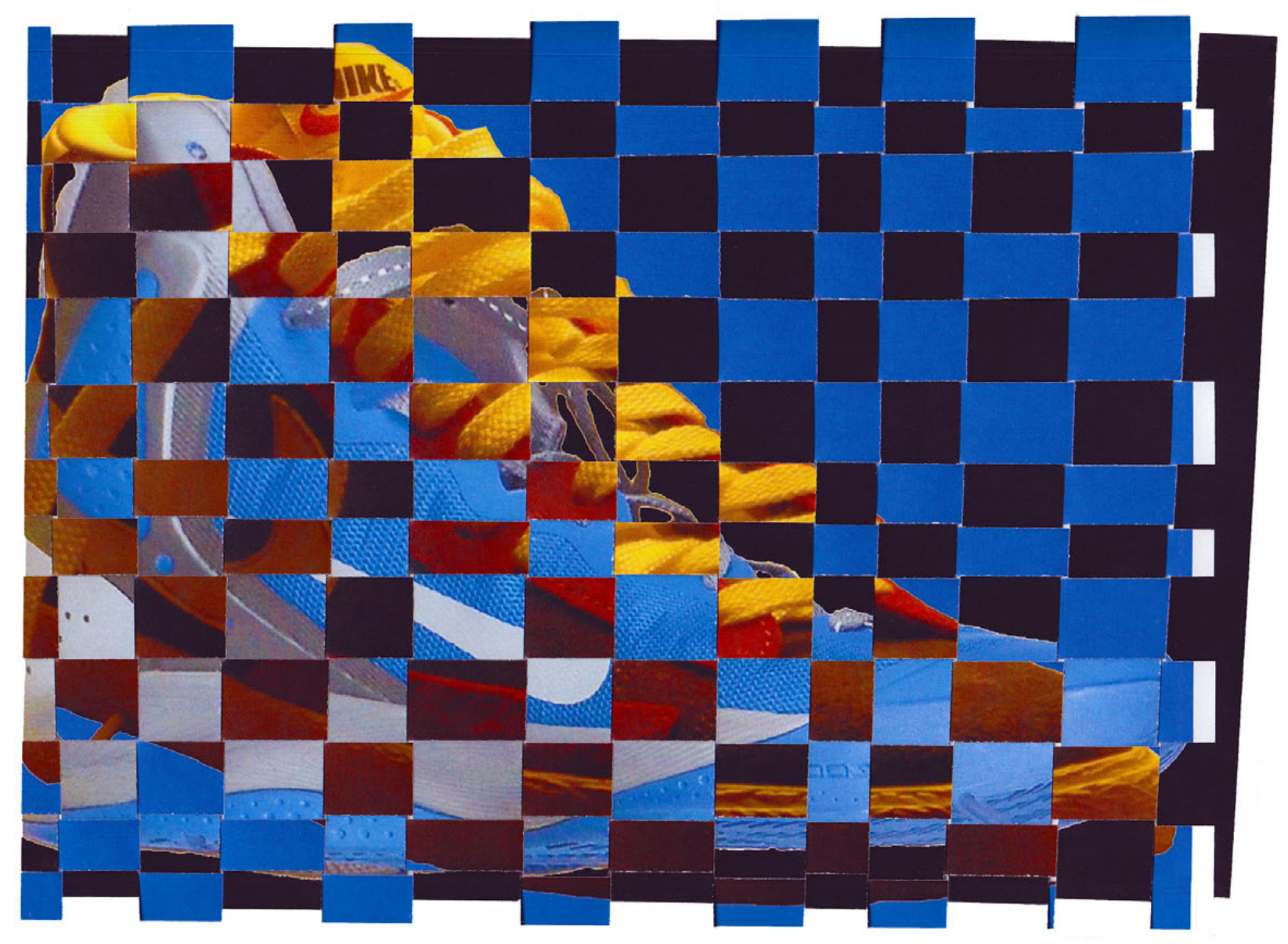

Plate 45. Day 334 - Surrealism Series, No. 18 (photograph of woven photographs)

\section{Opposite page}

Plate 44. Day 331 - Mizpah Park Tree, Surrealism Series, No. 15 (digital collage) 


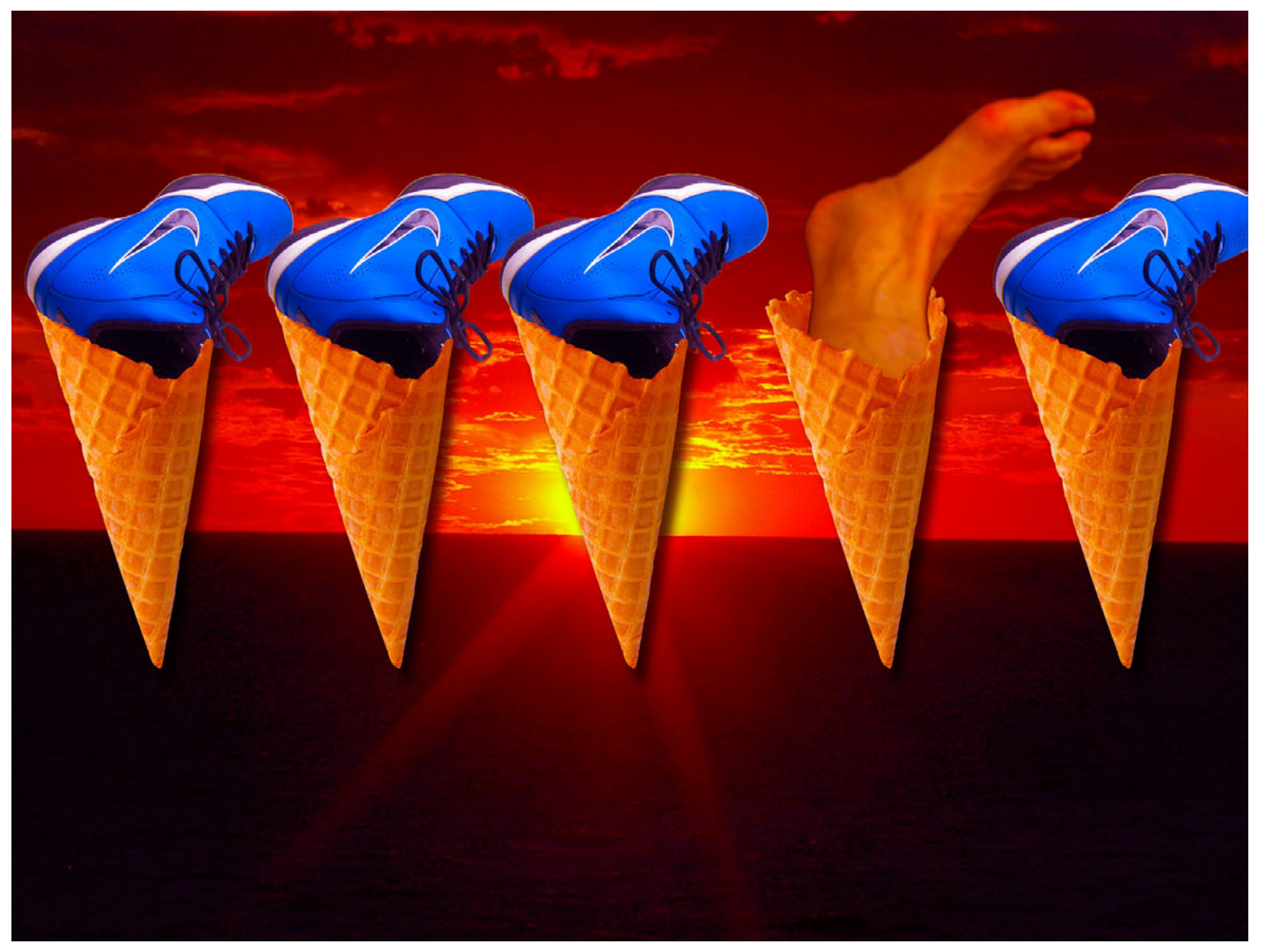

Plate 46. Day 337 — Surrealism Series, No. 21 (digital collage) 


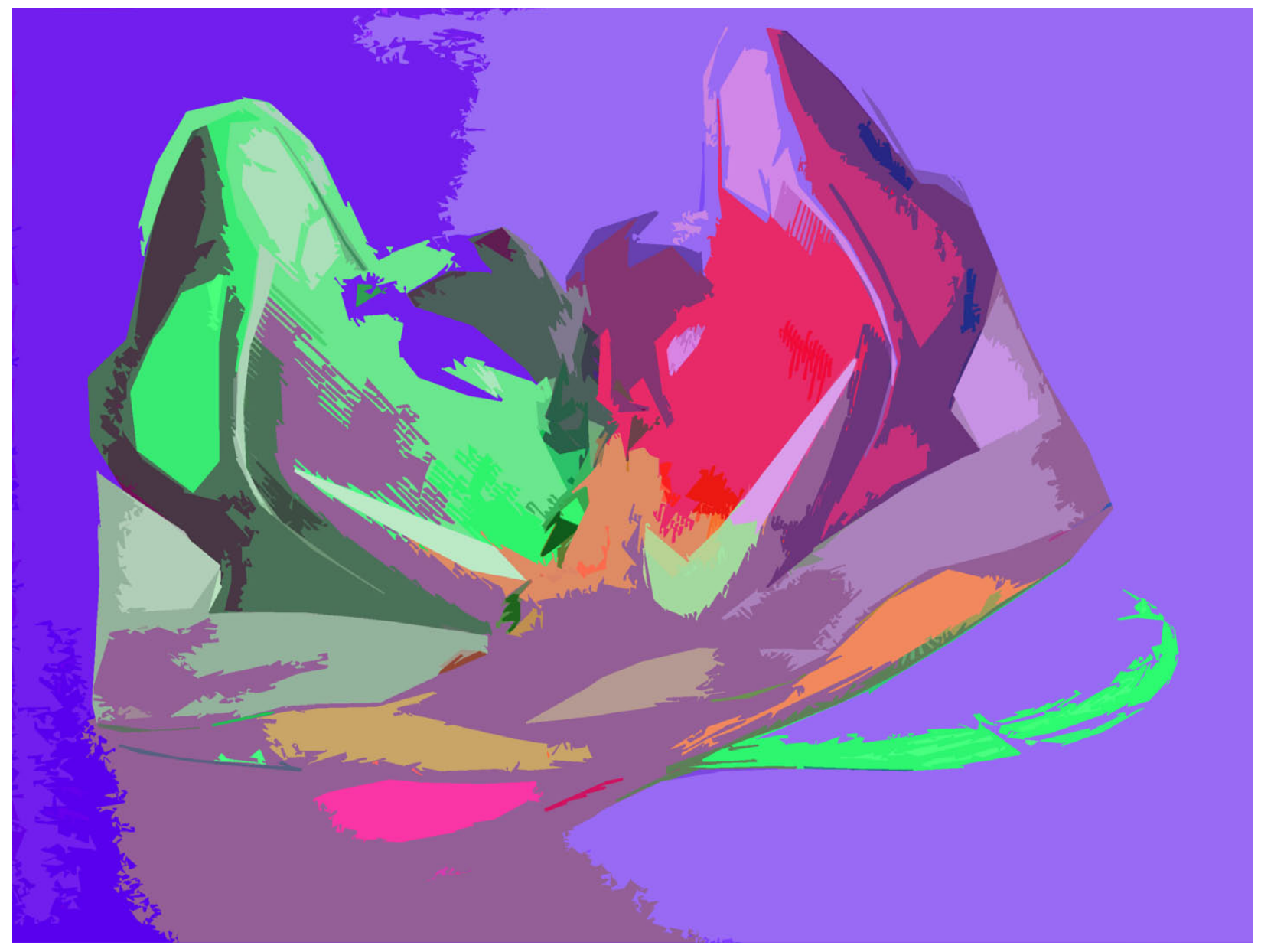

Plate 47. Day 344 - Dancing Shoes (digital collage) 


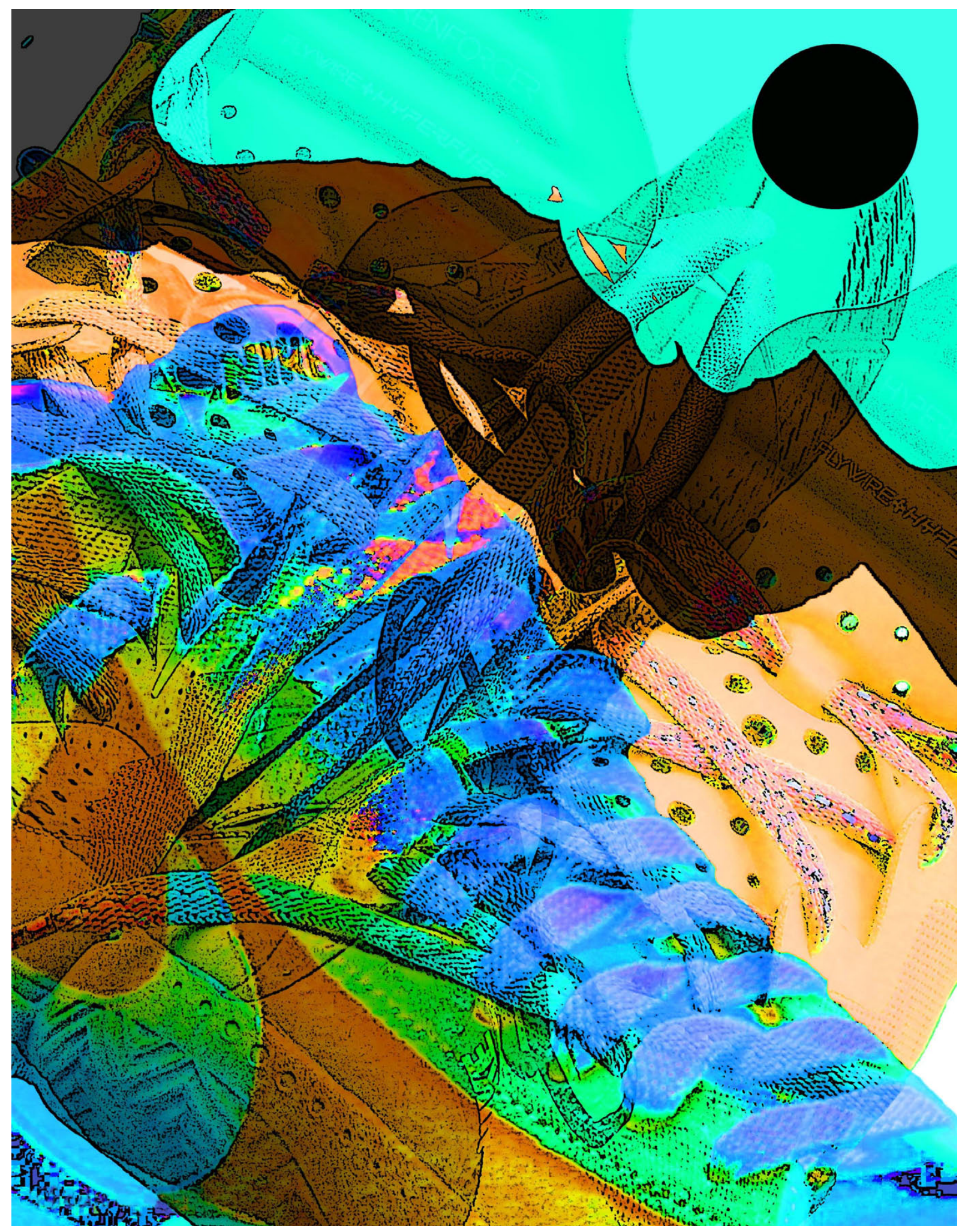

Plate 48. Day 350 - Montage (digital collage) 


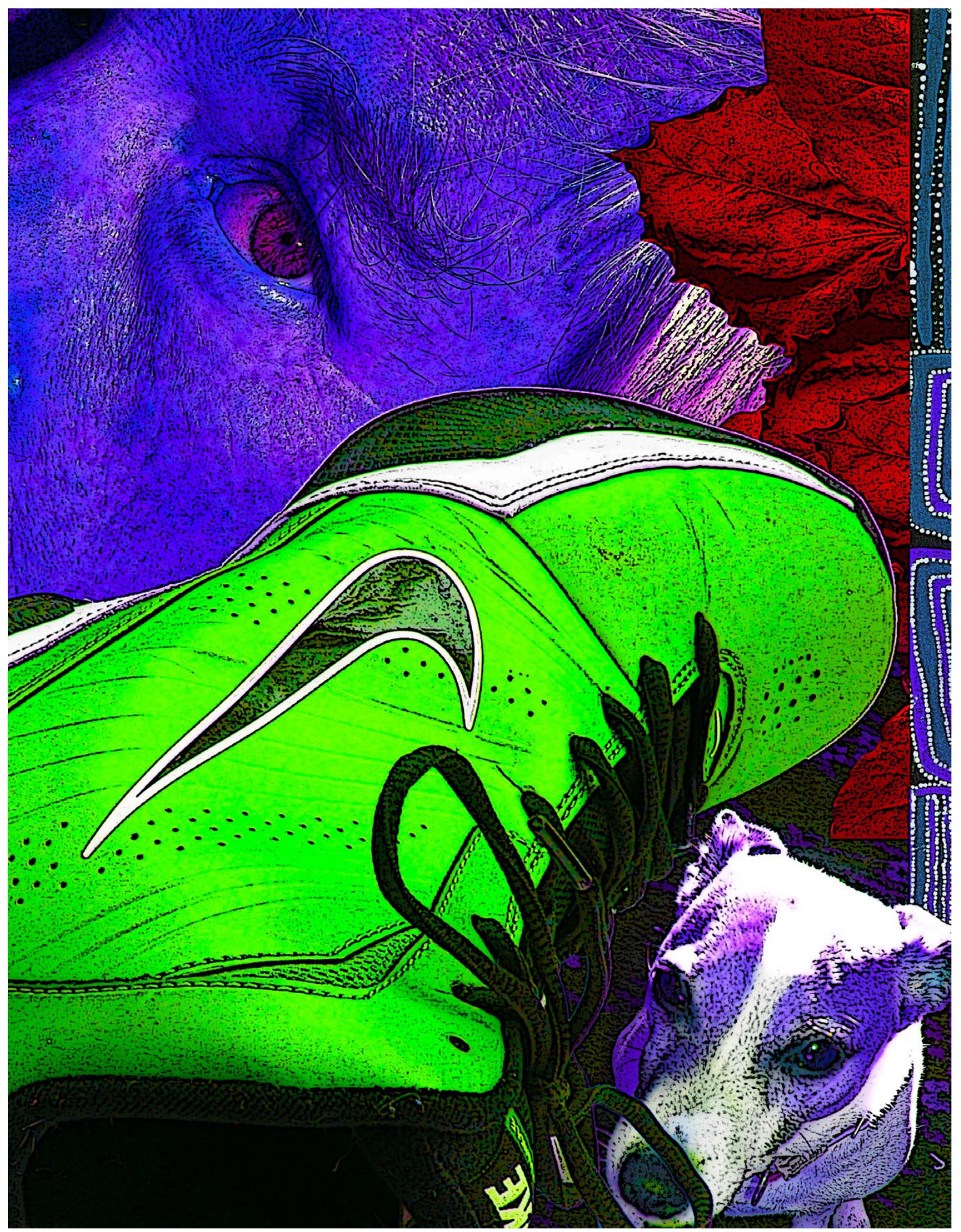

Plate 49. Day 353 - Surrealism Series, No. 31 (digital collage) 


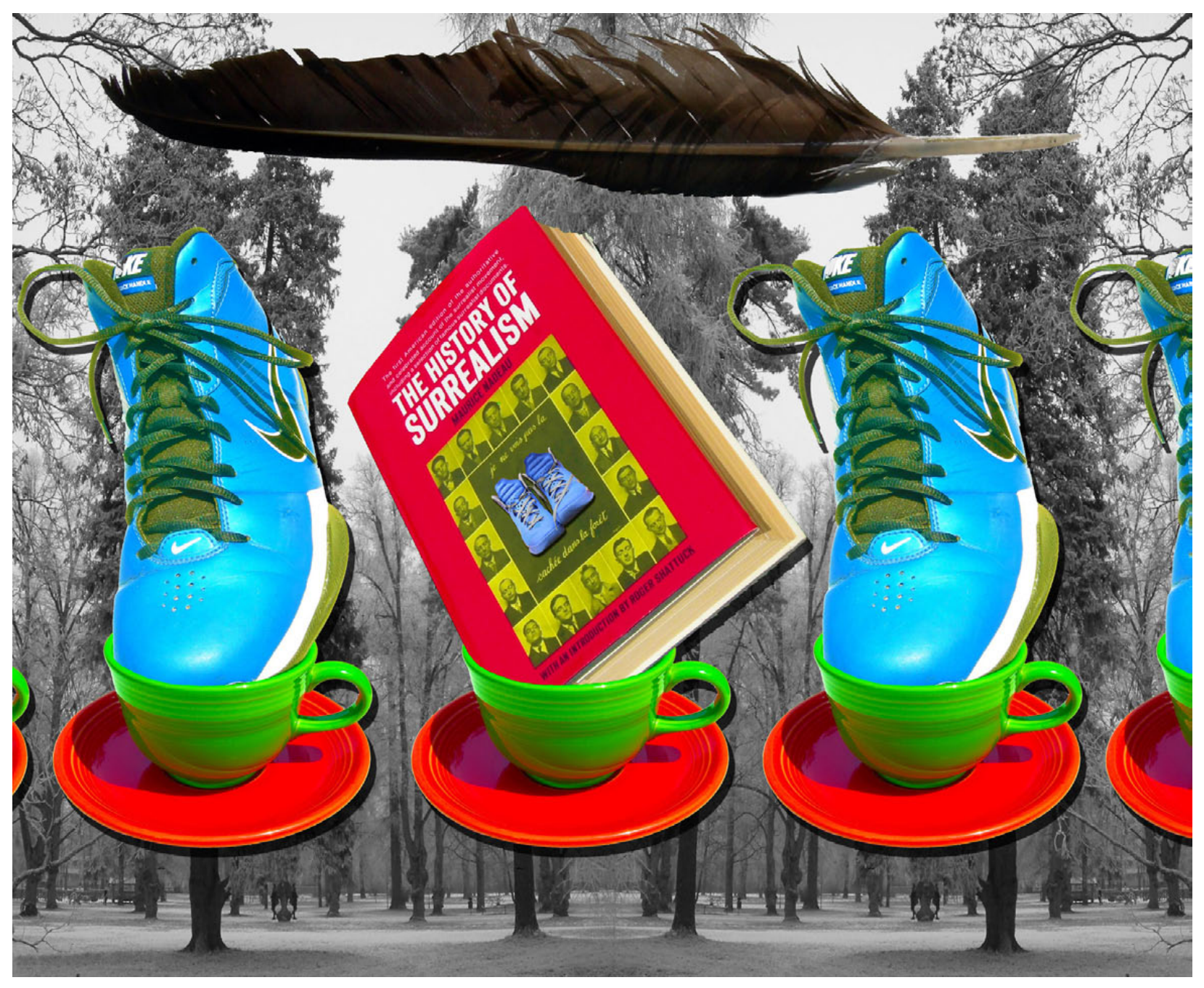

Plate 50. Day 357 - Surrealism Series, No. 35 (digital collage) 


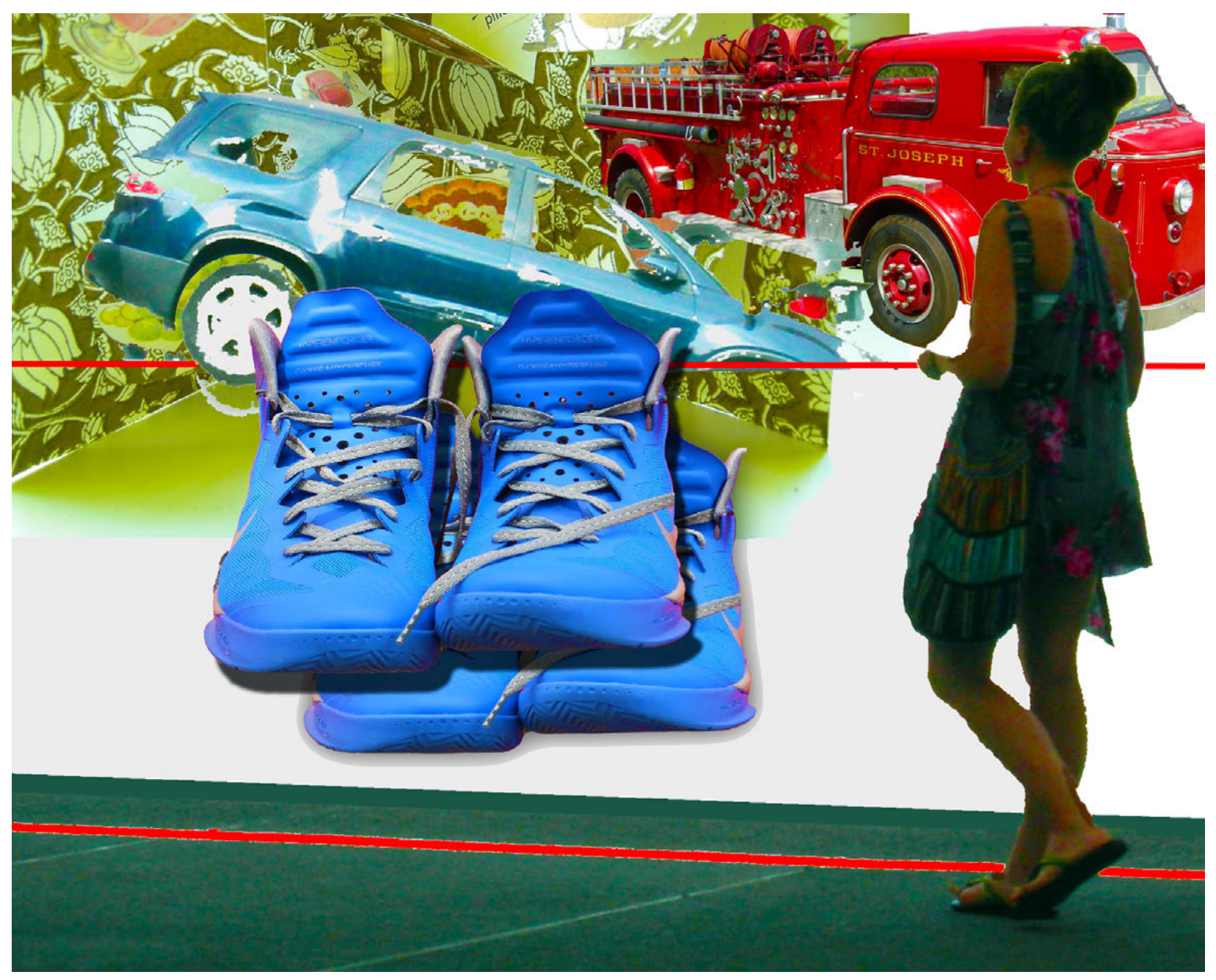

Plate 51. Day 363 - Metra Station Platform, Chicago, Surrealism Series, No. 40 (digital collage) 


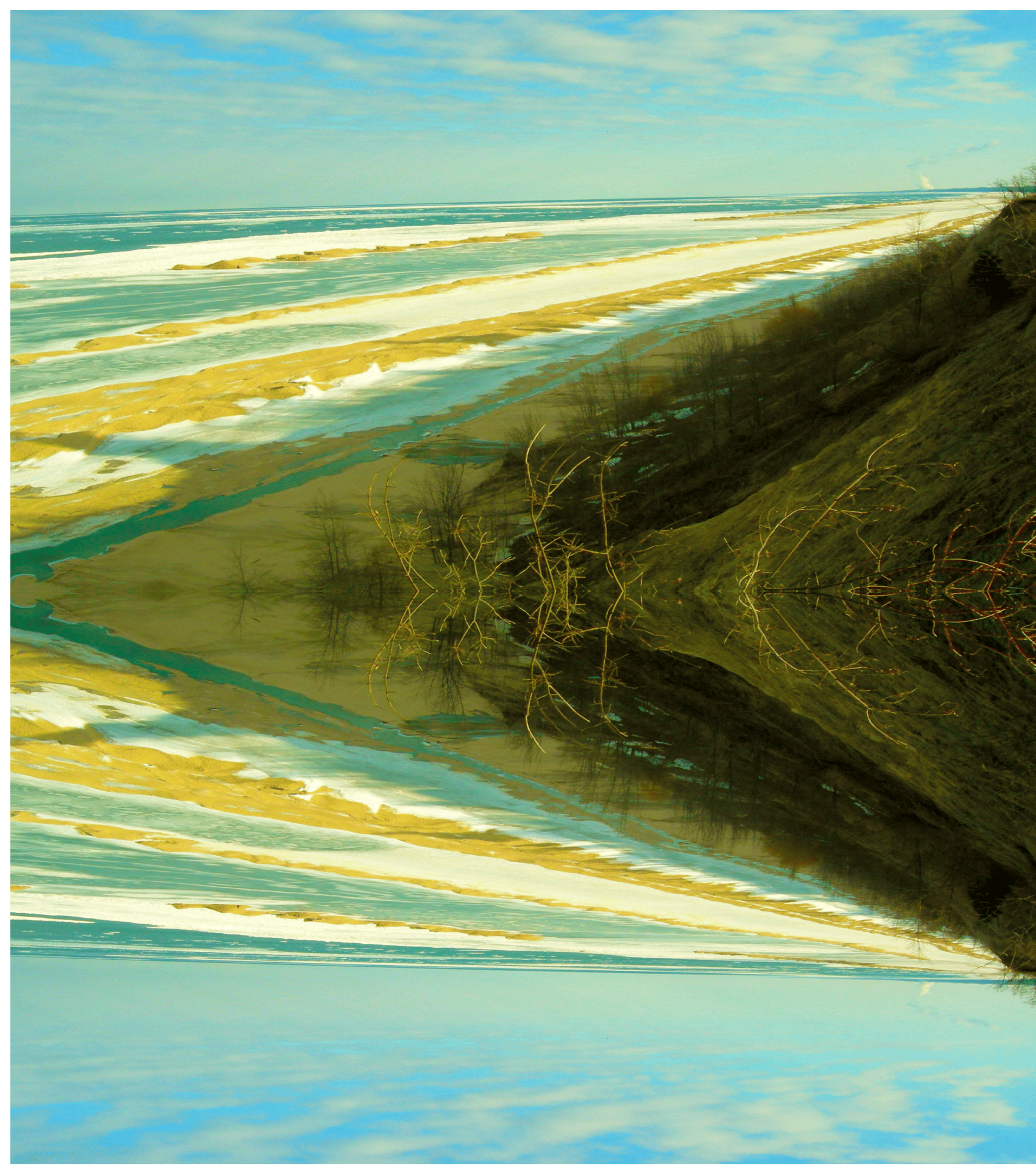

Plate 52. Day 364 — Lake Michigan Shoreline, Surrealism Series, No. 41 (digital collage) 


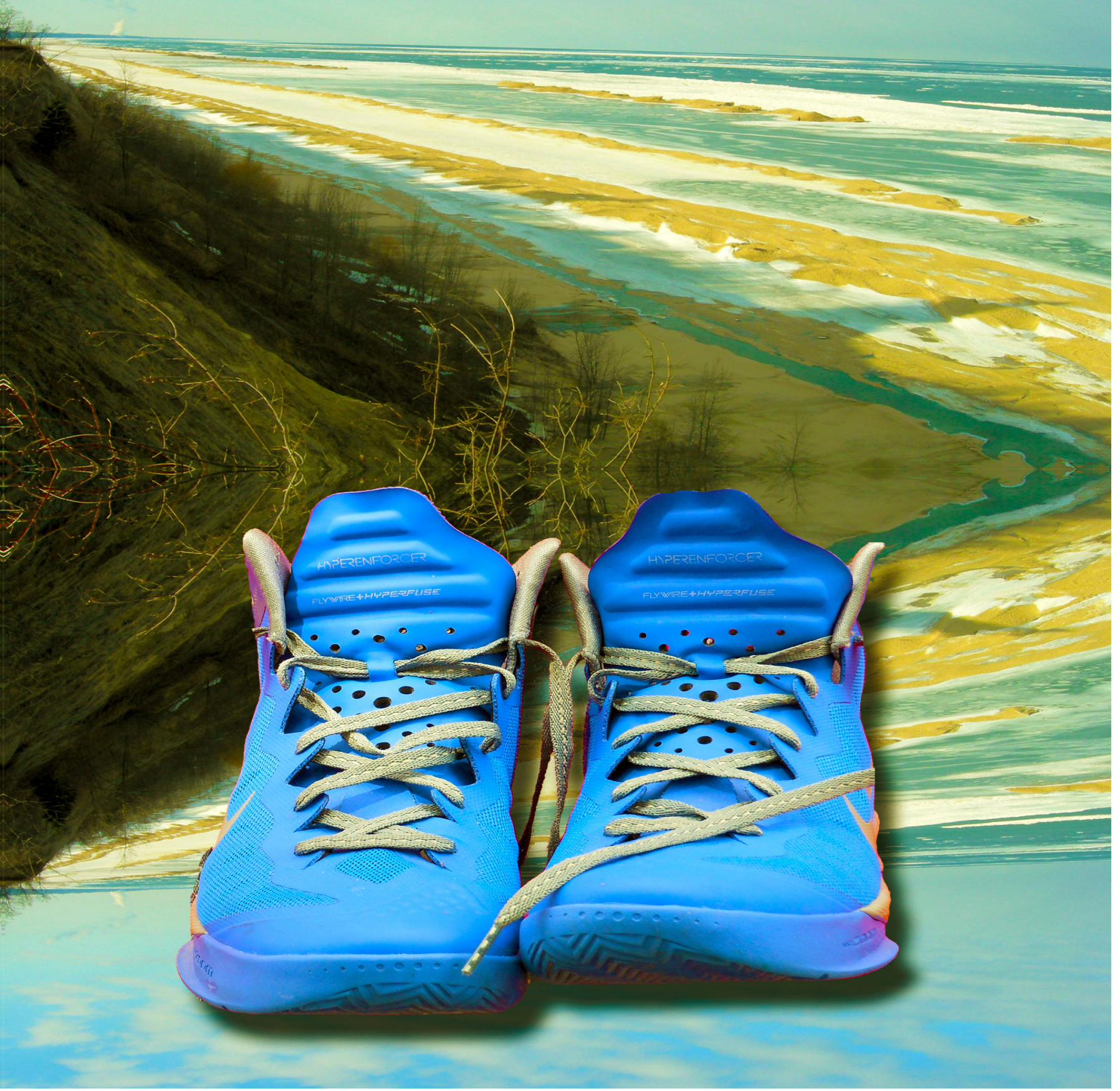




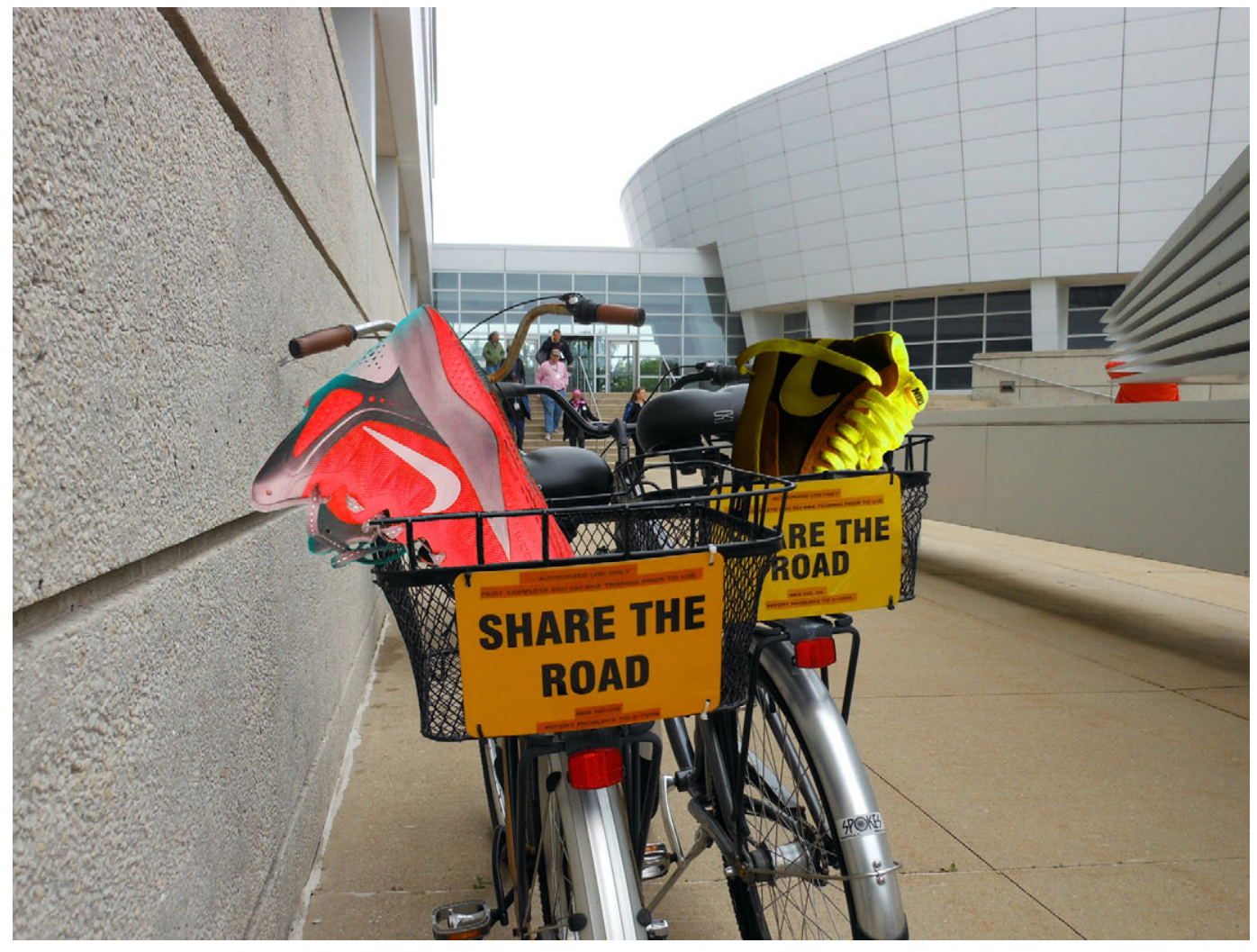

66 


\section{NOTES ON SOURCES FOR THE PLATES}

Plates 1-13, new photos by Hill.

Plate 14, new collage by Hill based on Plate 1.

Plate 15, new parody by Hill of 2009 photo made by Damon Winter of the New York

Times. For Winter's original photograph and related photos, please consult: http://www.nytimes.com/slideshow/2009/01/21/us/20090121BALLS_index. html?_r=0

Plate 16, new parody by Hill of sketch made by Owen Jones from George Moore's Views of the Nile, 1843.

Plate 17, new parody by Hill of undated archived photo from the University of Nebraska-Lincoln depicting UNL scholars Meadows and Methuselah.

Plate 18, new parody by Hill of vintage South Shore Railroad poster.

Plates 19-20, new collages by Hill.

Plates 21-22, new photos by Hill.

Plate 23, new collage by Hill based on an older photo by Hill of the former Snowflake Motel (now demolished), Stevensville, Michigan.

Plate 24, new collage by Hill.

Plates 25, new collage by Hill based a 2006 photo by Hill of St. Joseph's Oratory in Montreal, Canada.

Plate 26, new collage by Hill based on a 2007 photo by Hill of a poppy field in western Ireland.

Plate 28 , new collage by Hill.

Plate 29, new collage by Hill based on portrait triptych made by Hill in 2012.

Plate 30 , new collage by Hill based on B\&W item from a family photo album.

Plate 31 , new collage by Hill based on $B \& W$ vintage photograph album.

Plates 32-33, new collages by Hill.

Plates 34-39, new photos by Hill.

Plates 40-44, new collages by Hill.

Plate 45 , new photo by Hill of two physically interwoven new photos by Hill.

Plates 46-49, new collages by Hill.

Plate 50, new collage incorporating a 2010 photo from Uppsala, Sweden, by Hill.

Plates 51-52, new collages by Hill. 


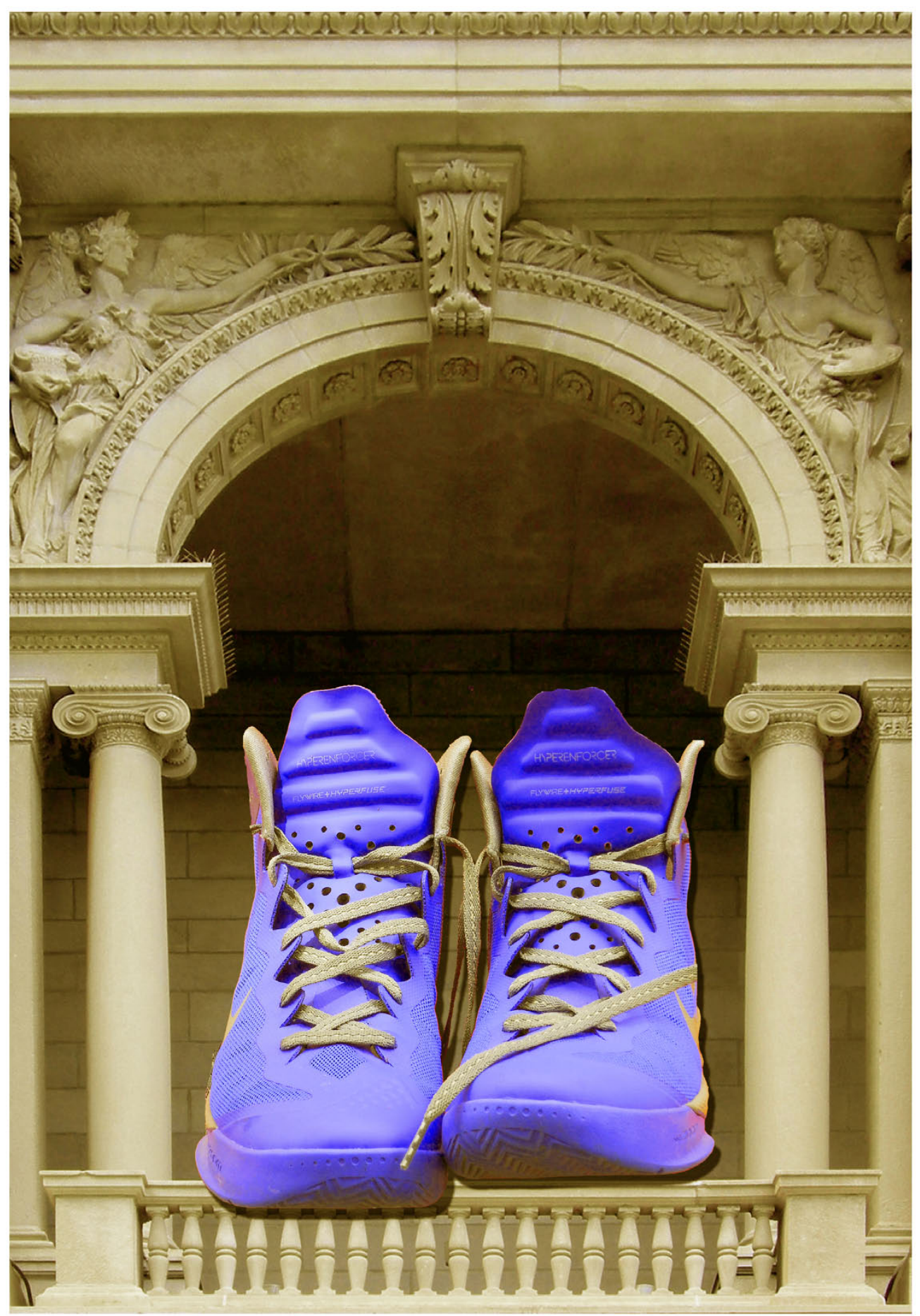


APPENDIX I:

\title{
Lesson Plan: My FaVorite Shoes in Words AND A Picture
}

\author{
Presented at \\ The Art Institute of Chicago \\ 2014 Curriculum Fair
}




\section{The Art Institute of Chicago \\ 2014 Curriculum Fair \\ Thursday, May $9^{\text {th }}, 4-7 \mathrm{pm}$ \\ Lesson Plan}

\section{MY INFORMATION:}

Name: Michael R. Hill

School: University of Nebraska-Lincoln

Subject(s): Expressive Writing; Visual

Interpretation; Social History; Sociology

Grade level(s): High School and above

Email:michaelhilltemporary1@yahoo.c om

\section{BIG IDEA:}

Link visual images of the everyday world of fashion to one's personal experience via photography \& writing. [NB: The male and female student athletes (with whom I currently work almost exclusively) relate instantly and emphatically to the imagery of athletic footwear].

\section{LESSON TITLE:}

"My Favorite Shoes In Words and A

Picture"

\section{DESCRIPTION:}

The selected AIC online artworks together with the images in the instructor's online visual blog demonstrate that something as humble as one's favorite shoes can be visually interesting and provocative.

Students learn to express themselves in pictures and words in terms of fashion elements (i.e., athletic shoes) found in their everyday lives and museum websites.

\section{OBJECTIVES}

- Initiate (i.e., kick start) written expression. This exercise is especially useful when students say "I don't know what to write about."

- See one's personal world as it relates to "art" in museums.

- Actively explore links between "the visual" and "the written."

- Demonstrate connections between "social history", "fashion," "museums," and "everyday life."

STANDARDS: This activity is employed ad hoc to enable students in one-on-one tutorial writing sessions to quickly get down to the business of writing. 


\title{
The Art Institute of Chicago \\ 2014 Curriculum Fair \\ Thursday, May $9^{\text {th }}, 4-7 \mathrm{pm}$ \\ Lesson Plan
}

\begin{abstract}
ART INSTITUTE OF CHICAGO ARTWORK
In our case (out-of-state), physical visits to the AIC are not practical, but virtual visits are easily accommodated.

For example, the following works are displayed on-line at: http://www.artic.edu/aic/collections/

- "Man's Shoes, Grant Park, Chicago." Thomas Frederick Arndt (American). 1991. Gelatin silver print. $29.2 \times 43.8 \mathrm{~cm}$.

- "Pair of Shoes (Formerly Belonging to Queen Victoria, 1819-1901)." Grundy \& Sons (English shoemaking firm). Circa 1850. Leather and silk, satin weave. $23 \times 7 \times 3.5 \mathrm{~cm}$.

- "Spanish Shoes." Irving Penn (American). 1963, printed 1983. Gelatin silver print. $19.9 \times 24.5 \mathrm{~cm}$.

- "Still Life with My Shoe." Marice Tabard (French). 1929. Gelatin silver print. $22.8 \times 16.6 \mathrm{~cm}$

By entering the search term "shoes," many additional examples are readily available.
\end{abstract}




\section{The Art Institute of Chicago 2014 Curriculum Fair \\ Thursday, May $9^{\text {th }}, 4-7 \mathrm{pm}$ \\ Lesson Plan}

\section{GUIDED LOOKING}

- Are the shoes in the selected images "special" or "ordinary"? What makes something "ordinary"? What makes it "special"?

- In what specific ways would the image change if we removed the shoes from the image?

- What do the shoes tell us about the people who wore them?

- What other information do the shoes specifically contribute to the image?

- How crucial are the shoes to the impact of the image?

- Can we substitute other fashion elements (e.g., neckties, handbags) and still obtain the same visual impact? Why or why not?

- What is the difference between seeing a picture of a pair of shoes versus seeing the shoes themselves? What might we learn if we could see the actual shoes?

- Can we tell from the image alone whether these are men's or women's shoes? Why or why not?

- Can we tell from the image alone when the image was made? Why or why not? 


\section{The Art Institute of Chicago \\ 2014 Curriculum Fair \\ Thursday, May ${ }^{\text {th }}, 4-7 \mathrm{pm}$ \\ Lesson Plan}

\section{ACTIVITIES / PROCEDURE}

1) Observe selected works from the AIC website that focus on "shoes." [This activity establishes the fact that "everyday items" such as one's shoes are found displayed/represented in museum settings and are thus defined as culturally important]. http://www.artic.edu/aic/collections/

2) Examine the instructor's visual blog re sneakers/athletic footwear at: www.absence-in-art.tumblr.com [This activity establishes rapport with the instructor and demonstrates the instructor's interest in making visual images based on his own athletic shoes].

3) Make a photograph of your favorite pair of sneakers/athletic shoes. [This component engages students in making non-written, visual images in which they become directly and personally invested].

4) Write a few sentences explaining what makes these your "favorite" shoes.

5) Discuss/review the resulting photo and written work with the instructor with a view to strengthening and sharpening the written component. Students invariably include themes (such as "competition," "look," "experience," "personal choice," "self-image," etc.), even in brief commentaries, that can be pointedly expanded in directions that meet the requirements of larger essay projects and assignments in a variety of humanities classes.

\section{MATERIALS:}

1) The students' favorite sneakers,

2) digital camera,

3) access to computer and word-processor,

4) access to a printer and/or email.
VOCABULARY/GLOSSARY/KEY WORDS:

Shoes, writing, athletic footwear, photography, visual blog, museums, fashion, social history, sociology, visual interpretation, humanities, tutorials 


\section{The Art Institute of Chicago \\ 2014 Curriculum Fair \\ Thursday, May $9^{\text {th }}, 4-7 \mathrm{pm}$ \\ Lesson Plan}

\begin{abstract}
ASSESSMENTS:
The completed project (photo and writing) are not graded but are used as talking points for improving and expanding written work. Students are encouraged to make self-assessments for the purpose of improving the clarity and expressiveness of their writing and to extend the writing to meet the requirements of more specific assignments in a variety of courses in the humanities and social sciences.
\end{abstract}

\section{RESOURCES \& BIBLIOGRAPHY:}

"Arndt, Thomas Frederick." Name search at the Museum of Contemporary Photography website: http://www.mocp.org/detail.php? type $=$ related $\& \mathrm{kv}=6846 \& \mathrm{t}=$ people

Giorgio Riello and Peter McNeil, "Footprints of History." History Today, March 2007 (Vol. 57, No 3), p30-36. [A history of shoes].

Grant Glickson, "At 'Sneakerhead' Fairs, Air Jordans Are Golden." New York Times, April 17, 2014, pp. A1 A3.

"Irving Penn." Wikipedia, the free encyclopedia.

http://en.wikipedia.org/wiki/lrving Penn

Krick, Jessa. "Shoes in The Costume Institute". In Heilbrunn Timeline of Art History. New York: The Metropolitan Museum of Art, 2000-.

http://www.metmuseum.org/toah /hd/shoe/hd_shoe.htm (October 2004)

"Maurice Tabard." Wikipedia, the free encyclopedia.

http://en.wikipedia.org/wiki/Mauri ce_Tabard

"NIKE, Inc. - History \& Heritage." http://nikeinc.com/pages/historyheritage 


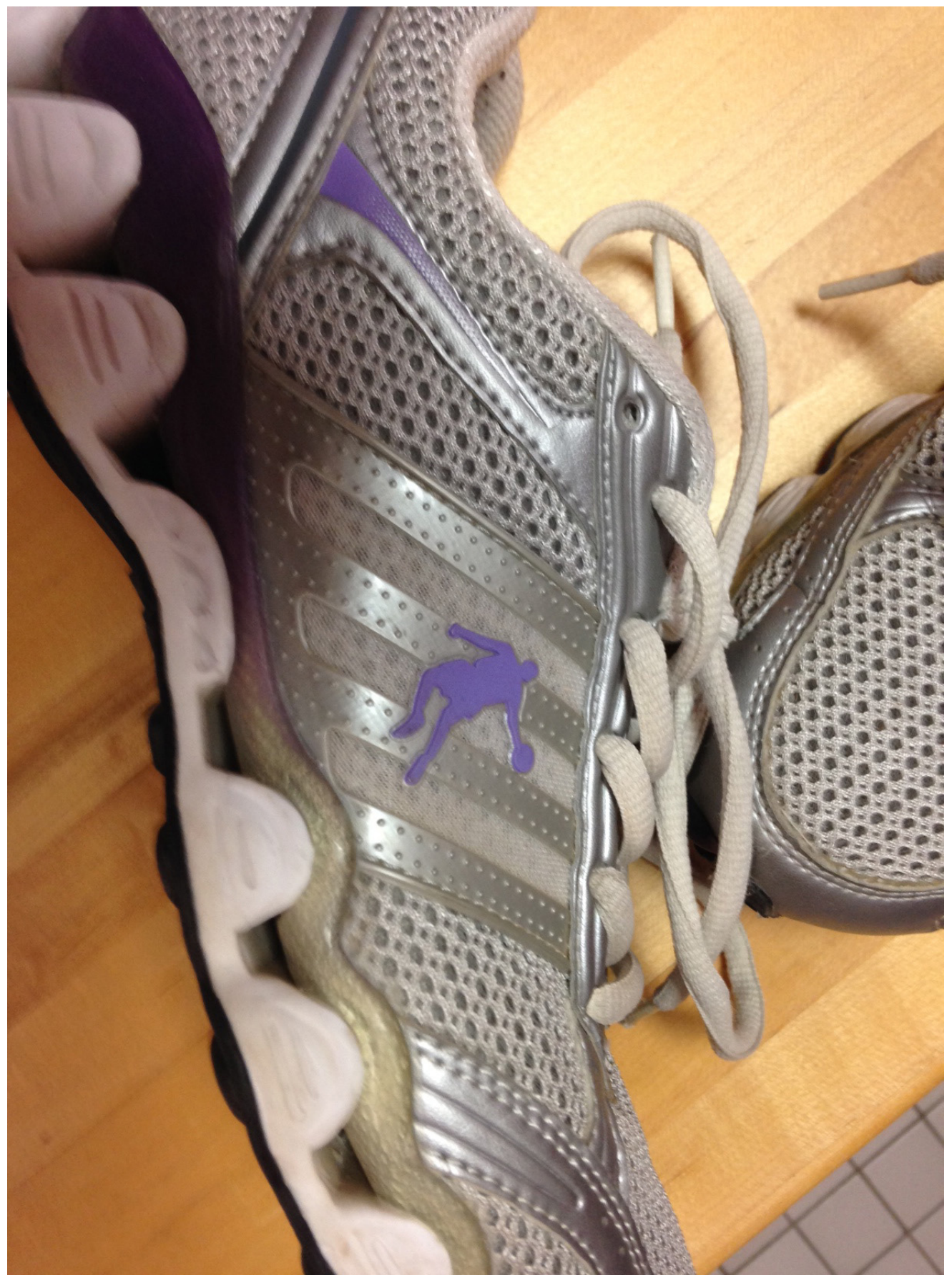

Figure 5. Example Student Photograph 
APPENDIX II:

\section{AN EXEMPLARY STUDENT ESSAY}

\section{"Qjaodan" - My Favorite Sneakers}

This is the only pair of sneakers I have. ${ }^{1}$ My parents bought these for me in my hometown Wuhan, China before I came to America. I have had them for about 7 years. My dad is a P.E. teacher and a former professional basketball player. He read online that Nebraskans love sports, especially football. So he encouraged me to take sports gears to America, hoping that I could take good care of my health by working out more. I still can remember the day my parents and I shopped the shoes, as if it just happened yesterday. As you can see in the picture, the brand of the shoes spells "Qiaodan", which is the Chinese spelling of Jordan. At that time, almost everyone knew that Michael Jordan was a famous American basketball player. The logo of the shoes is Jordan playing basketball. To be honest, I didn't like the shoes in the first place. Anyway, I didn't care about sneakers at all because I was never a big fan of sports. For the sake of satisfying my parents' hope, I brought them to America. But now they became my favorite sneakers because they are light weighted, functional, durable, and nice looking. They never failed me. They are my best friends in the gym. I never thought of replacing them as long as they are in good shape. The best part is, the shoes only cost 15 dollars, which is well worth the money. I love my little blue Jordan shoes!

\footnotetext{
${ }^{1}$ See Figure 4 (above, page 7) and Figure 5 (opposite, page 76), for the student's photos.
} 


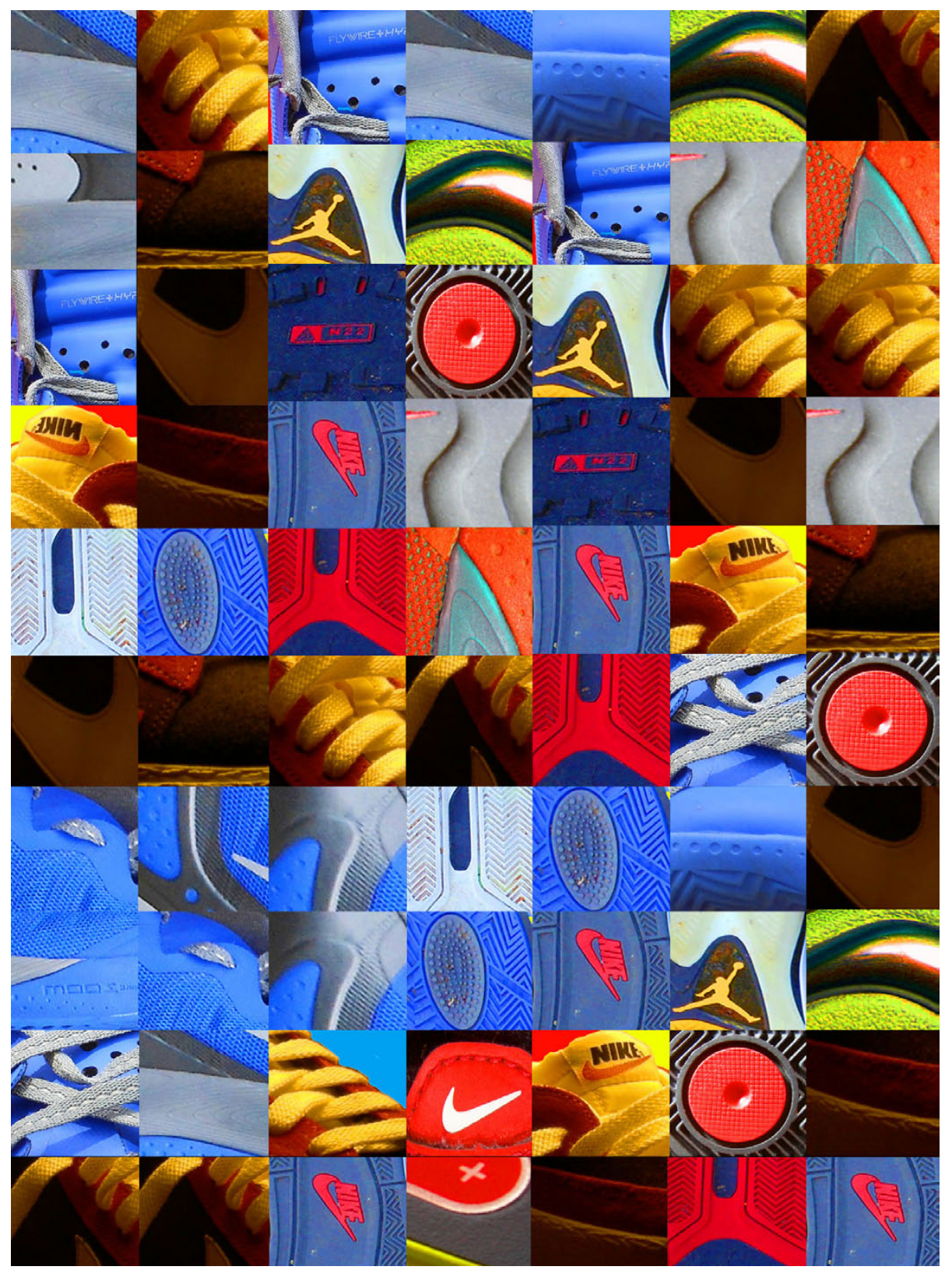




\section{ABOUT THE CONTRIBUTORS}

Georgina VAlVerde is currently Assistant Director of Teacher Programs at the Art Institute of Chicago (AIC). She is an interdisciplinary artist and educator whose work encompasses sculpture, performance, writing, and critical pedagogy. She holds an MFA from the University of Illinois at Chicago and a BFA in Painting and Printmaking and BA in Modern Languages from James Madison University, Virginia. She has exhibited her work widely including in Chicago at the Museum of Contemporary Art, the Hyde Park Art Center, and the National Museum of Mexican Art. She is also the founder of the Society of Smallness, a collaborative platform exploring the potential for small actions to generate creative opportunities for everyone. Most recently, Ms. Valverde led the design and construction of Caracol, one of

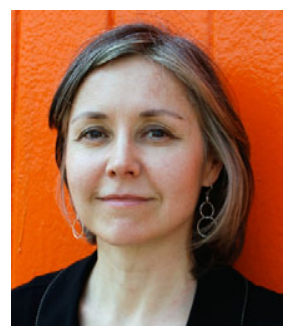
five community-designed spaces along the Burnham Wildlife Corridor in Chicago. Completing nearly ten years at the AIC, Ms. Valverde will pursue her own work focusing on art, cognition, and language - starting in November 2016.

Michael R. HiLL is an interdisciplinary scholar with a BA from the University of Nebraska at Omaha (UNO). His MA and two PhDs (geography, 1982; sociology, 1989) are from the University of Nebraska-Lincoln (UNL). His teaching posts include: lowa State University, Albion College, University of Minnesota Duluth, University of Indiana South Bend, UNO, UNL, and the University of Notre Dame. Hill tutored in the UNL Department of Athletics from 2005 to 2015. His specialties include archival research, human spatial behavior, visual sociology, and the theories, methods, and histories of the social sciences (especially the work of Harriet Martineau). Hill is a co-founder of the Harriet Martineau Sociological Society, the founding editor of Sociological Origins, and the author/editor of a dozen scholarly books. He

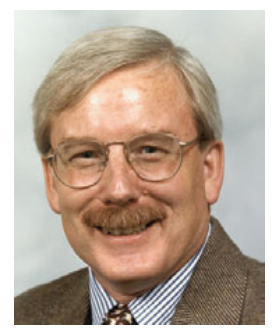
received the Distinguished Scholarly Career Award from the ASA History of Sociology Section in 2003. Hill is now a writer/researcher at D\&H Sociologists and a docent in the Krasl Art Center's K-12 Understanding Art Program. He lives in St. Joseph, Michigan, with his life-partner, Mary Jo Deegan. 


\section{Previous Zea Books by Michael R. Hill}

The Bureau of Sociological Research at the University of Nebraska-Lincoln: A Brief History, 1964-2014. Lincoln: Zea Books, University of NebraskaLincoln Libraries, 2016.

Dogs \& Society: Anglo-American Sociological Perspectives (1865-1934). Edited by Michael R. Hill and Mary Jo Deegan. Lincoln: Zea Books, University of Nebraska-Lincoln Libraries, 2016.

Space, Region \& Society: Geographical Essays in Honor of Robert H. Stoddard. Edited by Michael R. Hill. Lincoln: Zea Books, University of NebraskaLincoln Libraries, 2016.

\section{All Zea Books are available as free PDF downloads via the} University of Nebraska-Lincoln Digital Commons

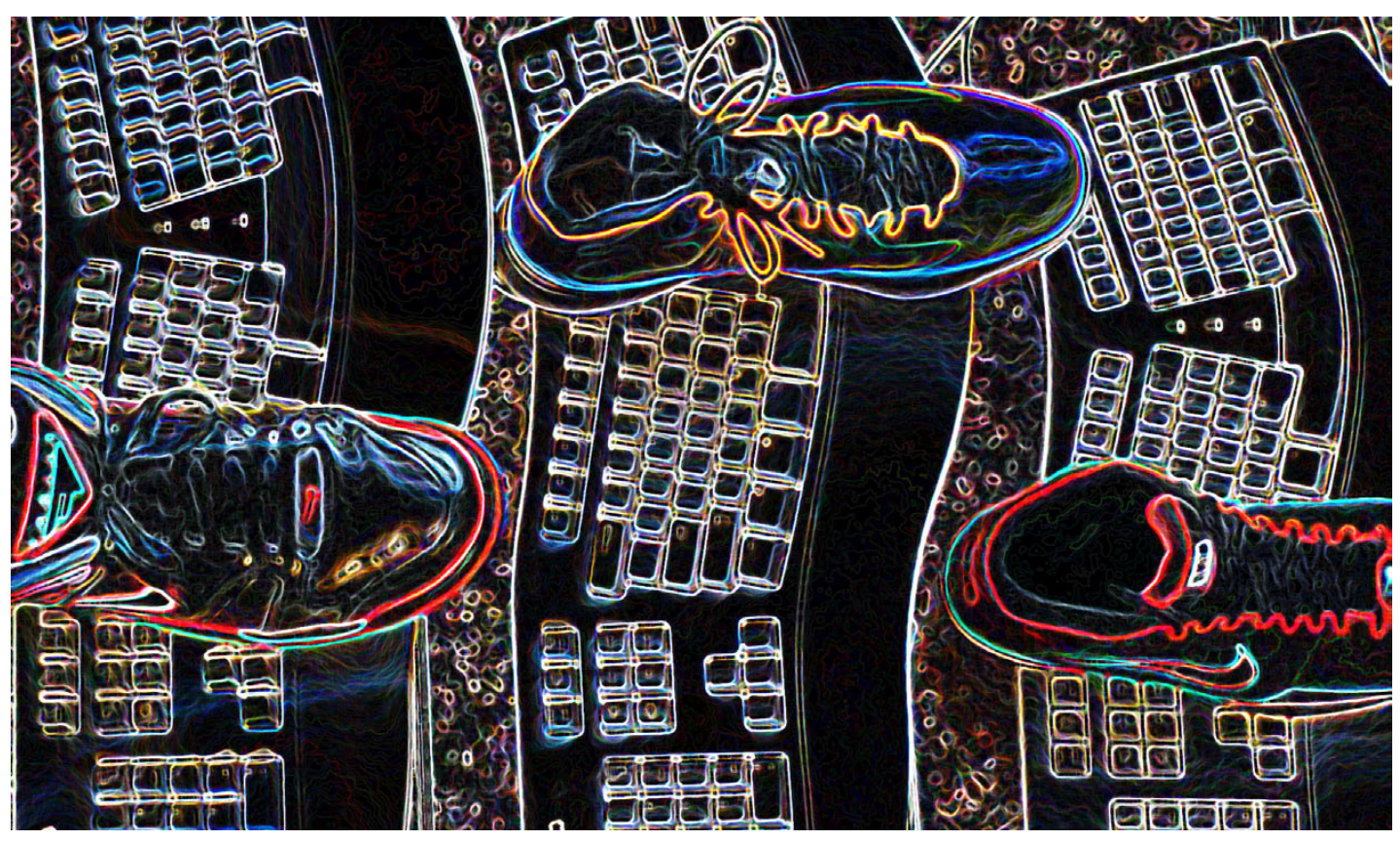




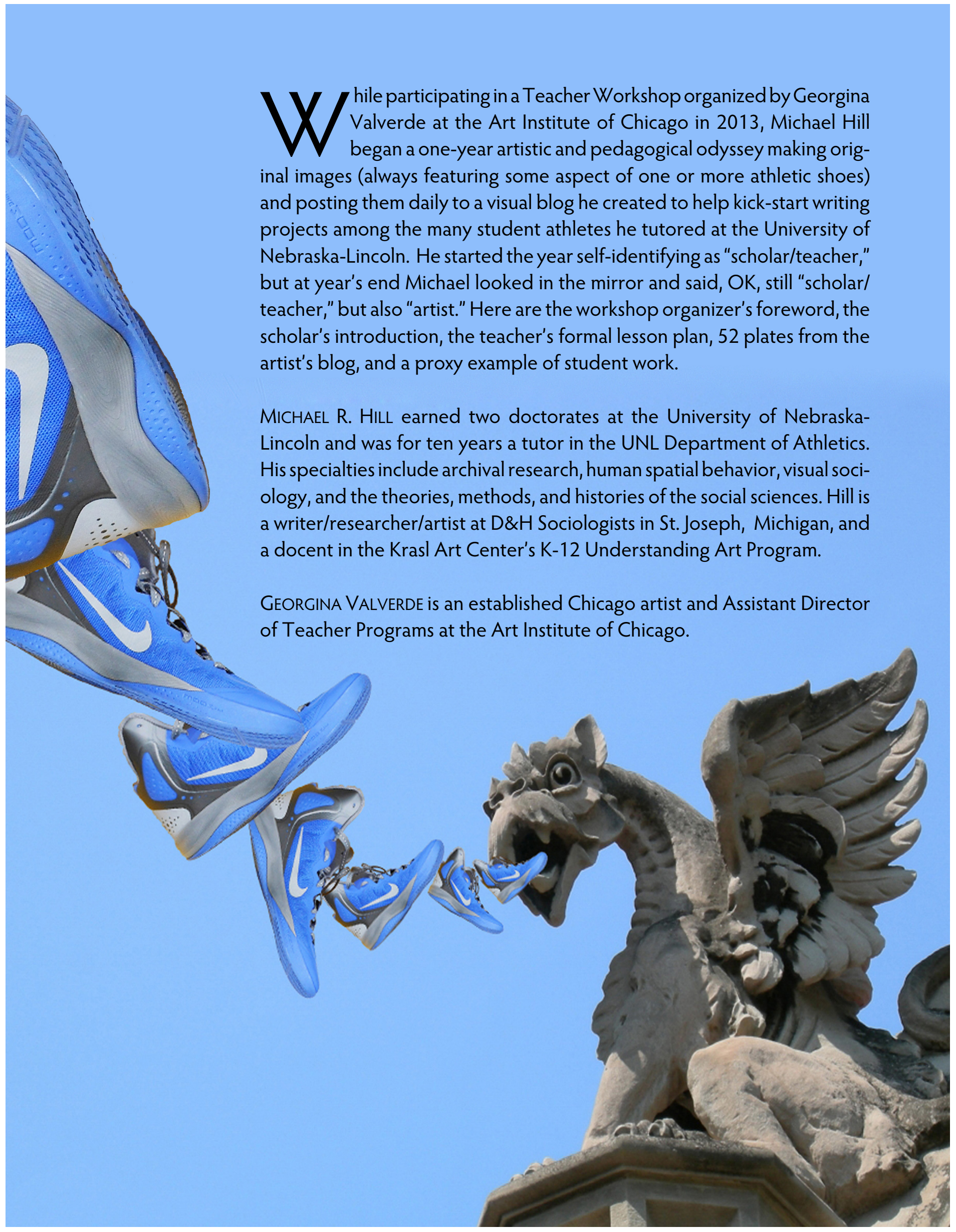

